\title{
Archeological Test Excavations at 41WM543 on FM 734, the Parmer Lane Extension, Williamson County, Texas
}

Barbara J. Hickman

Follow this and additional works at: https://scholarworks.sfasu.edu/ita

Part of the American Material Culture Commons, Archaeological Anthropology Commons, Environmental Studies Commons, Other American Studies Commons, Other Arts and Humanities Commons, Other History of Art, Architecture, and Archaeology Commons, and the United States History Commons

Tell us how this article helped you.

This Article is brought to you for free and open access by the Center for Regional Heritage Research at SFA ScholarWorks. It has been accepted for inclusion in Index of Texas Archaeology: Open Access Gray Literature from the Lone Star State by an authorized editor of SFA ScholarWorks. For more information, please contact cdsscholarworks@sfasu.edu. 


\section{Archeological Test Excavations at 41WM543 on FM 734, the Parmer Lane Extension, Williamson County, Texas}

\section{Licensing Statement}

This is a work produced for the Texas Department of Transportation (TxDOT) by the report producer. TxDOT and the report producer jointly own all rights, title, and interest in and to all intellectual property developed under TXDOT's contract with the report producer. The report may be cited and brief passages from this publication may be reproduced without permission provided that credit is given to both TXDOT and the report producer. Permission to reprint an entire chapter, section, figures or tables must be obtained in advance from either the Supervisor of the Archeological Studies Branch, Environmental Affairs Division, Texas Department of Transportation, 125 East 11th Street, Austin, Texas, 78701 or from the report producer. 


\title{
Archeological Test Excavations at 41 WM543 on FM 734, the Parmer Lane Extension, Williamson County, Texas
}

by Barbara J. Hickman

\author{
With Contributions by
}

Stephanie S. Strickland

April

2000

\section{Environmental Affairs Division Texas Department of Transportation}




\begin{abstract}
A previously recorded site, 41WM543, was re-evaluated by archeologists from the Texas Department of Transportation in connection with the FM 734 ParmerLane extension northwest of A ustin, Texas. The portion of the site within the proposed right-of-way was tested after a burned rock concentration was exposed. Chronology of the open campsite is based on projectile point typology as no datable features were found. The diagnostic projectile points represented a time span of Early Archaic through Late Archaic Periods. The majority of the points were found in only two levels, however. Given the lack of buried features, nofurther work is recommended. The site area within the right-of-way does not meet the criteria for nomination to the National Register of Historic Places (NRHP).
\end{abstract}




\section{Contents}

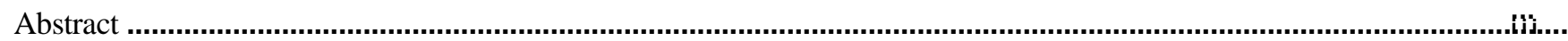

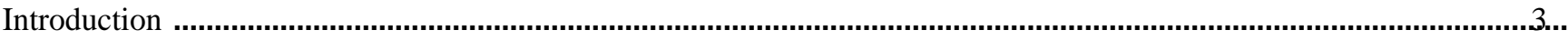

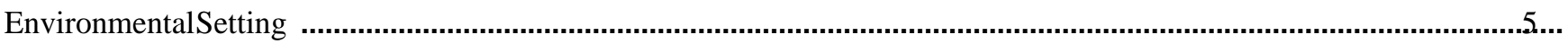

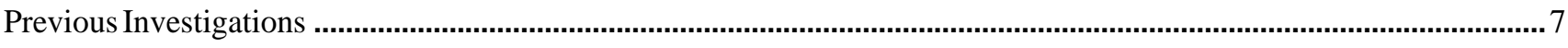

Culture History

Project Methodology

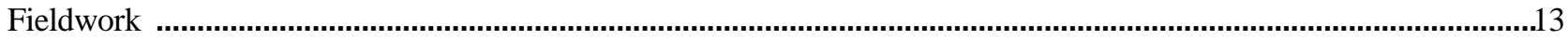

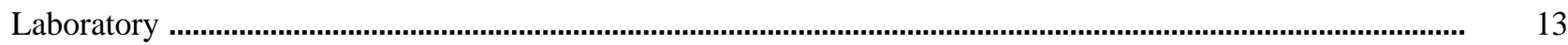

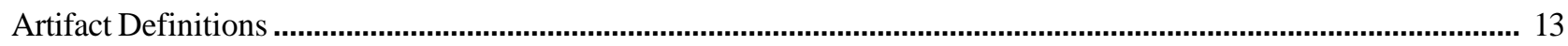

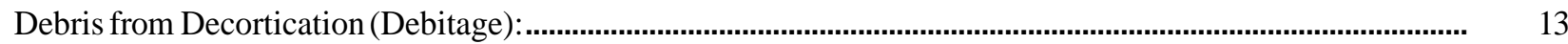

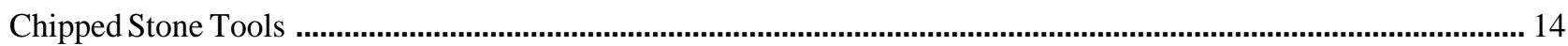

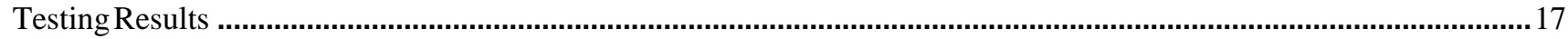

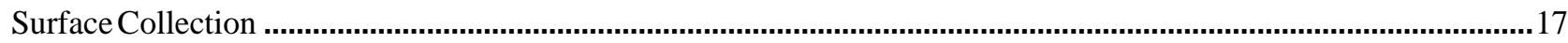

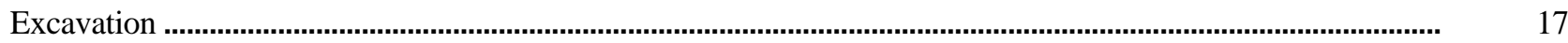

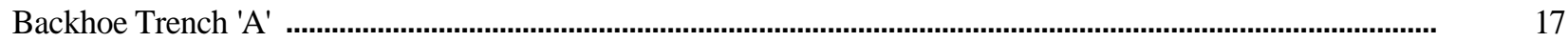

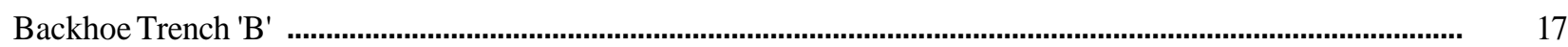

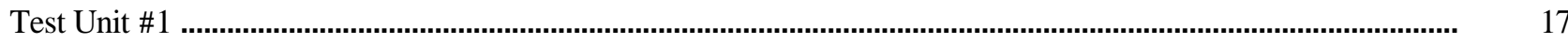

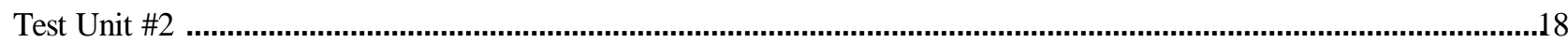

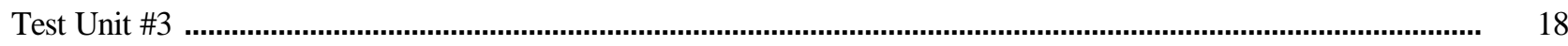

Outside Ash Concentration .................................................................................................................................

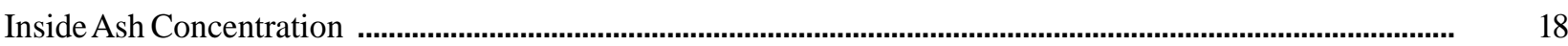

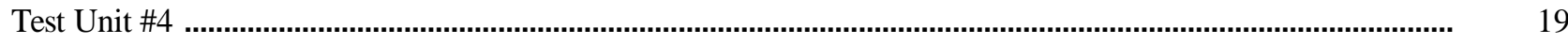

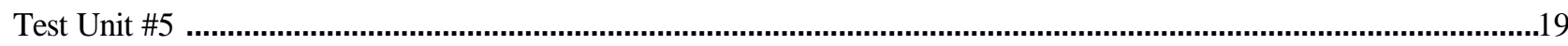

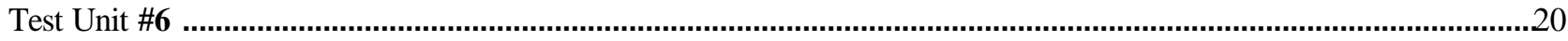

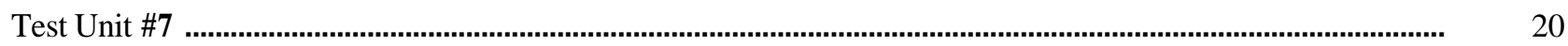

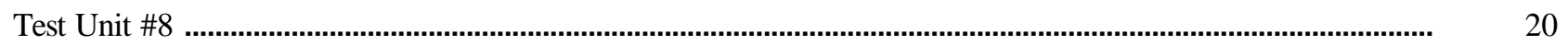

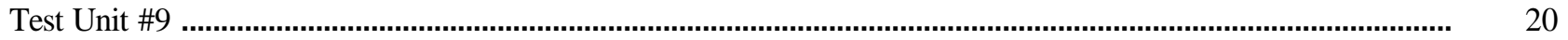

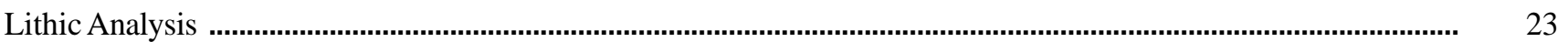

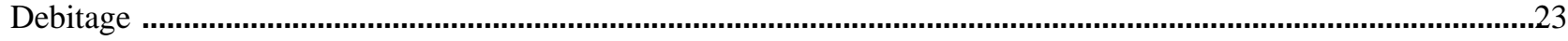

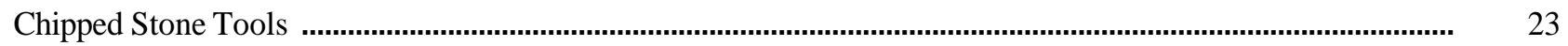

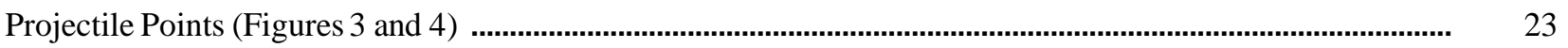

Andice type (1 specimen) ……................................................................................................................... 23

Bulverde type (2 specimens) .................................................................................................................................. 27

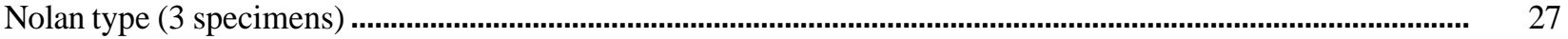

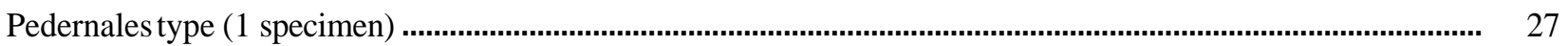




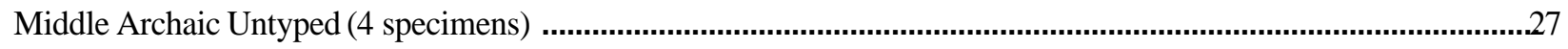

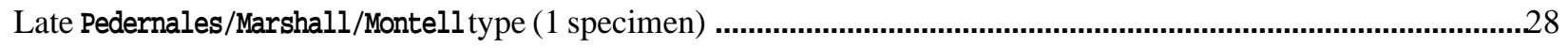

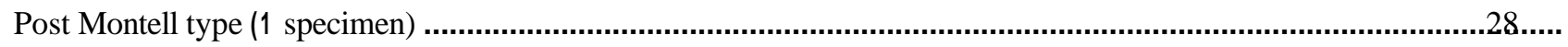

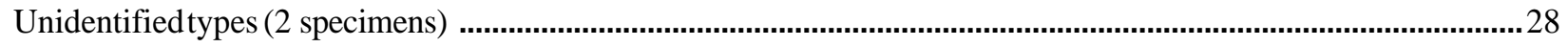

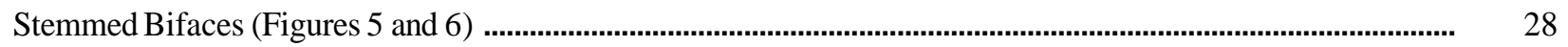

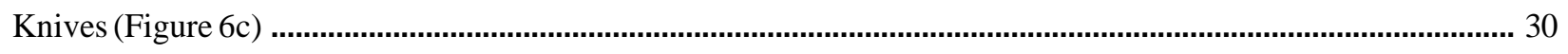

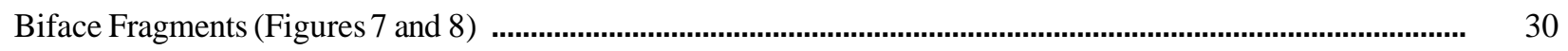

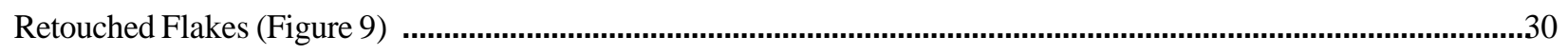

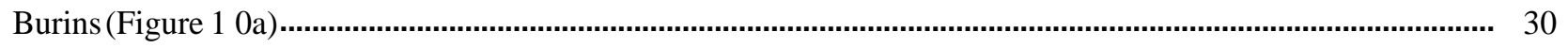

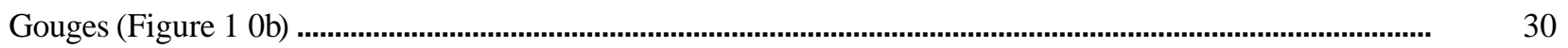

Scrapers (Figure 10c) ….............................................................................................................................

Utilized Blades and Flakes (Figure 10) ...................................................................................................................

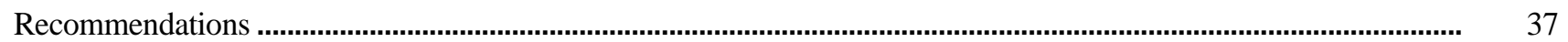

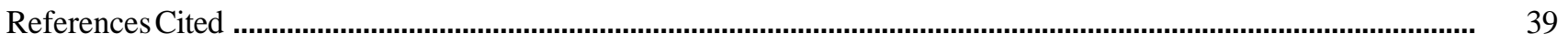

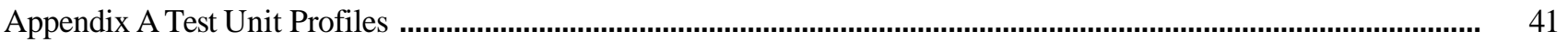

1. Profile of Backhoe Trench 'A', east wall .................................................................................................. 43

2. Profile of Backhoe Trench 'B', east wall.................................................................................................

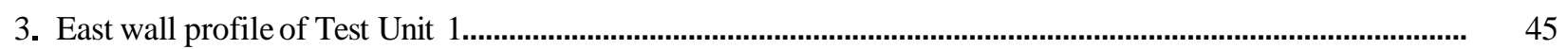

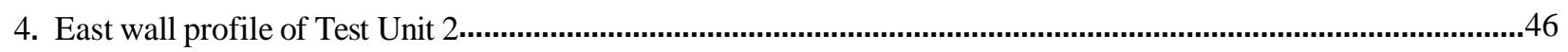

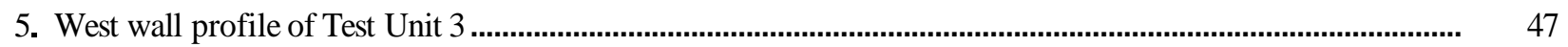

6. East wall profile of Test Unit 3 ......................................................................................................... 48

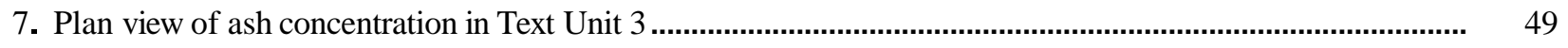

8. East wall profile of Test Unit 4............................................................................................................ 50

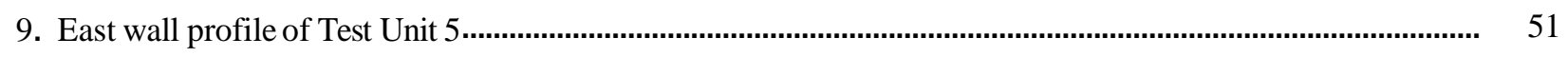

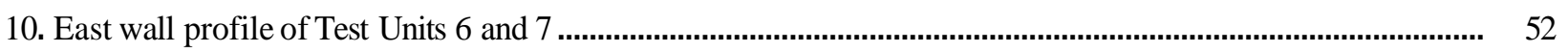

II. East wall profile of Test Units 8 and 9 ...................................................................................................

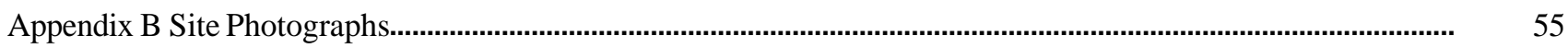

1. Overview of burned rock scatter within the right-of-way before trenching.................................................... 57

2. Site area of 41WM543 outside the FM 734 right-of-way........................................................................ 57

3. Beginning trenching at Backhoe Trench A looking south................................................................................ 58

4. Site area 41 WM543 showing Backhoe Trench B (foreground) ........................................................................ 59

5. East wall profile of Backhoe Trench A, showing ashy concentration.............................................................. 60

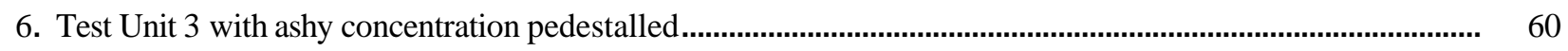

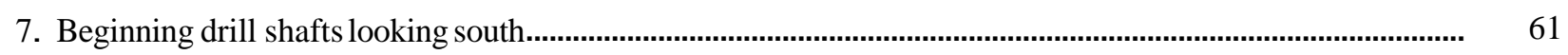

8. Construction of piers for bridge bents, looking north................................................................................ 61 


\section{List OF Figures}

FIGURE 1. Leander. Texas 7.5' series 1987 USGS topographic map 3097-321 ......................................................2

FIGURE 2. Site area of 41 WM543 outside the FM 734 right-of-way ......................................................................... 4

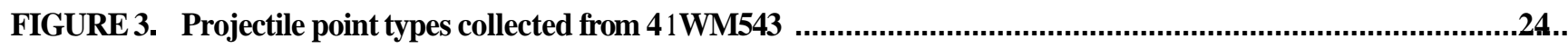

FIGURE 4. Projectile point types collected from 41 WM543 _................................................................................... 25

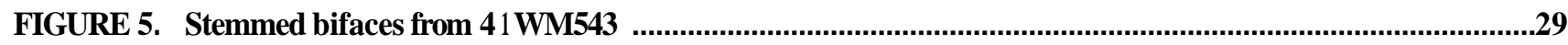

FIGURE 6. Stemmed bifaces and knives from 41 WM543 ..........................................................................

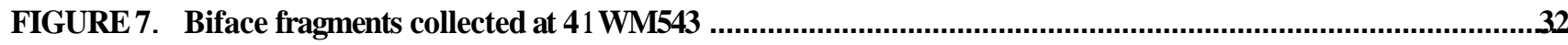

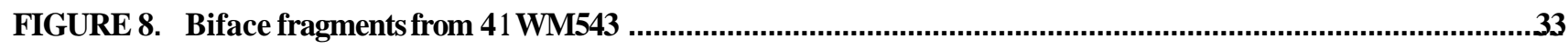

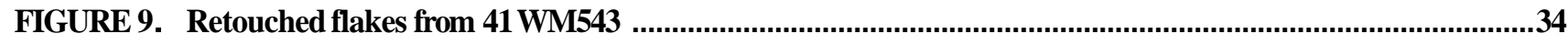

FIGURE 10. Miscellaneoustools from 41 WM543 ….......................................................................................... 35 


\section{LIST OF TABLES}

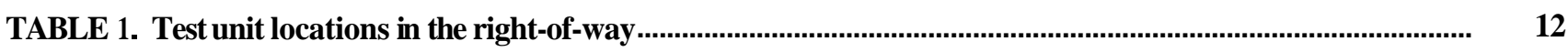

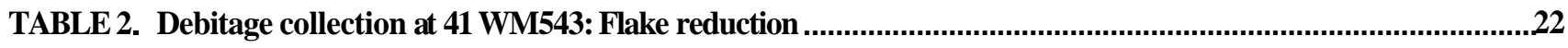

TABLE 3. Tools collected at 41 WM543 ........................................................................................................ 26

TABLE 4. Blades and other chipping debris from 41 WM543 ..................................................................................... 36

TABLE 5. Utilization scars on flakes .................................................................................................................... 37 
This Page Redacted Per THC Policy 


\section{INTRODUCTION}

In December, 1991 and January, 1992 archeologists from the TxDOT Environmental Section conducted a cultural resource inventory of the proposed extension of FM 734 (Parmer Lane) from RM 620 to FM 1431 in southwestern Williamson County (Figure 1). The extension of Parmer Lane was planned on $4.3 \mathrm{mi}$. $(2.67 \mathbf{~ k m})$ of new location with a right-of-way (ROW) measuring $200 \mathrm{ft} .(60.9 \mathrm{~m})$ wide to continue the existing segment of FM 734 fi-om Loop 275 to RM 620. A total of eight historic and prehistoric sites were located in the project area and evaluated. Five sites were previously recorded, namely, 41WM543, 41WM559, 41WM565, 41WM566, and 41WM713; three additional prehistoric sites, recorded as 41WM774, 41WM775, and $41 \mathrm{WM} 776$, were identified in the course of thesurvey. None of the sites were recommended as eligible to the National Register of Historic Places (NRHP) based on the slight potential for buried cultural deposits within the proposed right-of-way.

On 2 September 1992, the TxDOT Austin District notified the Environmental Section archeology branch that buried cultural materials were uncovered during construction north of South Brushy Creek. All construction was immediately halted in the area of discovery. Upon inspecting the specified location on 3 September 1992, the supervising TxDOT archeologist observed two exposures of fire-cracked rock within the site limits of the previously recorded 41WM543. One concentration spanned approximately $7 \mathrm{~m}$ in diameter, while the second concentration measured roughly $3 \mathrm{~m}$ across. The burned limestone was uncovered when the bulldozer cleared trees for ROW fence construction on the western limits of the project, disturbing perhaps the top $10 \mathrm{~cm}$ of the existing ground surface deposit. The concentrations were seen in the ruts left by heavy equipment crossing the eastern portion of 41WM543.

TxDOT evaluated site 41WM543, a previously recorded site, during the archeological survey in January, 1992. The open campsite offered a scatter of lithics and fire-cracked rock spread over a large area of the first terrace, perhaps $600 \mathrm{~m}$ (1968 ft.) in length east to west. Located on the north bank of South Brushy Creek, only the eastern edge of the site was identified within the staked right-of-way. Shovel tests within the project boundaries produced one flake, with no concrete evidence that the site was more than a surface manifestation. No further work was recommended, with the standard stipulation that if cultural materials were discovered during construction, archeologists from TxDOT would return to the site for additional investigation.

After the on-site inspection of the burned rock concentrations, the TxDOT archeologist devised a testing plan to determine site significance of the buried cultural deposit at 41WM543 and to ascertain the site's horizontal and vertical limits within the Parmer Lane ROW (Figure 2). Verbal approval for the testing program was obtained on 3 September 1992 at a meeting with the Texas HistoricalCommission Department of A ntiquities Protection (THC-DAP). Copies of the plan were submitted to the Texas Historical Commission (THC), the Federal Highway Administration (FHWA), and the Advisory Council for Historic Preservation (ACHP). 


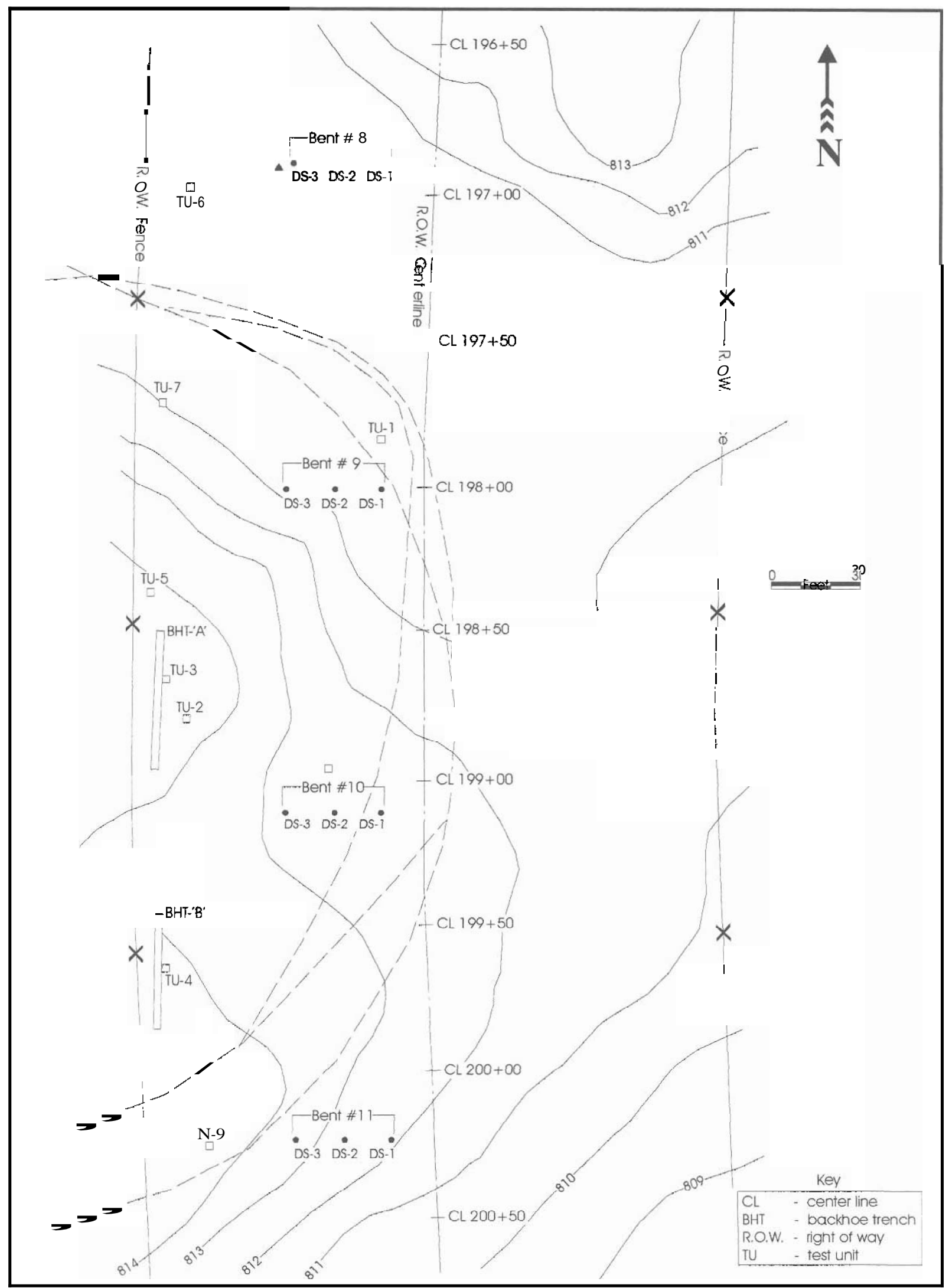

FIGURE 2. Site area of 41W M 543 outside the FM 734 right-of-way 


\section{Environmental Setting}

The project crosscuts through gently rolling uplands of range lands and hills drained by Brushy Creek and its tributaries. The area is included in the Jollyville Plateau, which is a smaller division of the Lampasas Cut Plain in the Texas hill country (Gamer and Young 1976). Elevation ranges from $810 \mathrm{ft}$. to $910 \mathrm{ft}$. AMSL within the right-ofway. Drainages crossed by the project include Davis Spring Branch, South Brushy Creek, and several unnamed lower order ephemeral streams.

Most of the project area has a surface geology of Edwards formation, but close to South Brushy Creek are bands of Walnut formation and Comanche Peak formation. All are associated with the Fredericksburg Group of the Lower Cretaceous System. Gray to black nodules of chert are present in the Edwards formation limestone deposits. Within the South Brushy Creek floodplain, the surface is covered with Recent era alluvium.

Generally the soils in the project area are dark brown to very dark grayish brown calcareous clay loams which are deep but well drained. The soil is quite rocky, and soil deposited over the indurated and fragmented limestone and dolomitic limestone bedrock is shallower away from the creeks. The soil survey (Werchan and Coker 1983: 49; sheet 73 ) shows Sunev silty clay loam on $1 \%$ to $3 \%$ slopes along South Brushy Creek at the location of site 41WM543. Sunev soils are present often in long, narrow bands on stream terraces. The A horizon thickness averages 9 in. to 18 in. $(22 \mathrm{~cm}$ to $45 \mathrm{~cm})$. Sunev loam is a soil association representative of the clay loam vegetational range.

The Soil Survey of Williamson County (Werchan and Coker 1983) describes the plant communities found according to soil associations in the region. Common Texas Grasses (Gould 1978) contains descriptions of the prairie grasses, while information regarding forb species is derived in part from Wildflowers of the Texas Hill Countrv (Enquist 1987).

The clay loam range, a true prairie, is dominated by little bluestem (Schizachyrium scopariurn) with yellow Indian grass (Sorghastrurn nutans), big bluestem (Andropogon glomeratus), tall dropseed (Suorobolus asper) Silver bluestem (Bothriochloa saccharoides), sideoats grama (Bouteloua curtipendula), buffalograss (Buchloe dactyloides), perennial threeawn (Aristida sp.), and Texas wintergrass (Stipa leucotricha). Forbs of the clay loam range include sensitive briar (Schrankia sp.), bush sunflower (Simsiacalva), bundleflower(Desmanthus illinoensis),Englemann daisy (Engelmanniapinnatifida), and prickly pear cactus (Opuntiasp.). The trees in the range are usually Ashe juniper (Juniperus ashei), agarita (Berberis trifoliolata), and persimmon (Diospyrossp.). Thus the project area is characteristically an oak savannah typical of Blair's (1950) Balconian biotic province, with a significant grassland component, particularlyon overgrazed lands.

Primarily the land is used for livestock grazing south of South Brushy Creek. Deer hunting in the juniper thickets north of Brushy Creek has left numerous modem hunting stands and winding two-track roads which have altered the landscape. In the late nineteenth and early twentieth centuries, ranching and railroad activities resulted in some settlement near the alignment of presentday RM 620. Commercial development in northwest Austin has expanded into the Cedar Park community, with subdivisions planned for the Davis Spring area near RM 620 and Breakaway Park south of FM 1431 when Parmer Lane is completed. 


\section{Previous Investigations}

Site 41WM543 was originally recorded in January, 1984 by the Texas Department of Water Resources (TDWR). Daniel E. Fox and W. Hayden Whitsett conducted archeological surveys along South Brushy Creek in 1981 and 1984 for proposed wastewater improvements to the city of Cedar Park. Plans for a wastewater treatment plant and an outfall line 3 miles (4.8 km) in length necessitated a 900 -acre (365 ha) inventory. Fox and Whitsett recorded 19 prehistoric and historic archeological sites on both banks of the creek, including 41WM439-41WM441, 41 WM444-41WM450, and 41WM543-41WM545.

The TDWR archeologistsassessed 41WM543 as "a broad, thin scatter of chipped stone and some burned limestone fragments" with a distinct dispersion of late nineteenth - early twentieth century residential artifacts restricted to the western end of the site (Fox and Whitsett 1984:17). The ceramic, glass, and metal pieces were ascribed to the period circa 1890 to 1920; the investigators believed that a tenant frame building had once stood in the field but no foundation remained.

The long, narrow lithic scatter was located along the terrace of the north bank of South Brushy Creek within a field previously cleared and plowed. No diagnostic prehistoric artifacts were observed. Fox and Whitsett (1984:17) characterized 41WM543 as "thoroughly disturbed by cultivation and erosion" and recommended no further work at the site given the prior disturbance. The site was regarded as not eligible to the National Register of Historic Places (Fox and Whitsett 1984:21).

In February, 1986 Laurel Smyth and John Jameson of Espey-Huston \& Associates revisited 41WM543 for the Brushy Creek WCID utility easement survey. Smyth and Jameson echoed the conclusions of Fox and Whitsett. They characterized the site as "a thin lithic scatter with historic materials" restricted to the surface. Less than 5\% of the site was estimated to remain intact due to extensive erosion (Smyth and Jameson 1986). The plowed field was keep as the site boundaries. No diagnostic prehistoric artifacts or cultural features were found. The archeologists reported finding only an unidentifiable projectile point fragment and chipped stone in the plowed field. EspeyHuston recommended no further work, and 41WM543 was considered not eligible to the National Register of Historic Places.

Both the TDWR survey and the Espey-Huston survey involved project areas which extended east of the plowed field along the creek, but neither group seems to have extended the site limits of 41WM543 beyond the eastern edge of the field towards 41WM544. The field was lined to the east by a grove of trees which may have obscured the continued surface scatter along the river bend.

Archeologistsfrom the Texas Department of Transportation reevaluated 41WM543 in the course of surveying the proposed extension of FM 734 (Parmer Lane) from RM 620 to FM 1431. Information obtained during the project file search indicated that the Parmer Lane new location right-of-way would cross South Brushy Creek in close proximity to 41WM543 and 41WM544. The right-of-way staking in fact crossed the north creek bank through the eastern site limits of 41 WM543. The field outside the highway right-of-way was indeed strewn with lithic debris, fire-cracked rock, and tools; inside the project ROW there was a sparse scatter of lithic material. No diagnostic artifacts were found within the project.

A total of seven shovel tests were dug among the trees between Sta. 200+00 and Sta. 198+00inside the proposed ROW, and only one flake was recovered from one of the shovel tests. The shovel test results indicated an absence of burned rock in the clay loam fill, albeit an abundance of bedrock limestone fragments subsurface. Based on these discouraging results, and the assessments of previous archeologists, the site was considered to have little potential for subsurface cultural deposition. No further work was recommended once again for 41WM543. 


\section{Culture History BY Stephanie Stoermer Strickland}

At least five major schemes of cultural classification and chronology were formulated for Central Texas between 1929 and 1954. The first major modem synthesis of the Central Texas region was proposed by Suhm, Kreiger, and Jelks (1954:99-117); since the mid-1960s, however, several revised cultural chronologies have been proposed. The chronology presented here follows the synthesis presented by Prewitt $(1981,1983)$.

Four major stages of development are recognized in Central Texas: Paleoindian (11000 B.P. to 8500 B.P.); Archaic (8500 B.P. to 1200 B.P.); N eoarchaic/L ate Prehistoric (1200 B.P. to 200 B.P.); and Historic (after 200 B.P.).

The term Paleoindian is applied to the late Pleistocene-earlyHolocene aboriginal cultures whose subsistence strategies were dominated by the exploitation of large game animals rather than a more generalized, broad-based hunting and gathering economy. Available evidence indicates that humans were present in Central Texas and neighboring regions by the end of the Pleistocene.

During the Paleoindian period, projectile point styles from several areas occur in Central Texas, a trend that continues throughout prehistory. Lithic styles associated with the big-game hunting traditions of the west including Clovis and Plainview, Meserve types representing southeastern woodland adaptations, as well as Scottsbluff types from the transitional zone between the western grasslands and the eastern woodlands have all been reported in Central Texas.

The lack of well-defined, stratified Paleoindian sites within Central Texas as whole, coupled with meager information about actual resource availability precludes definite conclusions about the occurrence of such diverse cultural markers. The possibility exists that certain areas of Central Texas may have been part of an established seasonal round for different Paleoindian groups and were never continuously inhabited by any particular group.

The Archaic is the perhaps the most thoroughly examined stage of cultural development in Central Texas. As used here, the term "A rchaic" refers to the long-lived cultural stage characterized by hunting and foraging. Tools and faunal remains from the Paleoindian occupation levels at the Wilson-Leonard site in Williamson County and Horn Shelter No. 2 in Bosque County suggest that the shift to a subsistence economy geared primarily to foraging began prior to the Archaic.
A generalized subsistence economy that emphasized foraging and collecting is suggested for the Early Archaic (8500 B.P.-4600 B.P.). However, the distinction between the late Paleoindian and early Archaic occupations is problematic and blurred.

Prewitt (1981:77) delineates and describes the Circleville phase (8500-7000 B.P.), the first phase of the Early Archaic in Central Texas. The Circleville phase is followed by the relatively localized San Geronimo phase (7000 B.P.-6000 B.P.), the Jarrell phase (6100 B.P.-5100 B.P.) and the somewhat short-lived Oakalla phase (5100 B.P.-4600 B.P.). Like the San Geronimo phase, both the Jarrell phase and the Oakalla phase appear to be relatively localized cultural manifestations in Central Texas.

Burned rock middens (accumulations of burned limestone fragments) associated with the intensive processing of vegetal foodstuffs (primarily mast) make their initial appearance during the Oakalla phase and seem to increase in intensity and use in the succeeding Clear Fork phase (Prewitt 1981:79). A strong possibility exists, however, that many middens represent trash piles accrued by hearth cleaning.

The Clear Fork phase (4600 B .P.4000) B.P.) is the first phase of the Middle Archaic. Prewitt (1981:79) notes that along with the apparent trend towards specialization in plant food processing evidenced by the increase in burned rock middens during the Clear Fork phase, the ratio of projectile points to other tools increases, suggesting that a balance is achieved between hunting and gathering. Site frequency also increases during the Clear Fork phase, suggesting a rise in population levels because of more effective subsistence strategies. This trend continues through the Marshall Ford phase (4000 B.P.-3400 B.P.) and peaks during the Round Rock phase (3500 B.P.-2600 B.P.).

Along the Balcones Escarpment, the strong reliance upon acorns and other vegetal resources, as evidenced by burned rock middens and grinding stones, continues through the Round Rock phase and the San Marcos phase (2600 B.P.-2250 B.P.), the terminal phase of the Middle Archaic. By the end of the Middle Archaic subsistence strategies seem to be equally divided between hunting and gathering. The terminus of the Middle Archaic coincides with the decline of burned rock middens in Central Texas and a concomitant shift in subsistence patterns. The presence of marine shell ornaments at San Marcos phase sites may be indicative of a widening trade sphere and contact with coastal peoples (Prewitt, 1981: 80-8 1). 
The Uvalde phase (2250 B.P.-1800 B.P.) is first phase of the Late Archaic. A disruption or termination of trade with coastal peoples is inferred from the absence of marine shell artifacts. Data is lacking concerning representative features. Diagnostic artifacts of the Uvalde phase are frequently recovered from the upper portions of burned rock middens in Central Texas although the accumulation of these middens had apparently ceased prior to the deposition of the artifacts.

Bison populations may have increased in Central Texas during the Uvalde phase, although a well-balanced subsistence economy based on the exploitation of a variety of resources seems to have developed rather than a strategy heavily dependent on bison procurement.

In the Twin Sisters phase (1800 B.P.- 1400 B.P.), the ratio of projectile points to other tools is quite low, suggesting that intensive gathering may have been emphasized rather than hunting. Prewitt (1983: 218) infers from component frequencies and occurrences that population increases occurred during the Twin Sisters phase and peaked during Driftwood phase (1400 B.P.-1250 B.P.), the terminal phase of the Late Archaic.

The Archaic is followed by a period that has been variously called the Neoamerican, Neoarchaic or Late Prehistoric. Population levels were apparently quite low in Central Texas during the Austin phase (1250 B.P.-650 B.P.) of the Late Prehistoric, although by the Toyah phase (650 B.P.-200 B.P.) aboriginal population levels were again on the rise.

The Austin phase is marked by the appearance of true arrow points rather than atlatl dart points. A slight increase in the importance of hunting is inferred from the increased ratio of projectiles to other tools. The diagnostic arrow point for the Austin phase, the Scallorn, has been identified as the probable cause of death in a number of burials suggesting that there was a marked increased in aggression during the Late Prehistoric.

It has been suggested that the Toyah phase peoples moved out of the Plains and into Central Texas in response to a southward expansion of bison. The basic tool kit of the Toyah phase is apparently derived from the Plains and includes contracting stem arrow points, alternately beveled knives and snub-nosed scrapers. Plain, bone-tempered ceramics (Leon Plain, Doss Redware) are also associated with the Toyah phase. Evidence of incipient agriculture is somewhat problematic.

The north to south spread of the Austin and Toyah phases during the Late Prehistoric foreshadowed major population movements in Central Texas during the Historic stage. Incursions by the Lipan Apache and Wichita during the seventeenth and eighteenth centuries, and by the Comanche in the eighteenth and nineteenth centuries, displaced the "indigenous" Tonkawa in the Central Texas area. Although Suhm (1960:85) suggests that the prehistoric materials associated with the Toyah phase (in its earlier incarnation as the Toyah Focus of the Central Texas Aspect) could be linked to the historic Tonkawa, research by Newcomb and Campbell (1982) indicates that at least one of the groups identified as the Tonkawa were seventeenth century emigresfrom Oklahoma. It seems likely that among the groups that coalesced into the historic Tonkawa were the remnants of older, indigenous Central Texas populations displaced by the push of the Toyah phase peoples.

The first recorded penetration by Europeans into the Williamson County area occurred in A.D. 1716 during the exploration of Domingo Ramon and Louis Juchereau de St. Denis. Ramon and St. Denis encountered Brushy Creek (Arroyo de losBenditos Animas) and the San Gabriel River (Rio de San Franciso Xavier).

The Aguayo expedition passed through the area in A.D. 1721 (Webb 1952). In 1748 and 1749 the Spanish established the San Xavier missions at the request of the Tonkawa and allied groups in the San Gabriel River Valley near the interface of present-day eastern Williamson and western Milam counties (Gilmore 1969).

Although the territory occupied by present-day Williamson County was part of the 1825 Robert LeftwichSterling Clack Robertson impresariogrant during the Mexican period, Anglo-American settlement was slow in coming. A few scattered and vulnerable settlements were established in the San Gabriel and Brushy valleys during the 1830s (Scarbrough 1973:73-76).

The Double File Trail, which crossed the San Gabriel downstream from Georgetown, was perhaps the most important of the trails which crossed the territory. The trail was purportedly laid out by expatriate Delaware Indians in the late 1820 s and became a well-known highway and landmark for Anglo-American settlers (Scarbrough 1973:73-74). Other notable trails crossing the Williamson County area were the Upper Highway and the Military Road (Scarbrough 1973:96)

Increased numbers ofAnglo-American colonists began to settle in the area during the late 1830s and 1840s. The proliferation of fortified Anglo-American settlements, including the Tumlinson Blockhouse Fort (established in 1835 as a ranger outpost) and Kenney's Fort (established c. 1838), suggests the impact of Indian depredations upon settlement in the area (Scarbrough 1973; Webb 1952).

The area which later became Williamson County was part of the Municipality of the District of Viesca during the 1830s. In 1835 the Municipality of Viesca became the Municipality of Milam. Later, the Milam District was one of the twenty-three counties formed during the Republic of Texas period (1836-1845). Williamson County, with Georgetown as the county seat, was formally created from the Milam District in March of 1848 (Webb 1952: 917). 
During the 1850s, small settlements with gins and general stores were established in response to the introduction of cotton to the rich eastern blacklands of Williamson County. After the Civil War, the construction of the International-GreatNorthern Railroad across the county in 1875 led to the development of new towns and caused other settlements to move to the railroad (Webb 1952: 917-918). Ranching is prevalent in the rocky uplands of western Williamson County.
For over a century the primary focus of Williamson County has been agriculture and agribusiness. Although parts of Williamson County have retained the somewhat rural character of the past, the southern portion of the county has undergone rapid development and urbanization due to the close proximity of Austin. 


\begin{tabular}{|c|c|c|c|}
\hline Description & Station & Offset & Elevation \\
\hline Test Unit 1 & $197+84.9$ & $15.3 \mathrm{ft} . \mathrm{RT}$ & Top/East $810.3 \mathrm{ft}$. Top/West $810.2 \mathrm{ft}$. Bottom $808.2 \mathrm{ft}$. \\
\hline Test Unit 2 & $198+79.3$ & $81.3 \mathrm{ft} . \mathrm{RT}$ & Top/East $815.0 \mathrm{ft}$. Top/West $814.5 \mathrm{ft}$. Bottom $812.3 \mathrm{ft}$. \\
\hline Test Unit 3 & $198+66.4$ & $87.6 \mathrm{ft} . \mathrm{RT}$ & Top/East $814.7 \mathrm{ft}$. Top/West $814.7 \mathrm{ft}$. Bottom $812.9 \mathrm{ft}$. \\
\hline Test Unit 4 & $199+63.1$ & $90.5 \mathrm{ft} . \mathrm{RT}$ & Top/East $814.0 \mathrm{ft}$. Top/West $814.0 \mathrm{ft}$. Bottom $812.2 \mathrm{ft}$. \\
\hline Test Unit 5 & $199+37.1$ & $93.3 \mathrm{ft} . \mathrm{RT}$ & Top/East $814.0 \mathrm{ft}$. Top/West $814.0 \mathrm{ft}$. Bottom $812.2 \mathrm{ft}$. \\
\hline Test Unit 6 & $197+01$ & $84.1 \mathrm{ft} . \mathrm{RT}$ & Top/East $810.2 \mathrm{ft}$. Top $/$ West $810.2 \mathrm{ft}$. Bottom $807.7 \mathrm{ft}$. \\
\hline Test Unit 7 & $197+72.8$ & 90.4 ft. RT & Top/East $810.3 \mathrm{ft}$. Top/West $810.4 \mathrm{ft}$. Bottom $809.7 \mathrm{ft}$. \\
\hline Test Unit 8 & $198+96.2$ & $32.4 \mathrm{ft} . \mathrm{RT}$ & Top/East $812.8 \mathrm{ft}$. Top/West $812.8 \mathrm{ft}$. Bottom $811.3 \mathrm{ft}$. \\
\hline Test Unit 9 & $200+22.2$ & 78.1 ft. RT & Top/East $814.7 \mathrm{ft}$. Top $/$ West $814.8 \mathrm{ft}$. Bottom $813.5 \mathrm{ft}$. \\
\hline BHT 'A' north end & $198+49.3$ & $90.3 \mathrm{ft} . \mathrm{RT}$ & Top/NE $814.5 \mathrm{ft}$. Bottom/NE $813.4 \mathrm{ft}$. \\
\hline BHT 'A'central & - & - & Bottom/East $813.2 \mathrm{ft}$. \\
\hline BHT 'A' south end & $198+96.3$ & 91.5 ft. RT & Top/SE $814.3 \mathrm{ft}$. Bottom/SE $812.4 \mathrm{ft}$. \\
\hline BHT B' north end & $199+43.9$ & 93.5 ft. RT & Top/NE 814.1 ft. Bottom/NE 812.4 ft. \\
\hline BHT 'B' central end & & & Bottom/East $812.4 \mathrm{ft}$. \\
\hline BHT 'B'south end & $199+82.9$ & $94.9 \mathrm{ft}$. & Top/SE 814.6 ft. Bottom/SE 812.3 ft \\
\hline
\end{tabular}

TABLE I. Test unit locations in the right-of-way 


\section{Project Methodology}

\section{FieLdWORK}

Testing at $41 \mathrm{WM} 543$ was accomplished with manually dug test units and mechanically excavated trenches (Table 1). The field crew dug a total of nine 1x1$\mathrm{m}$ squares within the right-of-way at the site in order to estimate site dimensions and integrity. The test units and backhoe trenches were placed along the western edge of the right-of-way where evidence of artifacts and burned rock concentrations was revealed by blading.

Test units were dug in arbitrary 10-cm levels; shovels, picks, and trowels were used to remove the fill. All of the soil from the test units was sieved through a 0.25 -in. wire screen. In addition, samples of backdirt mounded by construction equipment were also screened. Any cultural materials recovered during testing were bagged according to proveniencefor further analysis in the lab. Snail shells were collected and bagged separately from lithics.

Level records were kept for all test units, and when the test units were completed, an east wall profile was drawn. Provisions were made for the potential collection of faunal, radiocarbon, or any other samples requiring special handling. Professional surveyors mapped the site, with all units, trenches, construction stakes, and survey markers shown. Color photographs were taken of the unit levels during the project to record the excavation process. The photographs, notes, maps, and forms are all on file at the TxDOT EnvironmentalAffairs Division facilities.

\section{LABORATORY}

All of the cultural materials collected during the testing phase were then processed at the TxDOT lab in Austin. Lithics, which constituted the bulk of the collection, were washed for analysis and labeled with catalog numbers. Each type of artifact was identified in order for the lithic analysis to contribute information about the site. A special sample column was dug in the east wall of BHT 'A' by $10-\mathrm{cm}$ levels; the collected bags from the column were brought back to the lab for processing as a control measure. The burned rock was weighed and discarded, while the artifacts were analyzed. Although plans were made to collect special samples from the column, no charcoal or other datable material was found.

To gain such data, tool characteristicsassociated with morphology and function were examined. For the debitage, platform preparation and stage of decortication served as the basis of classification. Raw material attribution was not included, given the phenomenon of secondary quarries identified nearby. Typing projectile points allowed tentative chronological placement of the sites, but the point type chronologies lack further substantiation by radiocarbon dating.

Analysis of the debitage can assist site interpretation when relative percentages of decortication are known. For example, high percentages of primary flakes compared to tertiary flakes may suggest use of a site as a lithic resource procurement area or workshop. A preponderance of tertiary flakes may imply that prior stages of cortex removal took place elsewhere.

Definitions for artifact classification are presented below. The flaking debris and tool terms refer only to those artifact types observed in the collections from 41WM543. These definitions are offered, not in an attempt to reinvent the wheel, but rather to clarifythe use of terminology in the report. After all, one archeologist's biface blank is another's crude biface.

\section{Artifact Definitions}

\section{Debris from Decortication (Debitage):}

Primary Flakes - Primary flakes are detached from a cobble during the earliest sequences of cortex removal. Primary flakes have approximately $100 \%$ cortex on the dorsal surface. Typically, flake platform preparation is missing. Percentages of primary flakes are generally the highest at sites such as quarries, where the preliminary reduction occurs.

Secondary Flakes - Secondary flakes have dorsal cortication ranging from $1 \%$ to $99 \%$. Striking platforms generally are present but are sometimes absent. The secondary category has the widest variety of forms due to cortex formation.

Tertiary Flakes - No cortex is present on the dorsal face of a tertiary flake. Striking platforms are seen on the majority of complete flakes. Tertiary flakes represent the stage at which all cortex removal from the core has occurred. Tertiary flakes are also known in the literature as interior flakes because of the absence of cortical surface.

Platform Preparation- In order to detach a flake from a core, a flat surface on the core requires preparation. Preparation forms an edge which, when struck, helps to channel the force of the blow, thus disconnecting the flake from the core. The striking platform created as a result of this process is sometimes referred to as faceted or unfaceted, based on the platform's shape. If the dorsal surface of a flake has a single dorsal arris or ridge line, the platform is called faceted (Fac); an unfaceted (Unfac) platform has two dorsal ridges. The faceted platform in transverse cross section forms a triangular shape, while the unfaceted platform appears U- 
shaped in cross section. Occasionally a platform is crushed during flake detachment, leaving the remnants of an unidentifiable platform, misshapen by damage. Primary flakes usually show no cortex removal to form a platform. In some instances, secondary and tertiary flakes may exhibit a platform which looks unprepared (unpre).

Heat T reatment/H eatAlteration - Heat treatment is limited to deliberate action intended to improve the quality of the lithic material, whereas heat alteration is an accidental result of the process for discarding exhausted cores, wornout tools, or lithic debris. Heat-altering chert leaves extensive evidence on the surface of the object in the form of crazing, with fine networks of stress cracks, or potlid fractures that produce small, circular spalls. Deliberate use of heat results in a fine-grained material with a very waxy luster. Color changes may occur in either case. Heat alteration of debris is most frequent at sites with firepit features.

Blades - A flaking platform is required in order to measure accurately the flaking angle. The measurement formula of a blade dictates a length of at least twice that of the width, yielding a long, thin form. Further, a blade measures over $3 \mathrm{~cm}$ in length; a microblade is less than 3 $\mathrm{cm}$ long. Blades are seen in both secondary and tertiary stages of decortication and usually evidence fine marginal retouch when the flake shows use.

Microflakes - A microflake measures less than $1.5 \mathrm{~cm}$ in length, and a microflake always has a platform present. Without the platform, a specimen of flaking debris this size is a chip. Microflakes show secondary or tertiary decortication. Due to the small overall size of microdebitage, the pieces are easily lost through the wire mesh of the screen. Thus the category may not be adequately represented always in the debitage total.

Chips - A flake fragment with a length of less than $1.5 \mathrm{~cm}$, with no striking platform is called a chip. Chips and microflakes represent the smallest lithic debris collected at a site and may indicate tool manufacture and rejuvenation of worn tools requiring fine retouch.

Chunks/shatter - Chunks are rectangular in shape and lack striking platforms. Chunks are associated with broken material left over from core/flakeproduction. Shatter is similar to chunks but generally is identified with breakage and damage caused by heat alteration. Together, these two forms of debris constitute a category of worked materials too marginal for more analysis.

Tested Material - Cobbles offer a valuable source of workable lithic material in an area without primary quarries; knappers selected cobbles and knocked off a few primary flakes to examine the quality of the sample. In some cases, the chert cobble material was too flawed for use as a core, and the cobbles were discarded without further modification. In an area with many secondary lithic sources, tested material is common.
Bifacial Thinning Flakes - Several criteria categorize flakes of this type: The striking platform is lipped; retouch is sometimes seen on the ventral surface of the platform lip. A bifacial thinning flake often shows cortex on the dorsal proximal surface, with distal lateral expansion. Longitudinally, the cross section is markedly concavo-convex. Thinning flakes are associated with edge renewal of bifaces and may be quite small in length when removed for rejuvenation of working edges.

\section{Chipped Stone Tools}

Projectile Points - A bifacially reduced tool with a pointed distal end and a proximal end with notching or edge-grinding for hafting onto a wooden shaft is generally known as a point. This broad definition, however, also includes hafted bifacial tools not attributed to hunting. Points exhibit a wide size range. Flaking may show fine retouch and patterning typical of various point types. Differences in form and manufacture techniques make projectile points temporally diagnostic.

Bifaces - Bifaces are thinned by flake removal on both surfaces and have edge retouch. Found in an array of sizes and overall shapes, these multipurpose tools may show anything from only casual use all the way to reworked, curated pieces. The designation of "biface" is a morphological category which includes many further defined tool types (projectile points, knives, drills) on a very generalized level.

Biface Blanks and Preforms - Unfinished bifacially worked pieces are ubiquitous near secondary quarries. In the stages of biface reduction, a cobble is flaked on both faces, gradually removing all cortex, until a generalized roughout form appears. The earliest stages of this process produce biface blanks, which are marked by edge reduction, often leaving a cortical surface intact centrally on the face. The cortex is detached later in the process as the body of the cobble is reduced, using the previously knapped edge as a striking platform. Preforms continue the procedure to display an almost complete, final form of the tool but lack fine edge retouch. Neither blanks nor preforms present any evidence of use-wear characteristic of finished tools.

Retouched Flakes - These secondary and tertiary flakes possess a line of continuous unifacial flake removals along an edge. Resharpening flake scars and use-wear are also seen. Retouch occurs unifacially on either the dorsal or ventral surface. The edge angles of retouch are not as steep as with scrapers; retouched flakes differ from utilized flakes in that the sharpened edge is deliberately rather than expediently produced. The margins of retouched flakes typically show patterned forms of retouch such as scalar, stepped, flat, or denticulate. 
Utilized Flakes- Unlike retouched flakes, utilized flakes have only sporadic unifacialflake removals caused mainly by use-wear. Edge wear on utilized flakes is described as "nibbling" or "chattering" in token of the minimal effort used to shape the working edge. Some of the edge modification on flakes is inevitably edge damage associated with site disturbance rather than deliberate modification through usage.

Scrapers - Placement of retouch on the flake is on the proximal end or a lateral edge. The tool has a line of continuous retouch, often stepped, with an edge angle of greater than $45 \mathrm{E}$. Angles of the cutting edge are identified as medium (50E to $75 \mathrm{E}$ ), steep (75E to $85 \mathrm{E}$ ), and perpendicular to overhanging ( $>85 \mathrm{E})$. Patterns of retouch may converge at the dorsal ridge(s) or may not merge at a single locus. Continued use necessitates resharpening unifacially, leading to a quite steep, or even overhanging, working edge angle. Scrapers are found in an extensive range of generalized forms, from small endscrapersto large sidescrapers, mostly with a subtriangularshape. Scrapers are usually associated with hide preparation but may have been used for processing vegetal materials.
Gouges - Gouges are thought to have certain chronological affiliations prehistorically in the region. The unifacially (sometimes with bifacial retouch) worked tools are associated with phases in the central Texas late Early Archaic to early Middle Archaic Periods. The two types of gouges are the Clear Fork and Guadalupe types, although not all gouge-like tools are identifiable. The inferred function of gouges is woodworking. The tool has a working edge resembling a chisel bit. The overall shape is generally triangular, with the widest section at the distal end.

Although gouges are large in overall size, the tools usually exhibitcareful manufacturing techniques.

Knife - Thin, bifacial tools which the knapper reduced with fine edge retouch are often classed as knives. Knives will develop use wear along the lateral edges, leaving scalar step-fracturing and edge rounding. Typically a knife will show resharpening flake removals to rejuvenate the worn edge. Knives sometimes were notched for hafting, such as comer-tang tools. Although a triangular overall shape with a sharp distal tip is commonly seen, other forms including acuminate, ovate, or rectangular are known.

Knives were presumably used for cutting. 


\section{Testing Results}

\section{Surface Collection}

Seventeen tools were observed on the surface of the site. The tools were collected as an uncontrolled surface collection, due to the level of surface disturbance. A more intensive survey sampling method was not employed because of the disturbance and human factors. Some of the tools were found by the construction personnel who had reported the subsurface cultural deposition; these tools were given to the departmental archeologist during the onsite inspection.

Among the seventeen tools are four projectile points: one Pedernales point found $3 \mathrm{~m}$ west of Bent \#9 at Drill Site (DS) \#3, one Middle Archaic Untyped point base fragment near PI 197, one Nolan point base fragment south of BHT 'B', and a Bulverde point base fragment probably from the north end of the site near PI 197. Six hafted or stemmed bifaces were also recovered, one near PI 197, one between BHT 'A' and Pl 197, three of unknown location, and one between TU \#2 and TU \#3. In addition, one retouched flake, three utilized flakes, and three biface fragments were collected.

One large piece of graphite and a sandstone mano were identified on the surface just outside the right-of-way.

\section{ExCAVATion}

Two backhoe trenches and nine 1x1-mtest units were excavated at 41WM543. East wall profiles from Test Units 1-9, along with Backhoe Trenches A and B, are located in the appendix of this report.

The backhoe trenches were placed to bisect the exposed burned rock. The ground surface was marked by heavy equipment blading. BHT 'A' was $15 \mathrm{~m}$ in length north to south, while BHT 'B' had a length of $13 \mathrm{~m}$.

\section{Backhoe Trench 'A'}

Three stratigraphic levels (see Appendix A) were observed in the east wall profile. Level 1 was a black silty clay loam, 10Y R2/1. Level 2 was a loose dark gray silty clay loam with a color of 10YR 4/1. Level 3 was a tan silty gravel, 10YR 6/2. Fire-cracked limestone rocks were densely packed throughout the top two levels, and chipped stone was present. A light-colored ashy concentration appeared in the east wall between $5 \mathrm{~m}$ and $6 \mathrm{~m}$, and Test Unit \#3 was dug there. The backdirt from the trench was screened, and artifacts were collected.

A special samples column was taken from the east wall of Backhoe Trench 'A' between $6.50 \mathrm{~m}$ and $7.0 \mathrm{~m}$ to a depth of $50 \mathrm{~cm}$. Lithic artifacts were also identified in the special samples. Burned limestone was collected and weighed from each $10-\mathrm{cm}$ level sample. The results were:

Level $1(0-10 \mathrm{~cm}) 2505.0$ grams of fire-cracked rock Level $2(10-20 \mathrm{~cm}) 2984.5 \mathrm{~g}$

Level $3(20-30 \mathrm{~cm}) 3975.5 \mathrm{~g}$

Level $4(30-40 \mathrm{~cm}) 4568.5 \mathrm{~g}$

Level $5(40-50 \mathrm{~cm}) 6602.0 \mathrm{~g}$

Artifacts collected from the backdirt:

North End. One burin, three projectile points, one projectile point fragment, one knife fragment, one biface preform fragment, two biface fragments, two utilized blades, one utilized tertiary flake fragment, one tested cobble, and one core were retrieved from the backdirt.

Central Portion. One point fragment, one unidentifiable point fragment, one stemmed biface, six biface fragments, one biface preform, one core fragment, one tertiary microblade, and one secondary flake were collected from the backdirt.

General. One secondary flake, six tertiary flakes, two chips, one biface preform fragment, one utilized tertiary flake, and six retouched flakes were recovered from the screened fill after artifact hunters damaged the backhoe trench after working hours.

\section{Backhoe Trench 'B'}

Four stratigraphic levels were seen in BHT 'B' (see Appendix A). After the trench was excavated, it was obvious that the feature observed on the surface represented burned rock and artifacts pushed up by the bulldozer, probably from the area of BHT 'A'. The east wall profile showed that the cultural scatter lay on the original grassy ground surface. This layer was designated Level 1, a loose black silty clay loam with fire-cracked rock, 10YR 2/1 in color. Level 2 was a brownish gray (10YR 3/2) silty clay loam with small gravel. Level 3 was a brownish gray silty clay loam with more roots and less gravel with the same Munsell color number. Level 4 is a tan silty gravel, 10YR 6/2. Despite screening the backdirt, no artifacts were found in the backhoe trench fill.

\section{Test Unit \#1}

Level $1(0-10 \mathrm{~cm})$. TU \#1, a 1x 1-m square, was placed $4.30 \mathrm{~m}$ north of Bent \#9, DS \#1. The fill was black silty clay loam with pea gravel, color lOYR 211. Snail shells were noted, but no cultural materials were recovered.

Level $2(10-20 \mathrm{~cm})$. The soil was a grayish brown (10YR 2/2) silty clay loam, which had a very gravely content. No cultural materials were recovered. 
Level $3(20-30 \mathrm{~cm})$. A brownish gray clayey loam silt (10YR 3/2) constituted the third soil layer. Only one tertiary flake was found in the level at the bottom.

Level $4(30-40 \mathrm{~cm})$. The soil in this level was a continuation from Level 3, then turning into black (10YR $2 / 1$ ) clayey loamy silt was present with small roots. Five pieces of debitage were identified:one tertiary flake, three tertiary microflakes, and one chip.

Level $5(40-50 \mathrm{~cm})$. The 10YR 2/1 color soil was still present, grading into 10YR 4/3. One utilized tertiary flake and one chip were collected.

Level $6(50-60 \mathrm{~cm})$. The soil was a brown clayey loamy silt, 10YR $4 / 3$ in color. One tertiary flake fragment was found in the fill.

Level $7(60-70 \mathrm{~cm})$. The soil was the same as Level 5 . The fill contained no cultural materials

Test Unit \#1 lay northeast of BHT 'A' in an area with an elevation lower than that of the trench. The stratigraphy was mixed and is suggestive of disturbance from stream deposition. The paucity of artifacts in the unit discouraged further investigation in this part of the site.

\section{Test UNIT \#2}

Level $1(0-10 \mathrm{~cm})$. TU \#2 was laid out 2 m east of BHT 'A'. The soil is $10 \mathrm{YR} 2 / 1$, a black silty clay loam with fire-cracked rock and leaf mulch. Two utilized tertiary flakes and 22 pieces of debitage were collected, including two tertiary flakes, nine tertiary flake fragments, two tertiary rnicroflakes, and nine chips.

Level $2(10-20 \mathrm{~cm})$. The soil is the same as Level 1. One utilized tertiary flake and 31 flakes were recovered from the level. The debitage collected is one secondary flake, 13 tertiary flakes, one secondary microflake, three tertiary microflakes, one bifacial thinning flake, and 11 chips.

Level $3(20-30 \mathrm{~cm})$. A dark gray (10YR 4/1) silty clay loam with more roots and fire-cracked rock was seen. One unidentified projectile point fragment, a biface preform fragment, three utilized tertiary flakes, and 48 pieces of debitage. The debitage includes two secondary flakes, 27 tertiary flakes, six tertiary microflakes, one tertiary blade, and 12 chips.

Level $4(30-40 \mathrm{~cm})$. The soil remained unchanged from Level 3. Tree roots dominated. Two utilized flake fragments and 26 pieces of debitage make up the level collection. The debitage includes: two secondary flakes, one secondary blade, nine tertiary flakes, four tertiary microflakes, and 12 chips.

Level $5(40-50 \mathrm{~cm})$. The soil shifted from 10YR $4 / 1$ to a 10YR 5/1 gray silty gravel. The level collection amounted to seven flakes, four of which are tertiary flakes and three of which are tertiary microflakes.

Level $6(50-60 \mathrm{~cm})$. The soil from Level 5 continued on in this level. One biface preform fragment and two utilized tertiary flakes make up the tool collection from the level. The debitage consists of 31 flakes, including three secondary flakes, 14 tertiary flakes, two tertiary microflakes, and 12 chips.

Level $7(60-70 \mathrm{~cm})$. A $10 Y \mathrm{R} 6 / 2$ tan silty gravel was present in the bottom of the level, changing from gray. The flakes and fire-cracked rock were contained within the upper portion of the level. Nine flakes were found, namely, one primary flake, four tertiary flakes, and four chips

Level $8(70-75 \mathrm{~cm})$. The soil from Level 7 remained but with river gravel only. The level was culturally sterile.

\section{Test UNIT \#3}

\section{Outside Ash Concentration}

Level $1(0-10 \mathrm{~cm})$. The pit was placed on the east wall of BHT 'A' to test an ashy concentration. A 10YR 2/1 black silty clay loam with fire-cracked rock was visible into Level 2. One retouched secondary flake, a core fragment, and five utilized flakes were recovered. The 21 flakes found in the level consist of three secondary flakes, 11 tertiary flakes, two tertiary microflakes, two bifacial thinning flakes, and three chips.

Level $2(10-20 \mathrm{~cm})$. The 10YR 2/1 loamy soil continued, turning dark gray (10Y R4/1). One gouge, one projectile point fragment, and seven utilized flakes were collected. The 67 pieces of debitage collected include five secondary flakes, 20 tertiary flakes, 11 tertiary microflakes, two shatter, and 29 chips.

Level $3(20-30 \mathrm{~cm})$. The soil was a dark gray silty clay loam with fire-cracked rock. No tools were present, but two secondary flakes, 27 tertiary flakes, one secondary microflake, one tertiary microflake, and eight chips were found for a total of 39 pieces of debris.

Level $4(30-40 \mathrm{~cm})$. A gray silty gravel with a color of 10 YR 5/1 appeared. The tools include one point fragment, one point fragment, one biface edge fragment, and one retouched tertiary flake. Debitage counts for the level add to 31 flakes, including one primary flake, two secondary flakes, 22 tertiary flakes, two shatter, and four chips.

Level $5(40-50 \mathrm{~cm})$. The soil was the same as Level 4 but changed rapidly to the tan silty gravel (10YR 6/2). One utilized tertiary flake was identified along with 19 pieces of debitage. The debitage is one secondary microflake, seven tertiary flakes, and 11 chips.

Level $6(50-60 \mathrm{~cm})$. The tan silty gravel remained visible. Two utilized flakes and two tertiary flakes were found.

\section{InSIDE AsH C oncentration}

Level $1(2-10 \mathrm{~cm})$. The ashy concentration was pedestaled to investigate its potential as a cultural feature. Level 1 was black silty clay loam (10YR 2/1), the same as 
the fill surrounding the ash. One utilized tertiary flake was found, as was one tertiary flake fragment.

Level $2(10-20 \mathrm{~cm})$. The soil remained unchanged. Fire-cracked rock was scattered throughout. Of the six pieces of debitage collected, one is a primary flake, two are tertiary flakes, and three are tertiary microflakes.

Level $3(20-30 \mathrm{~cm})$. The soil was a loose, dark gray (10YR 4/1) clay loam. A soil sample was taken from the ashy fill in Level 3. Sixteen flakes were collected: two secondary, 10 tertiary, and four tertiary microflakes.

Level $4(30-34 \mathrm{~cm})$. The soil became a tan silty gravel of a $10 Y R \quad 62$ color. One biface preform fragment was recovered with 19 flakes. The debitage includes two secondary flakes, nine tertiary flakes, two tertiary microflakes, three shatter, and three chips. $(34-40 \mathrm{~cm})$ Below the ash concentration, two tertiary flakes were found.

Level 5 (40-50 cm) Below the ash concentration, were the 10Y R $6 / 2$ gravels. One flake, a tertiary flake fragment, was present.

Note that the artifact count was much lower inside the concentration than outside. The number of tools was correspondingly larger outside as well. The soil samples taken from the column were screened through the U.S. Sieve Series, but only microflakes and chips were present. No charcoal or seeds were found.

During the excavation, the ash seemed to resemble limestone powder rather than burned wood ash as from a hearth fire. In fact, no indication of burning was seen in the ash concentration. No evidence of oxidation around the ash was seen; if the concentration was a hearth in situ, one might have expected to see fire-reddened, hardened soil rimming the concentration. The conclusion at this point is to see the ash as decomposing rock and not a cultural feature. No indication of a distinct form was present in the concentration profile. In fact, the ash fill was quite amorphous with no suggestion of anything resembling a basin-shape. Certainly there was no slab-lined pit around the ashy material. It is likely that the concentration represents an intrusive event, where the ashy fill was introduced into the surrounding soil. While it may be true that such limestone ash can only be produced by high temperatures, the occurrence did not happen in place, and the ash does not contribute to site integrity or significance.

\section{Test Unit \#4}

Level $1(0-10 \mathrm{~cm})$. The unit was set on the east wall of BHT ' $\mathrm{B}$ '. This soil layer is the 10YR 2/1 loose black silty clay loam with fire-cracked rock (out of context). Nine tools and 60 flakes were collected. The tools are three biface fragments and six utilized tertiary flakes.

Level $2(10-20 \mathrm{~cm})$. The 10YR 2/1 layer was present, but a grass and hay lens was exposed below the cultural layer. The soil below the grass was a brownish gray (10Y R $3 / 2$ ) silty clay loam with small gravel. Six tools were present in the fill, including two biface fragments, three utilized tertiary flakes, and one retouched tertiary flake fragment. A total of 43 flakes were inventoried: six secondary flakes, nine tertiary flakes, three secondary microflakes, four tertiary microflakes, one shatter, and 20 chips.

Level $3(20-30 \mathrm{~cm})$. The $10 \mathrm{Y} \mathrm{R} 3 / 2$ soil became less gravely and more roots were encountered. One utilized tertiary flake and fifteen flakes were recovered from the level. There are three secondary flakes, three tertiary flakes, one chunk, six chips, and two tertiary microflakes.

Level $4(30-40 \mathrm{~cm})$. In this level, the soil changed to a tannish gray (10YR 5/2) silty gravel at the bottom. Nine pieces of debris was recorded: two secondary flakes, six tertiary flakes, and one chip.

Level $5(40-50 \mathrm{~cm})$. The fill became a 10Y R 62 tan silty gravel, almost soilless. One chip and one tertiary flake were found.

Level $6(50-60 \mathrm{~cm})$. The fill was the same as Level 5. One biface fragment and one utilized secondary flake were the recovered tools. Four flakes, namely, one secondary flake fragment, three tertiary were collected.

AfterTU \#4 was dug, it was clear that the burned rock deposit did not extend this far north on the site. The bulk of the artifacts were in the disturbed upper levels.

\section{Test Unit \#5}

Level $1(0-10 \mathrm{~cm})$. With $\mathrm{TU} \# 5$, the crew once again returned to the proximity of BHT 'A'on the north end of the trench and east of Sta. 198+40. The upper layer was the typical 10Y R 2/1 black silty clay loam fill with small fire-cracked rock and gravel. Three utilized tertiary flakes and a core fragmentappeared in the fill, along with five secondary flakes, 18 tertiary flakes, one chunk, seven shatter, one chunk, one bifacial thinning flake, six tertiary microflakes, and 22 chips.

Level $2(10-20 \mathrm{~cm})$. While the top of the level was 10 YR $2 / 1$, the fill turned to a 10 YR 4/1 dark gray silty clay loam with larger fire-cracked rock. One scraper, one biface fragment, and 10 utilized flakes were collected, for a total of 12 tools. There are 290 flakes in the inventory, including 19 secondary flakes, one secondary microflake, 92 tertiary flakes, 36 tertiary microflakes, one chunk, and 141 chips.

Level $3(20-30 \mathrm{~cm})$. The soil was the same as Level 2. Two Bulverde point fragments, six utilized flakes, and one retouched flake were recovered. The debitage count amounts to 435 pieces: one primary flake, 32 secondary flakes, seven secondary microflakes, 112 tertiary flakes, 61 tertiary microflakes, two tertiary blades, four chunks, and 216 chips. 
Level $4(30-40 \mathrm{~cm})$. The soil remained the same as Level 2. One point base fragment, one biface fragment, and a biface preform fragment were the tools found in the level. Two primary flakes, 18 secondary flakes, three secondary microflakes, 60 tertiary flakes, 22 tertiary microflakes, nine shatter, one bifacial thinning flake, and 102 chips add up to 217 pieces of debitage collected.

Level $5(40-50 \mathrm{~cm})$. The lower level fill was a grayish brown silty gravel with a color of 10YR $2 / 2$. No firecracked rock was present. One utilized tertiary microflake and 41 flakes were retrieved from the fill. The debitage consists of one secondary flake, one secondary microflake, six tertiary flakes, six tertiary microflakes, one shatter, two bifacial thinning flakes, and 24 chips.

Test Unit \#5 revealed a particularly rich deposit of cultural materials. Located close to the right-of-way fence, this unit substantiated the BHT 'A' area on the low knoll as the part of the site within the project with the greatest subsurface potential.

\section{TesT UNIT \#6}

Level $1(0-10 \mathrm{~cm})$. The testing then moved to the north end of the site east of PI 197. Many of the surface finds had come from this location. The soil in TU \#6 proved quite different from the rest of the site, however. The soil was a dark gray 10YR 4/1 compacted loamy clay. One utilized tertiary microflake and one chip were recovered.

Level $2(10-20 \mathrm{~cm})$. A dark gray 10Y R 4/1 loamy clay with roots was seen to some depth. No cultural material was found in the level.

Level $3(20-30 \mathrm{~cm})$. The soil remained the same. No cultural material was found in the level.

Level $4(30-40 \mathrm{~cm})$. The soil changed to $10 \mathrm{YR} 3 / 2$ brownish gray loamy clay with small gravel. No cultural material was found in the level.

Level $5(40-50 \mathrm{~cm})$. A tannish brown (10YR 7/2 loamy) clay with larger gravel replaced the 10YR 3/2 fill. No cultural material was found in the level.

The unit was reduced to a 50x50-cm square in Level 3 when no artifacts were found. As with TU \#1, TU \#6 is located at a lower elevation than the trench area. The subsurface soil deposits do not reflect the amount of cultural materials seen on the disturbed ground surface. The surface scatter may have resulted from grubbing activities by the bulldozer moving soil around.

\section{TesT UNIT \#7}

Level $1(0-10 \mathrm{~cm})$. TU \#7 was placed approximately midway between the locations of TU \#5 and TU \#6. A dark gray (10YR 4/1) loamy clay comprised the fill. Little or no gravel was present. Two utilized flakes and seven pieces of debitage were collected. The debitage consists of four tertiary flakes, two tertiary microflakes, and one chip.

Level $2(10-20 \mathrm{~cm})$. No soil change occurred. No cultural material was found in the level.

TU \#7 was abandoned at $20 \mathrm{~cm}$ due to the dramatic decrease in artifacts. Since continued excavations in TU \#6 were not productive, there was no clear reason to continue in this pit.

\section{Test Unit \#8}

Level $1(0-10 \mathrm{~cm})$. TU \#8 represented an attempt to test the site south and east of BHT 'A'. The fill was a dark gray silty clay loam with a color of 10YR 4/1 and some gravel. One tertiary flake and one chip were recovered.

Level $2(10-20 \mathrm{~cm})$. The fill of the top level became very rocky. One utilized tertiary flake and one biface fragment were present in the fill, along with 18 flakes. The debitage consists of one secondary flake, 12 tertiary flakes, one tertiary microflake, and four chips.

Level $3(20-30 \mathrm{~cm})$. The rocky 10Y R 4/ 1 soil continued. One biface fragment and 41 flakes are recorded in the level. The debitage includes two secondary flakes, eight tertiary flakes, 19 chips, nine tertiary microflakes, and three chips.

Level $4(30-40 \mathrm{~cm})$. The soil was the same as Level 4 at the top, but the soil gave way to a grayish $\tan (10 \mathrm{YR} 5 /$ 2 ) silty gravel. One biface fragment and three chips were present in the upper fill.

Level $5(40-50 \mathrm{~cm})$. The soil was unchanged. No cultural material was found in the level.

The unit contained cultural materials but not in great quantity. It probably represents the northern extent of the site within the project.

\section{Test UnIT \#9}

Level $1(0-10 \mathrm{~cm})$. Test Unit \#9 was placed south of BHT 'B' near the creek. A thin layer of loose brownish gray silty clay humus with a color of $10 Y R 3 / 2$ appeared in Level 1. One utilized tertiary flake, seven tertiary flakes, one tertiary microflakes, and seven chips were found.

Level $2(10-20 \mathrm{~cm})$. The color remained the same, but the fill turned to a silty clay loam with small gravel. Two utilized flakes and 10 pieces of debitage were recovered. There are two tertiary flakes, three tertiary microflakes, and five chips.

Level $3(20-30 \mathrm{~cm})$. No fill changes were noted. One utilized tertiary flake and 20 flakes were collected. Ten tertiary flakes, one secondary flake, three tertiary microflakes and six chips were inventoried.

Level $4(30-40 \mathrm{~cm})$. At the bottom of Level 4 , the fill was a lOYR 712 brownish tan silty gravel. No cultural material was found in the level. 
Testing halted with Test Unit \#9. Test excavations at the site had served to delineate horizontal and vertical dimensions; subsurface cultural deposition was found. Testing indicated that the greatest subsurface artifact density was in the Backhoe Trench 'A' location. Analysis of the cultural materials in the lab was undertaken to evaluate the collected artifacts.

A total of 148 tools (Table 2) and 1714 pieces of debitage (Tables 3 and 4) were collected during testing at 41WM543. The following chapter examines the lithic inventory by functional and morphological characteristics. 


\begin{tabular}{|c|c|c|c|c|c|c|c|c|c|c|c|c|c|c|}
\hline \multirow[t]{2}{*}{ Unit } & \multirow{2}{*}{ Level } & \multicolumn{3}{|c|}{ Primary Flake } & \multicolumn{3}{|c|}{ Secondary Flake } & \multicolumn{3}{|c|}{ Tertiary Flake } & \multicolumn{2}{|c|}{ See Microflake } & \multicolumn{2}{|c|}{ Tertiary Microflakes } \\
\hline & & Unpre & Unid & Frag & Unfac & Fac & Frag & Unfac & $\mathrm{Fac}$ & Frag & Unfac & Fac & Unfac & Fac \\
\hline $\mathrm{TU}-1$ & $\begin{array}{l}1 \\
2 \\
3 \\
4 \\
5 \\
6 \\
7 \\
\end{array}$ & $\begin{array}{l} \\
- \\
- \\
- \\
- \\
- \\
- \\
\end{array}$ & \begin{tabular}{c|}
- \\
- \\
- \\
- \\
- \\
\end{tabular} & \begin{tabular}{|}
- \\
- \\
- \\
- \\
- \\
- \\
- \\
\end{tabular} & \begin{tabular}{l|}
- \\
- \\
- \\
- \\
- \\
- \\
\end{tabular} & $\begin{array}{l}- \\
- \\
- \\
- \\
- \\
- \\
- \\
\end{array}$ & \begin{tabular}{|l|}
- \\
- \\
- \\
- \\
- \\
- \\
\end{tabular} & $\begin{array}{l}- \\
- \\
- \\
- \\
- \\
- \\
- \\
\end{array}$ & $\begin{array}{c}- \\
- \\
- \\
- \\
- \\
- \\
- \\
\end{array}$ & \begin{tabular}{|c|}
- \\
- \\
- \\
1 \\
- \\
1 \\
- \\
\end{tabular} & $\begin{array}{l} \\
- \\
- \\
- \\
- \\
- \\
- \\
\end{array}$ & $\begin{array}{l}- \\
- \\
- \\
- \\
- \\
-\end{array}$ & $\begin{array}{l} \\
- \\
- \\
2 \\
- \\
- \\
-\end{array}$ & $\begin{array}{l}- \\
- \\
- \\
1 \\
- \\
- \\
-\end{array}$ \\
\hline $\mathrm{TU}-2$ & $\begin{array}{l}1 \\
2 \\
3 \\
4 \\
5 \\
6 \\
7 \\
8 \\
\end{array}$ & $\begin{array}{l}- \\
- \\
- \\
- \\
- \\
- \\
1 \\
-\end{array}$ & $\begin{array}{l}- \\
- \\
- \\
- \\
- \\
- \\
- \\
- \\
\end{array}$ & $\begin{array}{l}- \\
- \\
- \\
- \\
- \\
- \\
- \\
-\end{array}$ & $\begin{array}{l}- \\
1 \\
1 \\
- \\
- \\
1 \\
- \\
-\end{array}$ & $\begin{array}{l} \\
- \\
1 \\
1 \\
- \\
- \\
- \\
-\end{array}$ & $\begin{array}{l}- \\
- \\
- \\
1 \\
- \\
2 \\
- \\
-\end{array}$ & $\begin{array}{l}2 \\
2 \\
8 \\
3 \\
1 \\
4 \\
1 \\
- \\
\end{array}$ & $\begin{array}{l}- \\
2 \\
6 \\
1 \\
3 \\
- \\
1 \\
-\end{array}$ & $\begin{array}{c}9 \\
9 \\
13 \\
5 \\
- \\
10 \\
2 \\
- \\
\end{array}$ & $\begin{array}{l}- \\
1 \\
- \\
- \\
- \\
- \\
- \\
-\end{array}$ & $\begin{array}{l}- \\
- \\
- \\
- \\
- \\
- \\
-\end{array}$ & $\begin{array}{l}2 \\
3 \\
5 \\
3 \\
2 \\
2 \\
- \\
- \\
\end{array}$ & $\begin{array}{l}- \\
- \\
1 \\
1 \\
1 \\
- \\
- \\
-\end{array}$ \\
\hline $\begin{array}{c}\mathrm{TU}-3 \\
\text { outside ash concentration }\end{array}$ & $\begin{array}{l}1 \\
2 \\
\mathbf{3} \\
4 \\
5 \\
\mathbf{6} \\
\end{array}$ & $\begin{array}{l}- \\
- \\
1 \\
- \\
-\end{array}$ & $\begin{array}{l}- \\
- \\
- \\
- \\
- \\
\end{array}$ & $\begin{array}{l}- \\
- \\
- \\
- \\
- \\
\end{array}$ & $\begin{array}{l}2 \\
3 \\
- \\
2 \\
- \\
1 \\
\end{array}$ & $\begin{array}{l} \\
1 \\
\text { I } \\
- \\
- \\
.\end{array}$ & $\begin{array}{l}1 \\
1 \\
1 \\
- \\
- \\
1 \\
\end{array}$ & $\begin{array}{c}4 \\
4 \\
15 \\
5 \\
2 \\
\mathrm{I} \\
\end{array}$ & \begin{tabular}{|l}
1 \\
2 \\
1 \\
4 \\
1 \\
1 \\
- \\
\end{tabular} & $\begin{array}{c}6 \\
14 \\
11 \\
3 \\
4 \\
1 \\
\end{array}$ & $\begin{array}{c} \\
11 \\
I \\
- \\
\mathbf{I} \\
-\end{array}$ & - & $\begin{array}{l}- \\
- \\
1\end{array}$ & - \\
\hline $\begin{array}{c}\text { T U - } 3 \\
\text { inside ah concentration }\end{array}$ & $\begin{array}{l}l \\
2 \\
3 \\
4 \\
5 \\
6 \\
\end{array}$ & $\begin{array}{l} \\
\text { I } \\
- \\
- \\
- \\
-\end{array}$ & $\begin{array}{l}- \\
- \\
- \\
- \\
- \\
- \\
\end{array}$ & $\begin{array}{l}- \\
- \\
- \\
- \\
- \\
-\end{array}$ & $\begin{array}{l} \\
- \\
- \\
- \\
- \\
-\end{array}$ & $\begin{array}{c}- \\
\text { I } \\
- \\
\text { I } \\
- \\
- \\
\end{array}$ & $\begin{array}{l}- \\
1 \\
2 \\
1 \\
- \\
-\end{array}$ & $\begin{array}{l}- \\
\text { I } \\
4 \\
3 \\
- \\
- \\
\end{array}$ & $\begin{array}{l}- \\
\mathrm{I} \\
1 \\
- \\
- \\
- \\
\end{array}$ & $\begin{array}{l}5 \\
8 \\
1 \\
- \\
\end{array}$ & $\begin{array}{l}- \\
- \\
-\end{array}$ & & $\begin{array}{l}3 \\
4 \\
2\end{array}$ & \\
\hline TU -4 & $\begin{array}{l}1 \\
2 \\
3 \\
4 \\
5 \\
6 \\
\end{array}$ & $\begin{array}{l}1 \\
- \\
- \\
- \\
-\end{array}$ & $\begin{array}{l}- \\
- \\
- \\
- \\
- \\
- \\
\end{array}$ & $\begin{array}{l}- \\
- \\
- \\
- \\
- \\
-\end{array}$ & $\begin{array}{l}5 \\
1 \\
1 \\
2 \\
- \\
- \\
\end{array}$ & $\begin{array}{l}3 \\
2 \\
2 \\
- \\
- \\
- \\
\end{array}$ & $\begin{array}{l}3 \\
3 \\
- \\
- \\
1 \\
1 \\
\end{array}$ & $\begin{array}{l}6 \\
- \\
2 \\
- \\
- \\
1 \\
\end{array}$ & $\begin{array}{l}2 \\
3 \\
1 \\
2 \\
- \\
- \\
\end{array}$ & $\begin{array}{|cc|}1 & 4 \\
& 6 \\
& - \\
& 4 \\
& - \\
2\end{array}$ & $\begin{array}{l}2 \\
2 \\
- \\
-\end{array}$ & $\begin{array}{l}\text { I } \\
1\end{array}$ & $\begin{array}{l}3 \\
3 \\
2\end{array}$ & $\begin{array}{l}2 \\
\mathrm{I}\end{array}$ \\
\hline TU -5 & $\begin{array}{l}\text { I } \\
2 \\
3 \\
4 \\
5 \\
\end{array}$ & $\begin{array}{l}- \\
- \\
1 \\
2 \\
- \\
\end{array}$ & $\begin{array}{l}- \\
- \\
= \\
- \\
- \\
\end{array}$ & $\begin{array}{l}- \\
- \\
- \\
-\end{array}$ & $\begin{array}{c} \\
8 \\
12 \\
9 \\
1 \\
\end{array}$ & $\begin{array}{l}- \\
1 \\
3 \\
2 \\
-\end{array}$ & \begin{tabular}{c|}
4 \\
10 \\
17 \\
7 \\
- \\
\end{tabular} & $\begin{array}{cc} & \\
27 & \\
20 & \\
1 & 6 \\
1 & \\
\end{array}$ & \begin{tabular}{|c|}
3 \\
5 \\
9 \\
9 \\
1 \\
\end{tabular} & 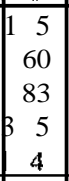 & $\begin{array}{l}- \\
1 \\
1 \\
2 \\
1\end{array}$ & $\begin{array}{l}- \\
6 \\
\text { I }\end{array}$ & $\begin{array}{c}4 \\
27 \\
48 \\
17 \\
6 \\
\end{array}$ & $\begin{array}{c}2 \\
Y \\
13 \\
5\end{array}$ \\
\hline TU -6 & $\begin{array}{l}1 \\
2 \\
3 \\
4 \\
5 \\
\end{array}$ & $\begin{array}{l}- \\
- \\
- \\
-\end{array}$ & $\begin{array}{l}- \\
- \\
- \\
- \\
-\end{array}$ & $\begin{array}{l}- \\
- \\
- \\
- \\
-\end{array}$ & $\begin{array}{l}- \\
- \\
- \\
- \\
-\end{array}$ & $\begin{array}{l}- \\
- \\
- \\
- \\
-\end{array}$ & $\begin{array}{l}- \\
- \\
- \\
- \\
-\end{array}$ & $\begin{array}{l}- \\
- \\
- \\
- \\
-\end{array}$ & \begin{tabular}{l|}
- \\
- \\
- \\
- \\
- \\
\end{tabular} & $\begin{array}{l}- \\
- \\
- \\
-\end{array}$ & $\begin{array}{l}- \\
- \\
- \\
- \\
-\end{array}$ & & 1 & \\
\hline $\mathrm{TU}-7$ & $\begin{array}{l}\mathrm{I} \\
\mathrm{I}\end{array}$ & - & - & - & 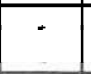 & - & - & $\begin{array}{l}2 \\
-\end{array}$ & $\begin{array}{l}1 \\
-\end{array}$ & 1 & $\overline{-}$ & & 2 & \\
\hline TU -8 & $\begin{array}{l}1 \\
2 \\
3 \\
4 \\
\end{array}$ & $\begin{array}{l}- \\
- \\
-\end{array}$ & $\begin{array}{l}- \\
- \\
- \\
\end{array}$ & $\begin{array}{l}- \\
- \\
-\end{array}$ & $\begin{array}{l}- \\
- \\
1 \\
\end{array}$ & $\begin{array}{l}- \\
1 \\
-\end{array}$ & $\begin{array}{l}- \\
1 \\
-\end{array}$ & $\begin{array}{l}- \\
5 \\
3 \\
-\end{array}$ & $\begin{array}{l} \\
2 \\
-\end{array}$ & $\begin{array}{l}- \\
5 \\
5 \\
-\end{array}$ & $\begin{array}{l}- \\
- \\
- \\
\end{array}$ & $\begin{array}{l}- \\
- \\
- \\
\end{array}$ & $\begin{array}{l} \\
1 \\
9 \\
- \\
\end{array}$ & $\begin{array}{l}- \\
- \\
- \\
\end{array}$ \\
\hline TU -9 & \begin{tabular}{|l}
1 \\
2 \\
3 \\
4 \\
\end{tabular} & $\begin{array}{l}- \\
- \\
- \\
\end{array}$ & $\begin{array}{l}- \\
- \\
- \\
-\end{array}$ & $\begin{array}{l}- \\
- \\
-\end{array}$ & $\begin{array}{l}- \\
1 \\
-\end{array}$ & $\begin{array}{l}- \\
- \\
-\end{array}$ & - & $\begin{array}{l}- \\
- \\
-\end{array}$ & $\begin{array}{l}3 \\
- \\
- \\
\end{array}$ & $\begin{array}{l}4 \\
1 \\
6 \\
-\end{array}$ & $\begin{array}{l}- \\
- \\
- \\
\end{array}$ & $\begin{array}{l}- \\
- \\
- \\
\end{array}$ & $\begin{array}{l}1 \\
3 \\
2 \\
-\end{array}$ & $\begin{array}{l}- \\
1 \\
\end{array}$ \\
\hline \multicolumn{2}{|c|}{ BHT 'A' backdirt collection } & - & - & - & 1 & - & 1 & 3 & 2 & - & - & - & - & - \\
\hline \multicolumn{2}{|l|}{ BHT 'A' north end } & - & - & - & - & - & - & - & - & - & - & - & - & - \\
\hline \multicolumn{2}{|l|}{ BHT 'A' central portion } & - & - & - & 1 & - & - & - & - & - & - & - & - & - \\
\hline \multicolumn{2}{|c|}{ Surface near PI 197} & - & - & - & - & - & - & - & - & - & - & - & - & - \\
\hline \multicolumn{2}{|c|}{ Surface between BHT 'A' and PI } & - & - & - & - & - & - & - & - & - & - & - & - & - \\
\hline \multicolumn{2}{|c|}{ Surface south of BHT B' } & - & - & - & - & - & - & - & - & - & - & - & - & - \\
\hline BHT 'A'surface & & - & - & - & - & - & - & - & - & - & - & - & - & - \\
\hline
\end{tabular}

TABLE 2. Debitage collection at 41WM543: Flake reduction. 


\section{Lithic Analysis}

\section{Debitage}

Of the 1714 flakes and other items of chipping debris, the category of chips was the most common at 728 pieces or $42.4 \%$ of the total collection. Heat-fracturing is a possible contributing factor to the dominance of this class of flakes, increasing the overall number by breaking the flakes into smaller spalls of chert. Indeed, chips do show the most heat damage of all the flake categories at the site. It is surprising, though, that chips would edge out tertiary flakes in prominence, however. Tertiary flakes, usually the clear majority in debitage inventories, only amount to $33.3 \%$ (572 pieces) of the total. Generally, it is assumed that larger flakes would have an advantage in screen collection because the larger the flake, the easier it is to see. Although it is reassuring that our methods were intensive enough to collect adequately in the smaller size range, the predominance of chips is unusual.

The flake counts drop dramatically in number after the major categories of chips and tertiary flakes. Tertiary microflakes amounted to $11.3 \%$ or 195 pieces, while secondary flakes were next with 134 items or $7.8 \%$. Secondary microflakes and chunks/shatter both occupy the same percentage, $1.8 \%$, with 32 pieces each. All the other categories such as primary flakes, secondary blades, tertiary blades, bifacial thinning flakes, and core fragments register less than seven pieces each and have percentages less than $1.0 \%$.

As far as flake totals by excavation unit, Test Unit \#5 was the obvious source of most of the debitage. Over $60 \%$ of all flakes recorded at 41WM543 (1044 pieces) were found in the unit. If the totals for Test Unit \#3 are combined for levels both within the ash concentration and outside the ash, $13.5 \%$ or 234 pieces of debitage came from the unit. Test Unit \#2 is next with $10.2 \%$ (175) of the total, then Test Unit \#4 with 133 pieces (7.7\%), Test Unit \#8 with 60 pieces or $3.5 \%$, and Test Unit \#9 with $2.3 \%$ (40 pieces). Test Units \#1, \#6 and \#7 all yielded less than $1.0 \%$ each of the total debitage with seven or fewer flakes each.

The flake collection may have implications for not only site dimensions but also site function. Clearly, the debitage is concentrated in the area of the low knoll where BHT 'A' and TU \#5 were placed near the west right-ofway fenceline. Debitage counts drop off precipitously in the test units further away from the burned rock concentration. Concerning site function, the small size range of the debitage suggests extensive knapping activities at the site.

\section{Chipped Stone Tools}

At 41WM543, there were 148 tools collected on the surface and in excavation units. Tools represented at the site include projectile points, hafted bifaces, biface fragments, a scraper, a burin, a knife, retouched flakes, and utilized flakes/blades. Each category of tool is described below to assess the implications on site significance for such questions as chronology or functionality. The dearth of other artifact types leaves the lithic artifacts as the only means of analyzing the site.

\section{ProjectIle Points (Figures 3 and 4)}

Seventeen projectile points were recovered on the surface and from excavation units.

Possible Early Split Stem Series (1 specimen)

Chronological Affiliation: Early Archaic, circa 8500-

6000 B.C (Johnson 1997:134; Prikryl 1990: fig. 24))

Provenience: Backdirt collection at north end of Backhoe

Trench 'A' (Figure 3a)

Dimensions: L: $31 \mathrm{~mm}(\mathrm{Br})$; W: $29 \mathrm{~mm}(\mathrm{Br})$; NW: 15

mm; Th: $6 \mathrm{~mm}$

Description: Most of the chert projectile point blade above the stem is broken by irregular fractures. An attempt to rework the broken blade into a hafted tool was made. The eared stem is long with slightly concave laterals and a concave base. The piece is thickest below the shoulders and biconvex. The edge retouch is rough. The flaking is fine and nonpatterned. The base fragment has evidence of beveling. Johnson (1997: 134) describes this type as a "generic group," but one characterized by the pressure flake removal.

\section{ANDICE TYPE (1 SPECIMEN)}

Chronological Affiliation: Early Archaic, circa 4050-

3050 B.C. (Turner and Hester 1985:71)

Provenience: Test Unit \#5, Level $3(20-30 \mathrm{~cm})$ (Figure

3b)

Dimensions: L: $27.5 \mathrm{~mm}(\mathrm{Br})$; W: 28 mm; NW: $28 \mathrm{~mm}$

(Br); Th: 7 mm (Figure 3b);

Description: Figure 3b.An irregular medial break fractured the chert point fragment. Biconvex in transverse section, the base fragment is broken just above the shoulders. The lateral edges of the blade look unfinished; in fact, the blade is rougher than the stem. The shoulders are almost nonexistent and slope gently into the stem. On the stem, the lateral edges are parallel; the base is straight. The stem is narrow and somewhat attenuated. 


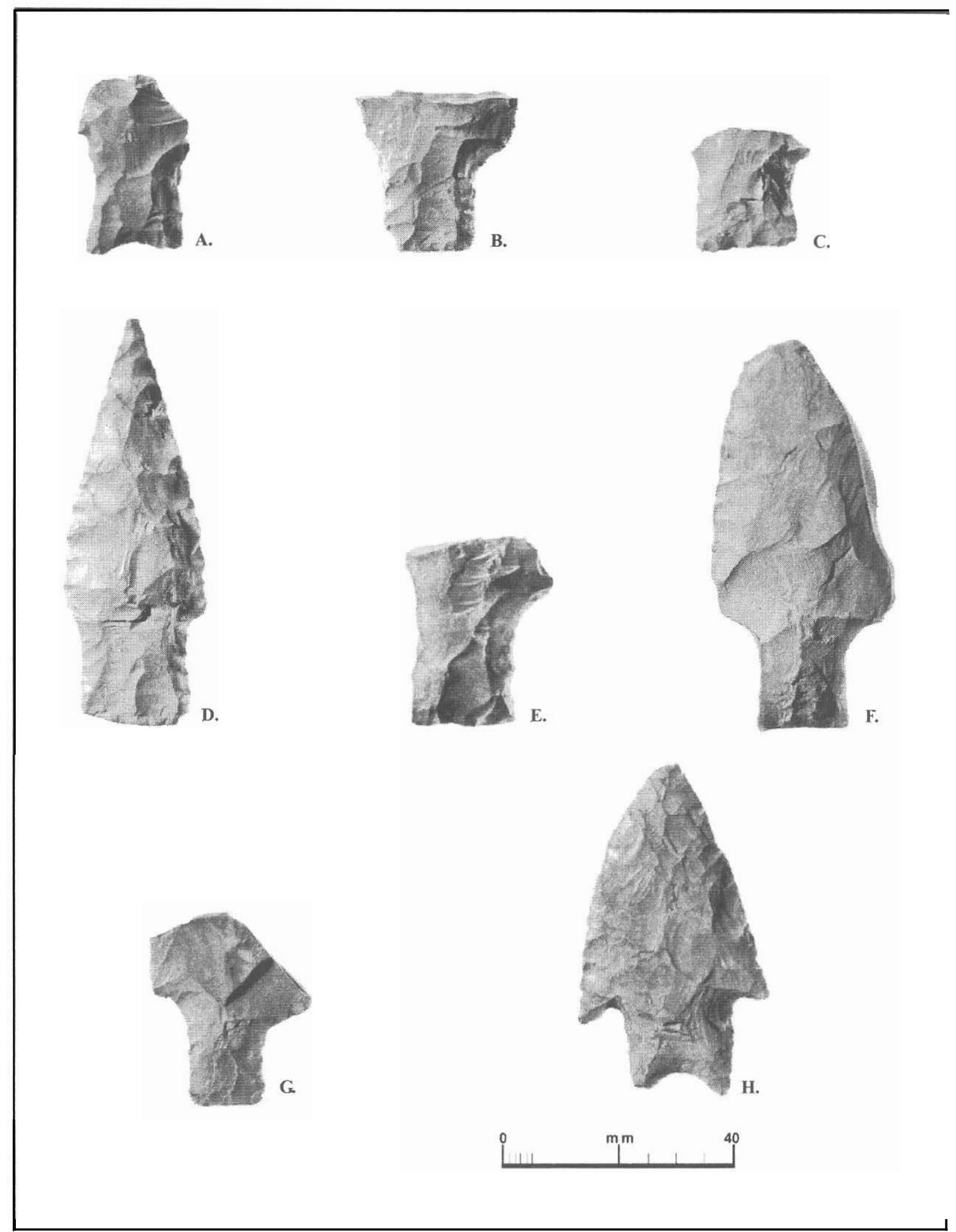

FIGURE 3. Projectile point types collected from 41WM543. A. possible early split-stem series: Backdirt at north end of BHT 'A': B. oossible Andice: Test Unit 5. level $3(20-30 \mathrm{~cm})$ : C. - D. Rulverde: backdiet at north end of BHT 'A' : E. - G Nolan: E. surface south of BHT 'B', F. TU 3. level $4(30+40 \mathrm{~cm})$. G. backdirt at north end of BHT 'A': H. Pedemales: surface west of Bent \#9. DS $\# 3$. 


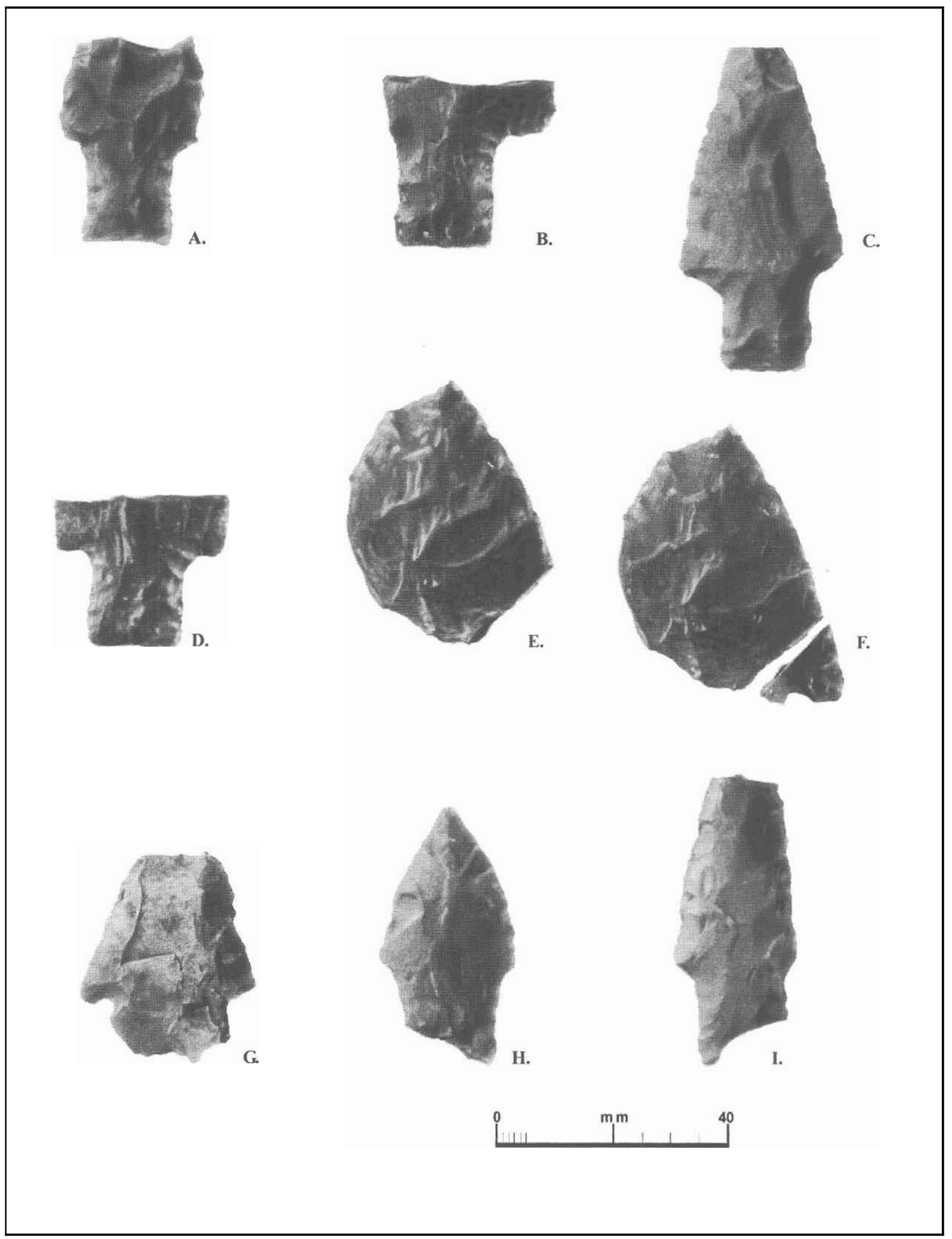

FIGURE 4. Projectile point types collected from 4IWM543. A - D. Middle Archaic Untyped: A. surface collection; B. Test Unit 3. level 4 (30-40 cm): C. Test Unit 5. level $3(20-20 \mathrm{~cm})$; D. surface near PI 197: E. Late Pedernales/ Marshall/Montell: Test Unit 2, level $3(20-30 \mathrm{~cm})$ : F, possible Post-Montell: backdirt, central portion of BHT 'A': G unidentified: backdirt. central portion of BHT 'A'. 


\begin{tabular}{|c|c|c|c|c|c|c|c|c|c|c|c|}
\hline Unit & Level & Projectile & Biface & Biface & Utilized & Retouched & Scraper & Burin & Gouge & Knife & Totals \\
\hline \multirow{7}{*}{ TU-1 } & 1 & - & - & - & - & - & - & - & - & - & - \\
\hline & 2 & - & - & - & - & - & - & - & - & - & - \\
\hline & 3 & - & - & - & - & - & - & - & - & - & - \\
\hline & 4 & - & - & - & - & - & - & - & - & - & - \\
\hline & 5 & - & - & 1 & 1 & - & - & - & - & - & 2 \\
\hline & 6 & - & - & - & - & - & - & - & - & - & - \\
\hline & 7 & - & - & - & - & - & - & - & - & - & $=2$ \\
\hline \multirow[t]{8}{*}{ TU-2 } & 1 & - & - & - & 2 & - & - & - & - & - & 2 \\
\hline & 2 & - & - & - & 1 & - & - & - & . & - & 1 \\
\hline & 3 & I & - & 1 & 3 & - & - & - & - & - & 5 \\
\hline & 4 & - & - & - & 2 & - & - & - & - & - & 2 \\
\hline & 5 & - & - & 1 & 2 & - & - & - & - & - & 3 \\
\hline & 6 & - & - & - & - & - & - & - & - & - & - \\
\hline & 7 & - & - & - & - & - & - & . & . & - & - \\
\hline & 8 & - & - & - & - & - & - & - & - & - & $=13$ \\
\hline \multirow{6}{*}{$\begin{array}{l}\text { TU-3 outside ash } \\
\text { concentration }\end{array}$} & 1 & - & - & - & 5 & 1 & - & - & - & - & 6 \\
\hline & 2 & 1 & - & - & 7 & - & - & - & 1 & - & 9 \\
\hline & 3 & - & - & - & - & - & - & - & - & - & - \\
\hline & 4 & 2 & 1 & - & . & 1 & - & - & - & . & 4 \\
\hline & 5 & - & - & - & 1 & - & - & - & - & - & 1 \\
\hline & 6 & - & - & - & 2 & - & - & - & - & - & $2=22$ \\
\hline \multirow{6}{*}{$\begin{array}{l}\text { TU-3 within ash } \\
\text { concentration }\end{array}$} & 1 & - & - & - & 1 & - & - & - & - & - & 1 \\
\hline & 2 & - & - & - & - & - & - & - & - & - & - \\
\hline & 3 & - & 1 & - & - & - & - & - & - & - & 1 \\
\hline & 4 & - & - & 1 & 3 & - & - & - & - & - & 4 \\
\hline & 5 & - & - & - & - & - & - & - & - & - & - \\
\hline & 6 & - & - & - & - & - & - & - & - & - & $=6$ \\
\hline \multirow[t]{6}{*}{ TU-4 } & 1 & - & 3 & - & 6 & - & - & - & - & - & 9 \\
\hline & 2 & - & 3 & - & 3 & 1 & - & - & - & - & 7 \\
\hline & 3 & - & - & - & 1 & - & - & - & - & - & 1 \\
\hline & 4 & - & - & - & - & - & - & - & - & - & - \\
\hline & 5 & - & - & - & - & - & - & - & - & - & - \\
\hline & 6 & - & 1 & - & 1 & - & - & - & - & - & $2=19$ \\
\hline \multirow[t]{5}{*}{ TU-5 } & 1 & - & - & - & 3 & - & - & - & - & - & 3 \\
\hline & 2 & - & 1 & - & 10 & - & 1 & - & - & - & 14 \\
\hline & 3 & 2 & - & . & 6 & 1 & - & - & - & - & 9 \\
\hline & 4 & 1 & 1 & 1 & 2 & - & - & - & - & - & 5 \\
\hline & 5 & - & - & - & 1 & - & - & - & - & - & $1=32$ \\
\hline \multirow[t]{5}{*}{ TU-6 } & 1 & - & - & - & - & - & - & - & - & - & - \\
\hline & 2 & - & - & - & - & - & - & - & - & - & - \\
\hline & 3 & - & - & - & - & - & - & - & - & - & - \\
\hline & 4 & - & - & - & - & - & - & - & - & - & - \\
\hline & 5 & - & - & - & - & - & - & - & - & - & $=0$ \\
\hline \multirow[t]{2}{*}{ TU-7 } & 1 & - & - & - & 2 & - & - & - & - & - & 2 \\
\hline & 2 & - & - & - & - & - & - & - & - & - & $=2$ \\
\hline \multirow[t]{5}{*}{ TU-8 } & 1 & - & - & - & - & - & - & - & - & - & - \\
\hline & 2 & - & 1 & - & 1 & - & - & - & - & - & 4 \\
\hline & 3 & - & . & - & . & - & - & - & - & - & - \\
\hline & 4 & - & 1 & - & - & - & - & - & - & - & 1 \\
\hline & 5 & - & - & - & - & - & - & - & - & - & $=3$ \\
\hline \multirow[t]{4}{*}{ TU-9 } & 1 & - & - & - & 1 & - & - & - & - & - & 1 \\
\hline & 2 & - & - & - & 2 & - & - & - & - & - & 2 \\
\hline & 3 & - & - & & 1 & - & - & - & - & - & 1 \\
\hline & 4 & - & - & - & - & - & - & - & - & - & $=4$ \\
\hline \multicolumn{2}{|c|}{ Surface between TU-2 \& TU-3 } & - & - & 1 & - & - & - & - & - & - & $1=1$ \\
\hline Surface east of Tl & & - & - & 1 & - & - & - & - & - & - & $1=1$ \\
\hline Surface 3 meters & tof Bent 9 & 1 & - & - & - & - & - & - & - & - & $1=1$ \\
\hline Surface near PI19 & & 1 & 1 & - & - & - & - & - & - & - & $2=2$ \\
\hline Surface between $\mathrm{F}$ & T'A'\& & - & 1 & - & - & - & - & - & - & - & $1=1$ \\
\hline Surface south of $\mathrm{E}$ & & 1 & - & - & - & - & - & - & - & - & $1=1$ \\
\hline Surface & & 1 & 1 & 4 & 3 & 1 & - & - & - & - & $10=10$ \\
\hline BHT'A'backdirt 1 & $\mathrm{~h}$ end & 4 & 2 & 1 & 3 & - & - & 1 & - & 1 & $12=12$ \\
\hline BHT'A' backdirt o & & 2 & 7 & 1 & - & - & - & - & - & - & $10=10$ \\
\hline \begin{tabular}{|l|} 
BHT'A' \\
\end{tabular} & & - & - & 1 & 1 & 6 & - & - & - & - & $8=8$ \\
\hline
\end{tabular}

TABLE 3. Tools collected at 41 WM543 


\section{BULVERDE TYPE (2 SPECIMENS)}

Chronological Affiliation: Early Archaic, circa 30002500 B.C. (Turner and Hester 1985:73); Early Middle Archaic, Central Texas Clear Fork Phase, Local Period 6, 3500-2000 B.C. (Black and McGraw 1985:116)

Provenience: Backdirt collection at north end of Backhoe Trench 'A' (Figure 3c-d);

Dimensions: L: $70 \mathrm{~mm}$; W: $34.5 \mathrm{~mm}$; NW: $19 \mathrm{~mm}$; Th: 8 mm (Figure 3d); L: 21 mm (Br); W: 21 mm (Br); NW: $16.5 \mathrm{~mm}$; Th: $6 \mathrm{~mm}$ (Figure 3c);

Description: Figure 3d. Although the chert point is nearly complete, the distal tip is snap-fractured. The blade is a long, narrowly triangular shape with shallow shoulders. The stem has nearly parallel lateral edges with a straight base. The stem is almost as wide as the blade. The point is biconvex in transverse section. Deep step-fractures are noticeable on one face at the haft element, probably in an attempt to thin the tool. Some edge rounding is present on the stem lateral edges. The flaking is fine and nonpatterned.

Figure 3c. A hinge-fiacture removed the blade at the shoulders, leaving a wide, squared stem with nearly parallel lateral edges and a thinned, straight base. There is some edge rounding at the haft element. The chert point is biconvex in transverse section. Fine nonpatternedflaking covers the stem.

Bulverde projectile points are generally recognized by narrow stem elements and strong shoulders. Some of these specimens show an elongated stem characteristic of a Bulverde variant form. Compare the points to the examples of unidentified Clear Fork points from the Cervenka site, 41WM267 (Hays et al 1982:14-27).

Nolan TYPE (3 SPECIMENS)

Chronological Affiliation: Early Archaic, circa 40002500 B.C. (Turner and Hester 1985:132); Early Middle Archaic, Central Texas Clear Fork Phase, Local Period 6, 3000-2000 B.C. (Black and McGraw 1985:117)

Provenience: Surface south of Backhoe Trench 'B' (Figure 3e); Test Unit \#3, Level $4(30-40 \mathrm{~cm})$ outside ashy concentration (Figure 3f); Backdirt collection at north end of Backhoe Trench 'A' (Figure 3g);

Dimensions: L: $34 \mathrm{~mm}(\mathrm{Br})$; W: $36 \mathrm{~mm}$; NW: $18 \mathrm{~mm}$; Th: 8mm (Figure 3e); L: $69.5 \mathrm{~mm}$; W: $33 \mathrm{~mm}(\mathrm{Br})$; NW: 16 mm; Th: $8 \mathrm{~mm}$ (Figure 3f); L: 36 mm; W: $30 \mathrm{~mm}(\mathrm{Br})$; NW: $14 \mathrm{~mm}$; Th: $6.5 \mathrm{~mm}$ (Figure $3 \mathrm{~g}$ )

Description: Figure 3e. Alternate beveling is apparent on the chert point stem lateral edges. The thinned base is fairly straight. An irregular medial fracture removed the distal end, and a burin blow took off one lateral edge of the blade, moving proximally from the medial break. The point is biconvex in transverse section.

Figure 3f: Thin, with a straight base, the chert point has one lateral missed due to a snap-fracture. The distal tip is broken off by a deep hinge; apparently there was some later attempt to rework the tip. The straight stem is alternately beveled on the lateral edges. The shallowly contracting shoulders are not barbed. Biconvex in transverse section, the tool is made from rather coarse lithic material, but the flaking is finely executed.

Figure $3 g$. The chert point blade is broken medially by an impact fracture, removing all of the blade but one shoulder. The remaining shoulder is shallow, with no barb. The stem is narrowly parallel with a straight base. The edge retouch on the stem is step-fractured. The fragment is biconvex in transverse section.

These large stemmed projectile points fit into the Nolan type due to the characteristic alternate beveling on the stem laterals and convex blade lateral edges.

\section{PEDERNALES TYPE (1 SPECIMEN)}

Chronological Affiliation: Middle Archaic, circa 20001200 B.C. (Turner and Hester 1985: 139); Middle Archaic, Central Texas Round Rock Phase, Local Period 7,2000600 B.C. (Black and McGraw 1985:113)

Provenience: Surface collection 3 m west of Bent \#9, DS \#3 (Figure 3h)

Dimensions: L: $61 \mathrm{~mm}$; W: $35 \mathrm{~mm}$; NW: 20 mm; Th: 7.5 $\mathrm{mm}$

Description: Figure $3 \mathrm{~h}$. The chert point has a broadly triangular blade element with a blunt distal tip; it is unclear whether the tip is reworked or merely broken. The slightly convex blade lateral edges have prominent barbs, one of which is broken. Edge retouch is present on the blade. The stem has parallel lateral edges and a thinned, deeply concave base. The piece is biconvex in transverse section. Fine nonpatterned flaking characterizes the manufacture of the tool. overall, the particularly thin specimen shows skilled workmanship.

Pedernales points have a wide range of variation united by the common trait of a thinned, deeply indented stem. This specimen has a stem typical of that form.

\section{Middle A r c $\mathrm{h}$ a i c UNTYPED (4 SPECIMENS)}

Chronological Affiliation: Middle Archaic, circa 2500-

1000 B.C.(Turnerand Hester 1985:57); ca. 4050-3050

B.C. (Johnson 1997: 181)

Provenience: Surface collection (Figure 4a); Test Unit \#3, Level 4 (30-40 cm) (Figure 4b); Test Unit \#5, Level 3 (20$30 \mathrm{~cm}$ ) (Figure 4c)

Dimensions: L: $38 \mathrm{~mm}(\mathrm{Br})$; W: $25.5 \mathrm{~mm}$; NW: $6 \mathrm{~mm}$; Th: $6.5 \mathrm{~mm}$ (Figure 4a); L: $29.5 \mathrm{~mm}$ (Br); W: $30 \mathrm{~mm}(\mathrm{Br})$; NW: 18 mm; Th: 8 rm (Figure 4b); L: $58.5 \mathrm{~mm}(\mathrm{Br})$; W: $30 \mathrm{~mm}$; NW: $16 \mathrm{~mm}$; Th: $7 \mathrm{~mm}$ (Figure 4c); L: $28 \mathrm{~mm}$; W: $32 \mathrm{~mm}$; NW: $17 \mathrm{~mm}$; Th: $5.5 \mathrm{~mm}$ (Figure 4d)

Description: Figure 4a. A medial hinge-fracture removed the distal end. The chert point fragment is biconvex in transverse section. The somewhat convex lateral edges of the blade show preparation for retouching; the blade 
shoulders are shallow. Fine nonpatterned flaking is present on the stem but not on the blade. The elongated blade has a slightly concave base and nearly parallel lateral edges. Edge rounding is present at the haft element.

Figure 4b. Biconvex in transverse section, only the base of the tool remains. The chert point fragment is broken by an irregular medial break which continues down one side, leaving no evidence of the blade on one edge. The one shoulder present is squared and extends well away from the stem. The elongated stem has a straight base and parallel lateral edges. The flaking is fine and nonpatterned. Figure 4c. The distal tip of the chert projectile point was broken off by an impact fracture. The triangular blade element has irregular, step-fractured lateral edges. The blade is also step-fractured on the midline. A straight base and parallel lateral edges are present on the stem. The tool is biconvex in transversesection.

Figure 4d. Heat-altered, the chert point base fragment is fractured with potlids. The medial snap-fracture detached the distal end above parallel blade laterals. The stem also has parallel lateral edges and a somewhat concave base. Edge rounding is apparent on the stem at the haft element. The point is quite thinly biconvex in transverse section.

\section{LATE P eder nales / M ar sha II/ M on tel I Type (1 SPECIMEN)} Chronological Affiliation: Late Archaic I subperiod, ca. 2000-1000 B.C. (Johnson 1997:181)

Provenience: : Test Unit \#2, Level $3(20-30 \mathrm{~cm})$ (Figure

4e);

Dimensions: L: $52 \mathrm{~mm}$; W: $35 \mathrm{~mm}(\mathrm{Br})$; NW: - mm; Th: $7.5 \mathrm{~mm}$ (Figure 4e);

Description: Figure $4 \boldsymbol{e}$. The heat-altered chert point fragment has an irregular distal break and a proximal heatfracture which have rendered the tool unclassifiable. The irregular fractures removed most of one blade lateral and the base. One barb remains, but it is fractured by heat damage. Edge retouch is apparent on the remaining lateral. The fragment is thinly biconvex in transverse section.

\section{POSTMONTELl TYPE (1 SPECIMEN)}

Chronological Affiliation: Late Archaic II subperiod

(Johnson 1997:181)

Provenience: Backdirt from the central portion of BHT 'A' (Figure 3f)

Dimensions: L: $38 \mathrm{~mm}$; W: $32 \mathrm{~mm}$; NW: $20 \mathrm{~mm}$; Th: 7 mm (Figure 3f);

Description: Figure 3J: The triangular chert blade has comer-notching high on the lateral edges. The barbs are detached by irregular fractures. There is thinning flake removal on the slightly concave base. The stem is expanding. The distal tip is fractured by an irregular break.

\section{UNIDENTIFIED TYPES (2 SPECIMENS)}

Chronological Affiliation: Prehistoric, Archaic Period Provenience); Test Unit \#5, Level $4(30-40 \mathrm{~cm})$ (Figure 4h); Backdirt collection in central portion of Backhoe Trench 'A' (Figure 4g)

Dimensions: L: $45 \mathrm{~mm}(\mathrm{Br})$; W: $25 \mathrm{~mm}$; NW: $29 \mathrm{~mm}$ (Br); Th: 9 mm (Figure 4g); L: 8.5 mm (Br); W: 14 mm; NW: - mm; Th: $5.5 \mathrm{~mm}$ (Figure $4 \mathrm{~h}$ )

Description: Figure 4g. The triangular blade element of the chert point has its distal tip sheared off by a plunging hinge-fracture. The blade lateral edges are slightly convex. The shoulders are slight and set high on the piece. The stem is wide and is damaged by a possible impact fracture which removed the lateral edge. The point is biconvex in transverse section but somewhat thick at the midline.

Figure $4 \mathrm{~h}$. A hinge-fracture broke the chert point fragment near the distal tip, and another hinge-fracture damaged the stem, removing most of one stem lateral edge. The lateral edges are fairly straight on a subtriangular blade with shallow shoulders. Although one stem lateral is broken, the stem laterals appear parallel. The base is missing due to the hinge-fracture. The tool is biconvex in transverse section. Fine nonpatterned flaking finishes the piece. The lateral edges are noticeably worn.

\section{STemmed Bifaces (Figures 5 AND 6)}

Seven bifaces and biface preforms prepared for hafting are represented in the collection. Figure 5a. has a lanceolate shape with shallow, alternate notching placed low on the haft element. The distal tip is blunt but appears reworked following fracture. The piece is biconvex in transverse section. Basal thinning is present on a slightly concave base.

Figure $5 \boldsymbol{b}$. There is a distal hinge-fractureon the subtriangularblade element. The shoulders are uneven. The stem has somewhat contracting laterals and a concave base. One ear is broken off the stem, and step-fracturing is visible on the blade midline. The blade lateral edges are prepared for thinning. Possible edge wear appears on the stem laterals. The biface is biconvex in transverse section.

Figure 5c. The roughly shaped triangular blade element has a blunt distal tip and a small proximal haft element One barb and one notch is present, while the other lateral edge lacks such treatment. The stem has a fairly straight base with irregular lateral edges. The blade lateral edges show thinning flake removals. The blade surface is step-fractured.The tool is biconvex in transverse section.

Figure 5d. The thick tool is concavo-convex in longitudinal section and biconvex in transverse section. The small haft element has a straight base and a slightly 


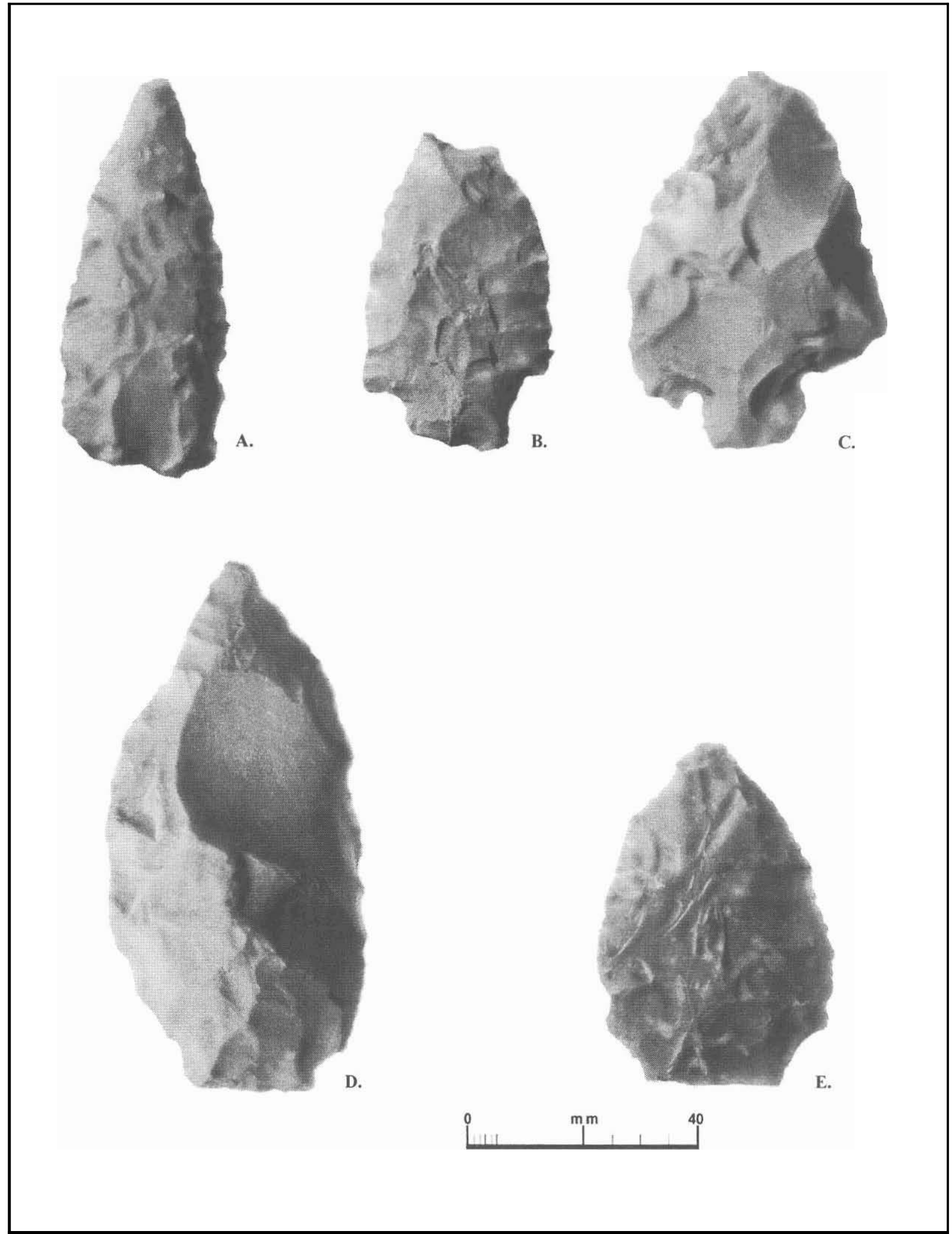

.FIGURE 5. Stemmed bifaces from 4 I WM543, A. stemmedbiface, backdirt, central ponion of BTA'; 
expanding stem formed by notches. There is an impact fracture on the distal tip; edge wear is present on the blade laterals. The blade shape is acuminate.

Figure $\boldsymbol{S e}$. The stemmed biface preform has an ovate shape with a small haft. It is thinly biconvex in transverse section. Notching was started on both lateral edges of the blade, but one comer is snap-fractured proximally. The haft element has a straight base. The blade laterals are biconvex and prepared for edge retouch. The distal tip is blunt.

Figure 6a. Cortex is still present on one face of the biface preform blade. The blade has convex lateral edges with a sharp distal tip. One lateral is covered in cortex. The haft element is convex and rounded. The notches are wide open and low on the sides of the blade. Biconvex in transverse section, the tool is thinned on one face.

Figure $\boldsymbol{6} \boldsymbol{b}$. The preform is roughly reduced bifacially and biconvex in transverse section. The stem has somewhat parallel laterals and a convex base. The distal tip is blunt; the blade laterals are irregularly convex. The lateral edges of the blade are only at the reduction stage.

\section{Knives (Figure 6c)}

One knife fragment was found at 4 1WM543. It is thin and biconvex in transverse section. A medial snap-fracture removed the proximal end of the piece. The laterals show fine edge retouch with some edge rounding.

\section{B i f a c e Fragments (Figures 7 and 8)}

A total of 31 generalized biface fragments and biface preform fragments were collected. As one can see in the illustrations, many of the bifaces are too fragmentary to analyze in detail. Most of the bifaces were found in the backdirt of Backhoe Trench 'A' and in the upper levels of Test Unit \#4. All of the bifacial tools presented in Figures 7 and 8 are fragmentary. A selected number of the bifaces are described as examples.

Figure 7d. A heat-altered biface preform with a subtriangular shape, the tool has heavy step-fracturing on its lateral edges. The remnant of the base is unfinished. Thin and biconvex in transverse section, most of one face was removed by heat-fracturing.

Figure $7 g$. The biface preform is thin but still retains cortex on one face. The piece, though bifacially reduced, is flake-like due to the concavo-convex shape in longitudinal section. Broken by a hinge-fracture, the fragment may have suffered its damage during manufacture.

Figure 7i. The preform has cortex present on one face. A medial hinge-fracture broke the tool transversely. Thickly biconvex, the rectangularly shaped tool has lateral thinning flake removal.

Figure 8a. Thinly biconvex in transverse section, the fragment is medially hinge-fractured.The base is straight. Edge rounding is apparent on the somewhat regular lateral edges.
Figure $8 c$. The preform is broken at one end by a hinge-fracture. One face is reduced over two-thirds of its surface by one large flake removal. The tool does not resemble a scraper, however. The lateral edges are prepared for retouch. The biface is plano-convex in transverse section.

Figure 8d. Biconvex in transverse section, the biface fragment is concavo-convex in longitudinal section. It is hinge-fractured medially. The remaining end is blunt. The thick tool is heavily step-fractured.

\section{R etouched Flakes (Figure 9)}

Eleven retouched flakes were recovered from the site. One retouched core fragment, three faceted secondary flakes (Figure 9a), one unfaceted secondary flake, two tertiary flake fragments (Figure 9b), two faceted tertiary flakes (Figure 9c), and two unfaceted tertiary flakes (Figure 9d) were used as expedient tools.

\section{Burins (Figure 10a)}

One burin was found in the backdirt at the north end of Backhoe Trench ' $\mathrm{A}$ '. The tool is a biface preform broken by hinge-fractures on both ends. Cortex is still present on one face. The preform has lateral edges which are prepared for reduction, but the left dorsal lateral is still quite thick. Although the burin has a flake-like appearance, it is biconvex in transverse section. The burin blows on one end meet at a $90 \%$ angle, with one lateral detachment and one transverse removal. The preform looks heat-affected.

\section{Gouges (Figure 10B)}

A gouge was collected from the fill outside the ashy concentration. The piece does not conform to the traits which characterize Guadalupe gouges, but there is a definite working edge on one end. The rectangular tool is bifacially reduced with irregularly parallel lateral edges and a slightly convex base.

\section{SCRAPERS (Figure 10C)}

Only one scraper was identified in the collection. A secondary unfaceted flake has nonconverging edge retouch on the dorsal distal end. The edge angle is 50\%. The retouch is step-fractured, and edge wear is present.

\section{Utilized Blades and Flakes (Figure 10)}

A total of 77 utilized flakes and blades were found at the site. Table 5 describes the secondary and tertiary flakes with utilization and the location on the flake where utilization scars were apparent. Tertiary flakes accounted for almost all of the total at $84.4 \%$ or 65 flakes. Of the tertiary flakes, most of those with utilization were flake fragments (42.8\%). Only two of the utilized pieces are blades (Figure 10e-f). 


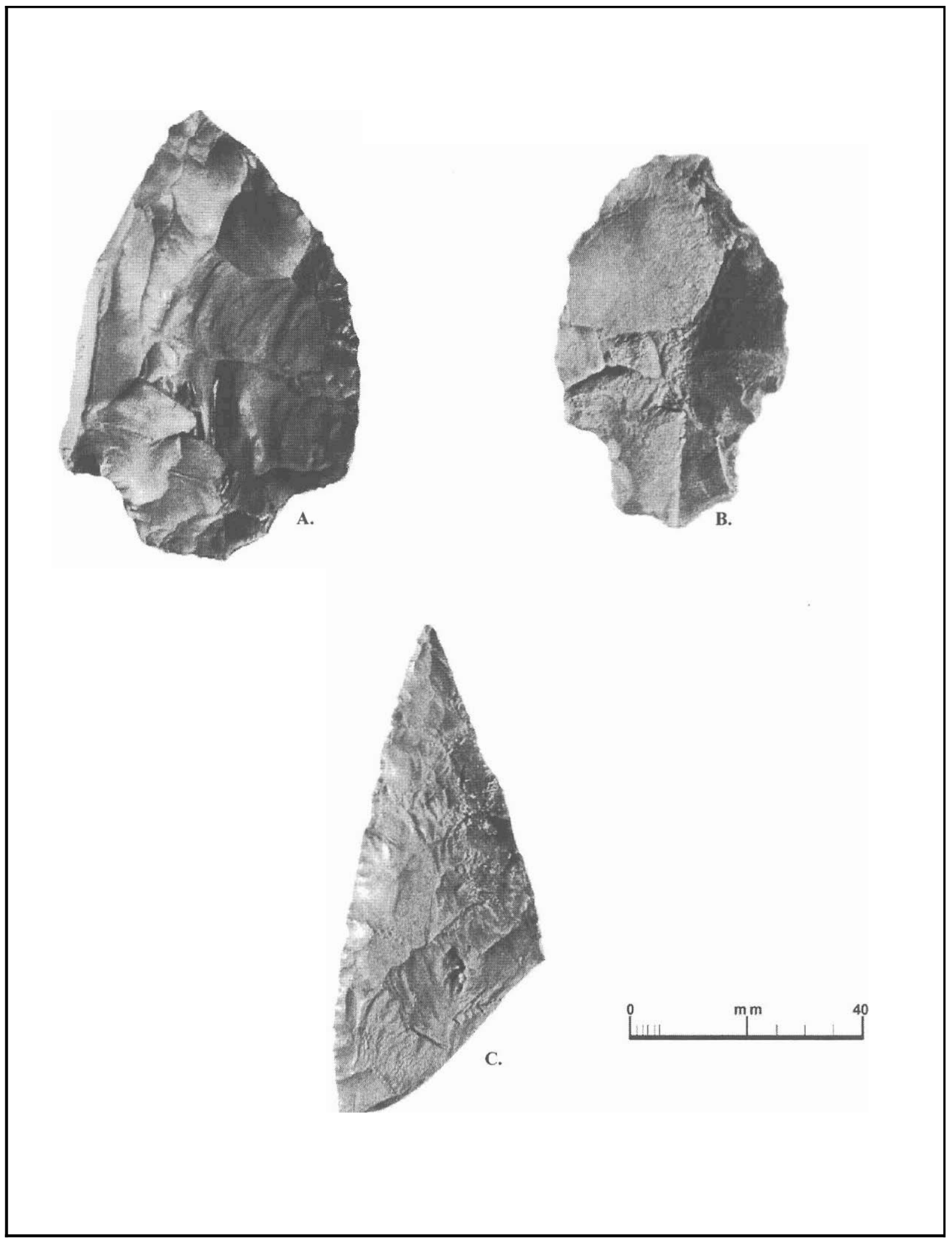

FIGURE 6. Stemmed bifaces and knives from 41 WM 543. A, B, stemmed biface preforms. surface collection: C. knife fragment backdirt collection at north end of Backhoe Trench 'A'. 


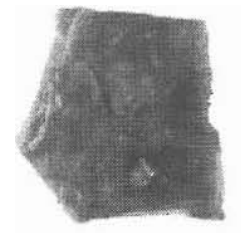

A.

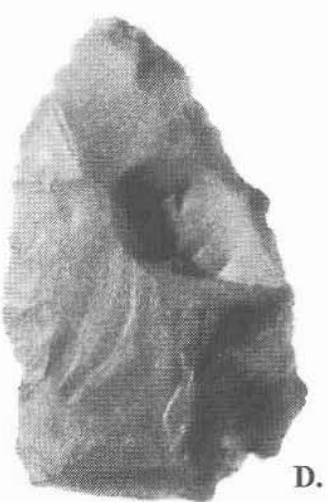

D.

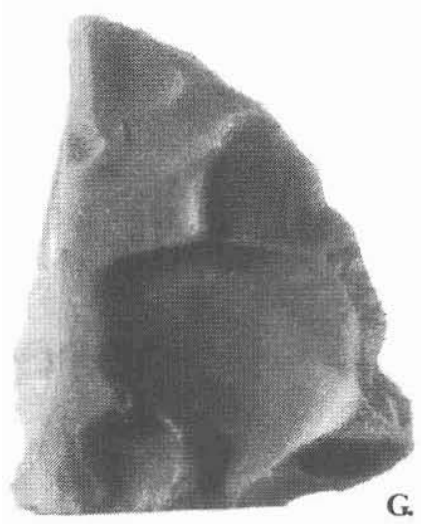

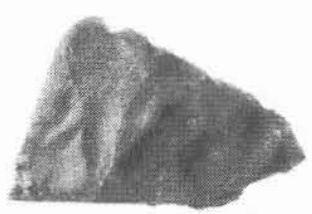

B.

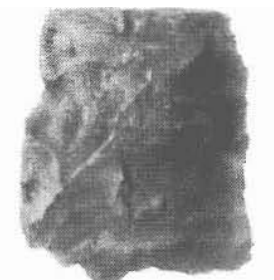

C.

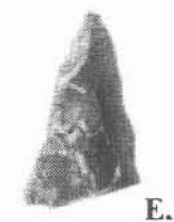

E.

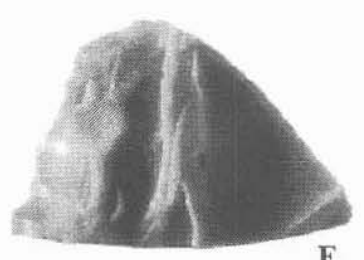

F.
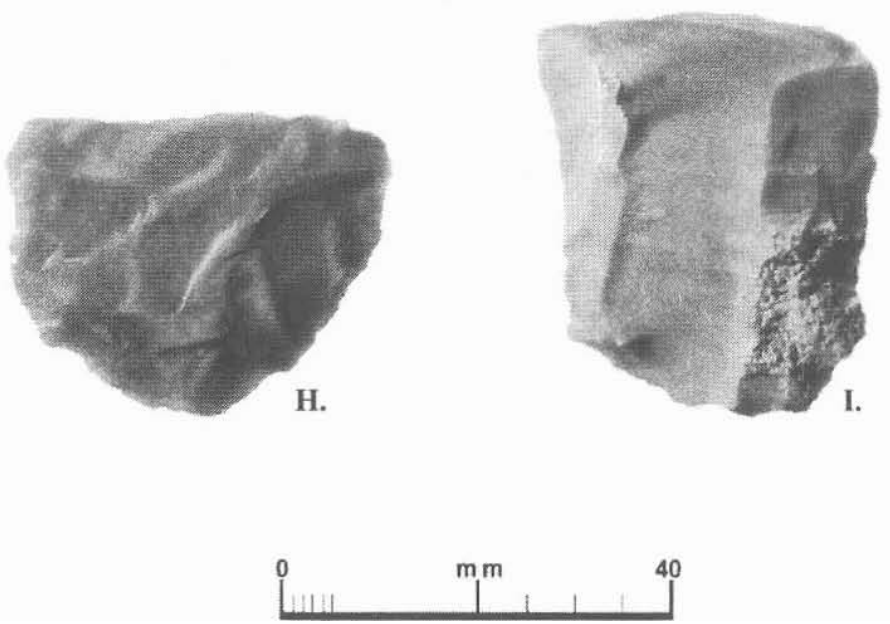

FIGURE 7. Biface fragments collected at 41WM543. A - C, bifaces. backdirt at central portion of Backhoe Trench 'A'. D. biface preform backdirt central portion of B HT'A E. biface. Test Unit \#5.Level 4 (30-40cm): F. G biface preforms. backdirt at north end of BHT 'A': H. biface, Test Unit \#4. Level I $(0-10 \mathrm{~cm})$ : I; biface preform. surface collection. 

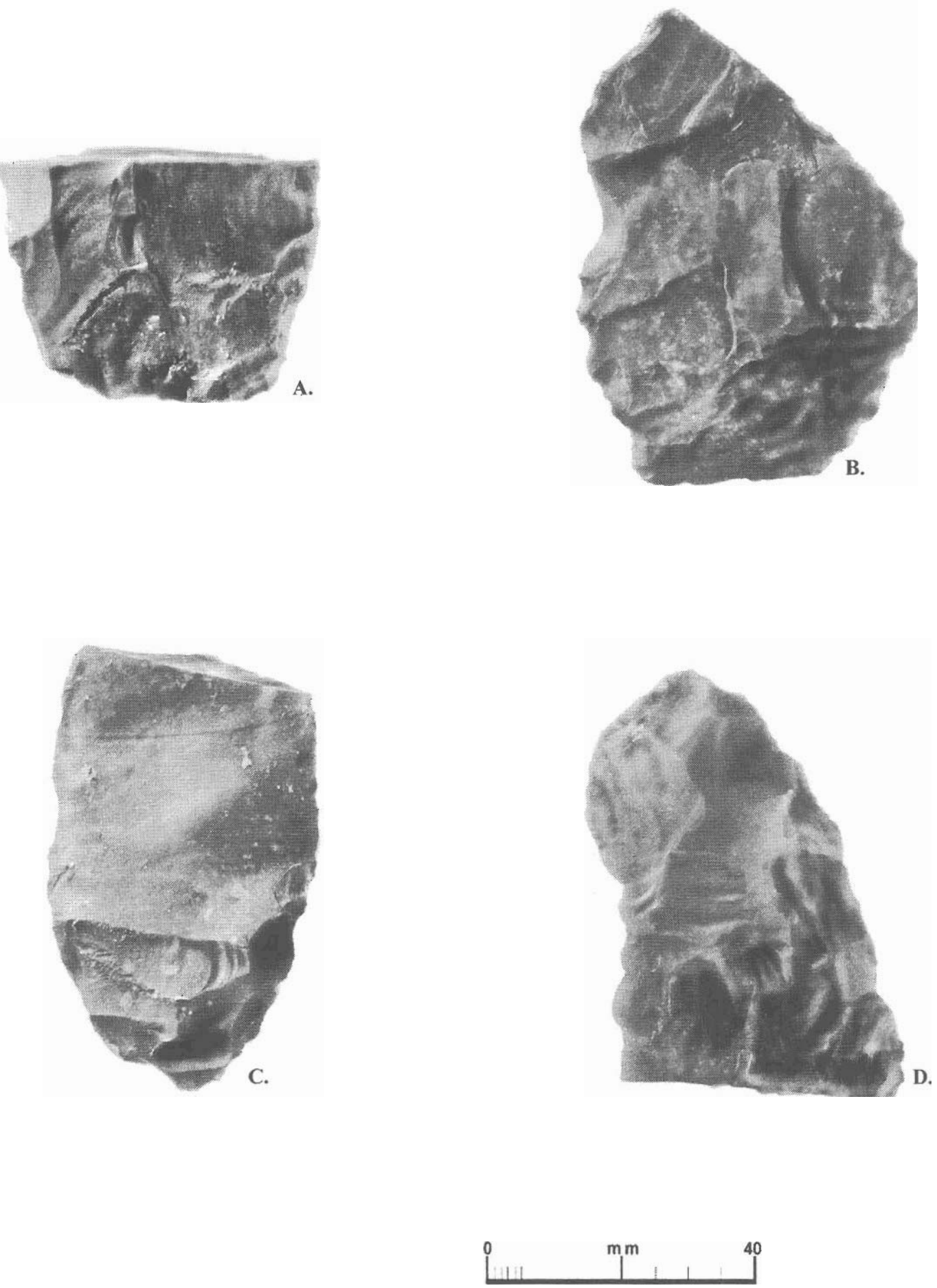

FIGURE 8. B iface fragments from 41WM543. A. biface platform. backdirt at north end of BT 'A': B. biface preform; TU3. level $4(30-40 \mathrm{~cm})$ : C, biface preform, surface collection: D_biface. backdirt central portion of BT 'A'. 


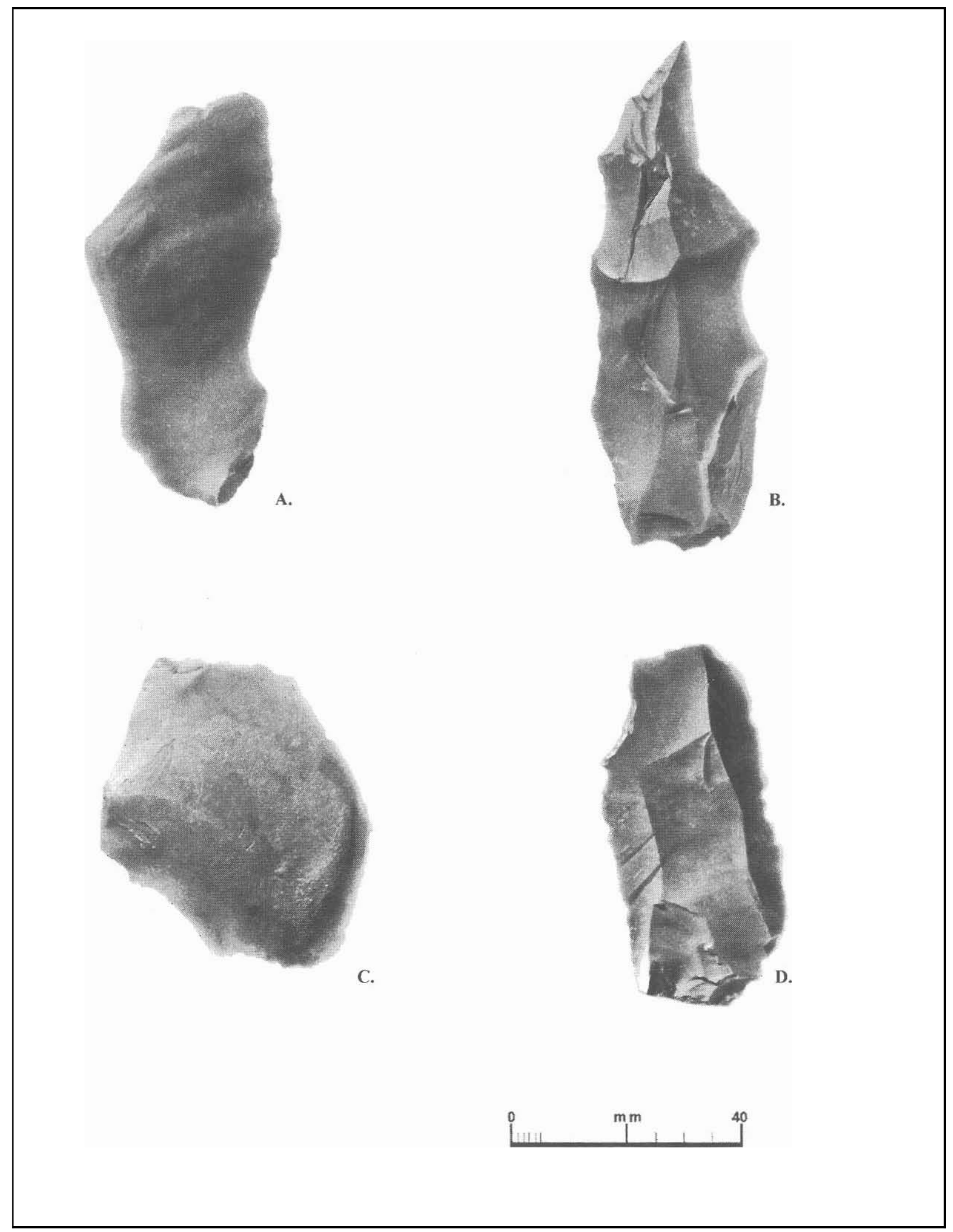

FIGURE 9. Retouched flakes from 41 WM543. A - C. backdirtcollection: RT 'A'; D, surface collection. 


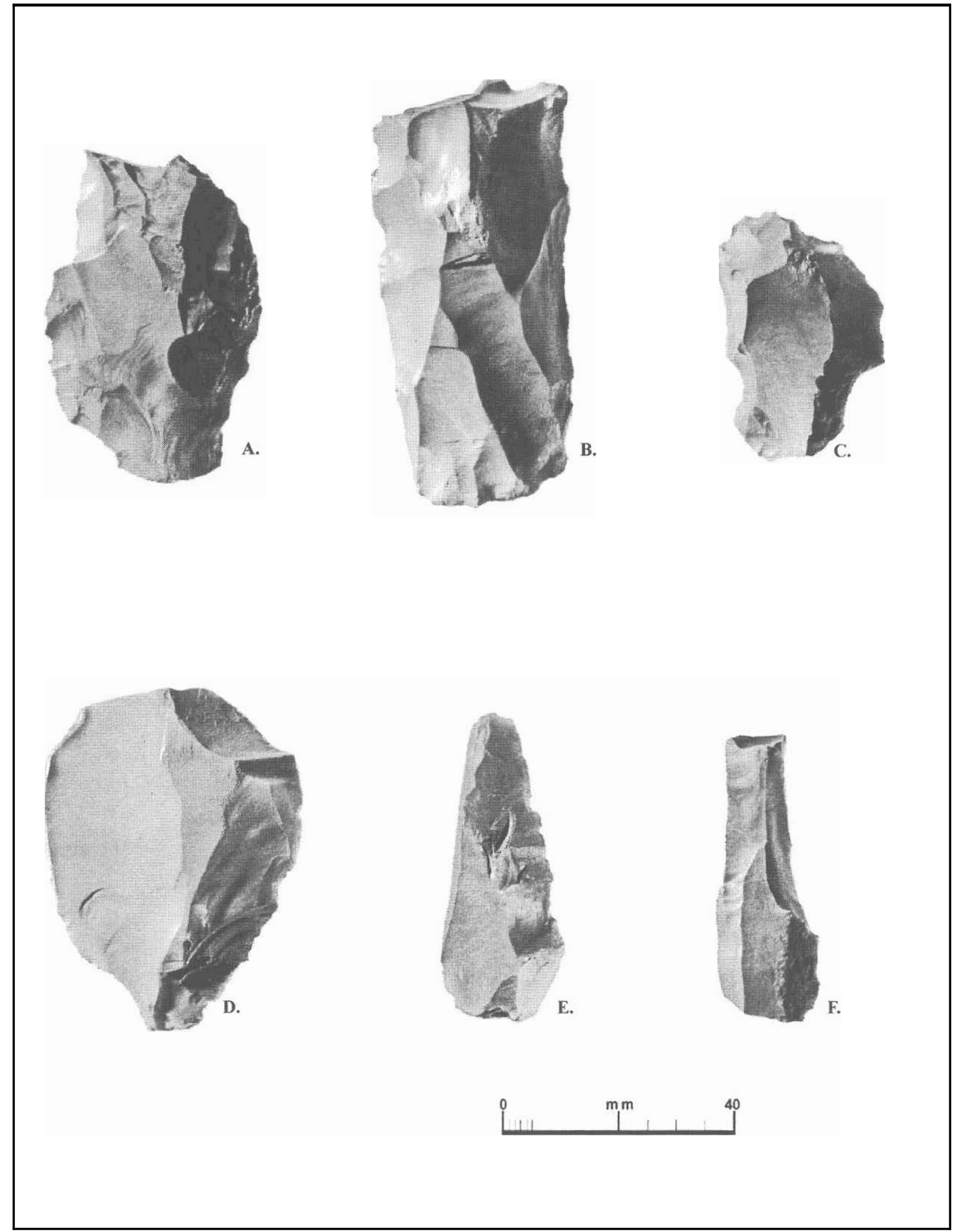

FIGURE 10. miscellaneous tools from 41WM543. A. burin on biface preform. backdirt at north end of BT "A";B. gouge, TU3. level $2(10-20 \mathrm{~cm})$ outside ash concentration: C. scraper. TU5, level $2(10-20 \mathrm{~cm})$ : D. utilized flake, TU3. level $4(30-40 \mathrm{~cm})$ : E. F. utilized flakes. backdirt at north end of BT 'A'. 


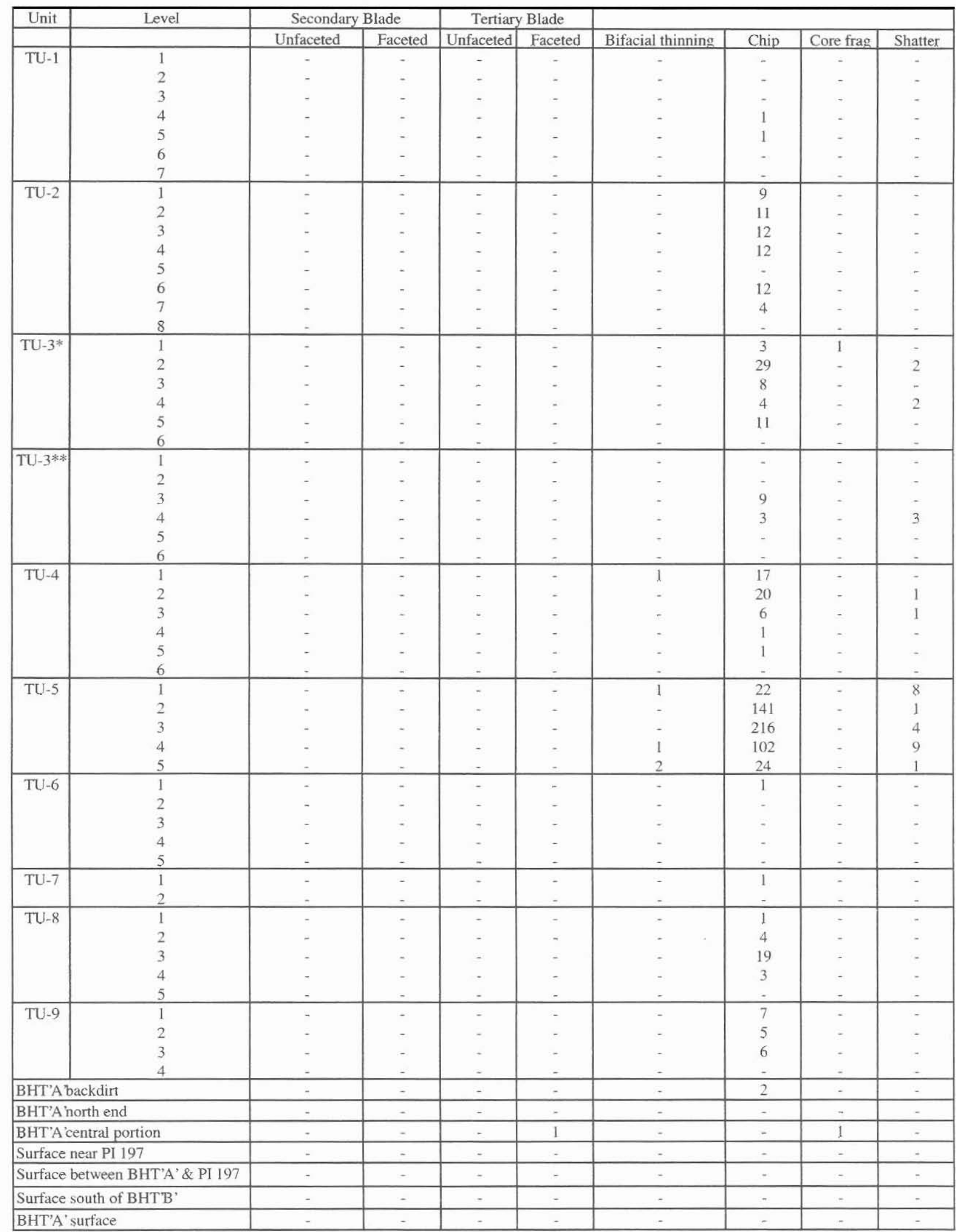

* Outside the ash concentration

** Within the ash concentration

TABLE 4. Blades and other chipping debris from 41WM543 


\begin{tabular}{|l|c|c|c|c|c|c|c|}
\hline \multicolumn{1}{|c|}{ Location of utilization } & \multirow{2}{*}{ Blade } & \multicolumn{3}{c|}{ Secondary flake } & \multicolumn{3}{c|}{ Tertiary flake } \\
\cline { 3 - 8 } & & Unfac & Fac & Frag & Unfac & Fac & Frag \\
\hline Ventral left lateral & - & - & - & - & 4 & I & 4 \\
\hline Ventral right lateral & - & - & - & - & 3 & 2 & 7 \\
\hline Vental distal end & - & - & - & - & 1 & - & 2 \\
\hline Ventral proximal end & - & - & - & - & 1 & - & - \\
\hline Vental left and right laterals & - & - & - & - & - & 1 & - \\
\hline Vental left lateral and distal end & - & - & - & - & 1 & 1 & - \\
\hline Vental right lateral and distal end & - & - & - & - & - & - & 3 \\
\hline Dorsal left lateral & 1 & 1 & - & 2 & 6 & 3 & 7 \\
\hline Dorsal right lateral & - & 1 & 1 & - & 2 & 1 & 2 \\
\hline Dorsal distal end & - & 2 & - & 1 & 1 & - & 4 \\
\hline Dorsal proxomal end & - & - & - & - & 1 & - & - \\
\hline Dorsal left and right laterals & - & - & - & - & 2 & 1 & 2 \\
\hline Dorsal left lateral and distal end & - & - & - & - & 1 & - & - \\
\hline Dorsal right lateral and distal end & - & 1 & - & - & - & - & 2 \\
\hline Unidentifiable & - & - & - & - & - & - & - \\
\hline
\end{tabular}

TABLE5. Utilization scars on flakes

\section{RECOMMENDATIONS}

Only the utilized flakes were found distributed throughout the levels in the test units. The other tools tend to occur in Levels 1 to 4 . Based on the tool and debitage counts, one could characterize the cultural deposition as above $50 \mathrm{~cm}$. Of the diagnostic projectile points, most of the points were found on the surface or in a disturbed context of backdirt from the trenches. In the test units, Level 3 contained points identified by Dr. Johnson as Early Archaic, Middle Archaic, and Late Archaic I subperiod. The possible Andice and a Middle Archaic Untyped were found in the same unit. Similarly, Level 4 produced both Early Archaic and Middle Archaic points, with a Middle Archaic Untyped and a Nolan in the same unit. The backhoe trench and the two test units all were at the same elevation.

It is unfortunate that testing failed to identify any features, as that leaves only the projectile point collection upon which to base site chronology. If one relies on the point placement, it seems that the excavated levels show mixing of cultural deposits in this area of the site. No diagnostics were found below $40 \mathrm{~cm}$ bgs.
When testing began, the ground surface was already disturbed by clearing and grubbing activities to remove trees from the drill locations. In spite of the disturbance, the nine test units and two backhoe trenches excavated at the portion of the site within the right-of-way identified subsurface cultural deposition. The area of the low knoll contained evidence of an Early to Late Archaic occupation. Only lithic artifacts were recovered, however. No features were found during the testing.

It is believed that the site area tested offers little potential for intensive research into the Central Texas Archaic. Analysis of the testing results at 41 WM543 suggests that more work inside the right-of-way is not justified at the site. The small concentration of burned rock did not yield charcoal or faunal samples for use in site interpretation. Further excavation within the right-ofway will only allow the collection of more artifactsin a disturbed context.

The portion of 41 WM543 inside the right-of-way does not meet the criteria for eligibility to the National Register of Historic Places. These recommendations do not extend to the rest of the site unaffected by the Parmer Lane project, however. 


\section{References Cited}

Blair, W. Frank

1950 The Biotic Provinces of Texas. Texas Journal of Science 2(1):93-117.

Coffman, Robert J., Martha Doty Freeman, and Ross

C. Fields

1985 Inventory and Assessment of Cultural

Resources at the Ideal Basic Tract, Williamson County. Texas. Reports of Investigations no. 38. Prewitt \& Associates, Inc.. Austin.

Enquist, Marshall

1987 Wildflowers of the Texas Hill Country. Lone Star Botanical, Austin.

Fox, Daniel E. and W. Hayden Whitsett

1984 Archeological Reconnaissancealong South Brushy Creek near the City of Cedar Park. Williamson County, Texas. Prepared by the Texas Department of Water Resources, Document C-48-1524.

Garner, L.E. and K.P. Young

1976 Environmental Geology of the Austin Area: A n A id to Urban Planning. Report of Investigationsno. 86. Bureau of Economic Geology, University of Texas at Austin.

Gilmore, Kathleen Kirk

1969 The San Xavier Missions: A Studv in Historic Site Identification. State Building Commission Archeological Program report no. 16. Austin, Texas.

Girard, Jeffrey S.

1984 Archeoloaical Assessments at the Cedar Park Mound. 4IWM8. in ButtercupCreek Subdivision, Williamson County. Texas. Letter report no. 261. Prewitt and Associates, Inc. Austin, Texas.

Gould, F. W.

1978 Common Texas Grasses: An Illustrated Guide. Texas A\&MUniversity Press, College Station.
Hays, T. R. (ed.)

1982 Final R eport:Archaeological Investigations at the San Gabriel Reservoir Districts, Central Texas. Volumes I and II. Submitted to the U.S. Army Corps of Engineers. Institute of A pplied Sciences, North Texas State University, Denton.

Johnson, LeRoy

1997 The Lion Creek site (41BT105): Aboriginal Houses and Other Remains at a Prehistoric Rancheria' in the Texas Hill Country (Burnet County). Texas Department of Transportation Archeology Studies Program Report 1; Office of the State Archeologist, Report 41. Austin.

Mercado-Allinger, Patricia A. and Crystal Sasse Ragsdale

1984 Inventorv and Assessment of Cultural Resources. Jamail property development, Williamson County. Texas. Report of Investigations no. 28. Prewitt and Associates, Inc., Austin.

Pearce, J.E.

1919 Indian Mounds and Other Relics of Indian life in Texas. American Anthropologist, 2 1(3):223-234.

1929 Cedar Park Mound. Field notes on file. Texas Archeological Research Laboratory. Austin, Texas.

1932 The Present Status of Texas Archeology. Bulletin of the Texas Archeological and Paleontological Society, 4:44-54.

Prewitt, Elton R.

1981 Cultural Chronology in Central Texas. Bulletin of the Texas Archeological Society, 25:65-69.

1983 From Circleville to Toyah, Comments on Central Texas Chronology. Bulletin of the Texas ArcheologicalSociety, 54:201-238. 
Prikryl, Daniel J.

1990 Lower Elm Fork Prehistory: A Redefmition of Cultural Concepts and Chronologies along the Trinity River. North Central Texas.Office of the State Archeologist, Report 37. Austin.

Scarborough, Clara Stearns

1973 Land of Good Water: A Williamson County Texas History. Williamson County Sun Publishers, Georgetown, Texas.

Schuetz, Mardith K.

1957 Report on Williamson County Mound Material. Bulletin of the Texas Archeological Society, 28:135-168.

Smith, Laurel and John Jameson

1986 Updated site form for 41WM543. Brushy Creek WCID utility easement survey. Espey-Huston \& Associates document no. 860649, Austin.

Suhm, Dee Ann and Edward B. Jelks

1954 An Introductory Handbook of Texas Archeology. Bulletin of the Texas Archeological Society, no. 25.
1962 Handbook of Texas A rchaeology: Type Descriptions.The Texas Archeological Society and The Texas Memorial Museum, Austin.

1960 A Review of Central Texas Archeology. Bulletin of the Texas Archeological Society, 29:63-107.

Turner, Ellen Sue and Thomas R. Hester

1985 A Field Guide to Stone Artifacts of Texas Indians. Texas Monthly Press, Austin.

Webb, Walter Prescott

1952 The Handbook of Texas. Volume 11. Texas State Historical Association, Austin, Texas.

Weir, Frank A.

1976 The Central Texas Archaic. Unpublished doctoral dissertation, Washington State University, Pullman.

Werchan, Leroy E. and John L. Coker

1983 Soil Survey of Williamson County. Texas. United States Department of Agriculture, Soil Conservation Service. General Printing Office, Washington, D.C. 
APPENDIX A

Test Unit Wall Profiles 


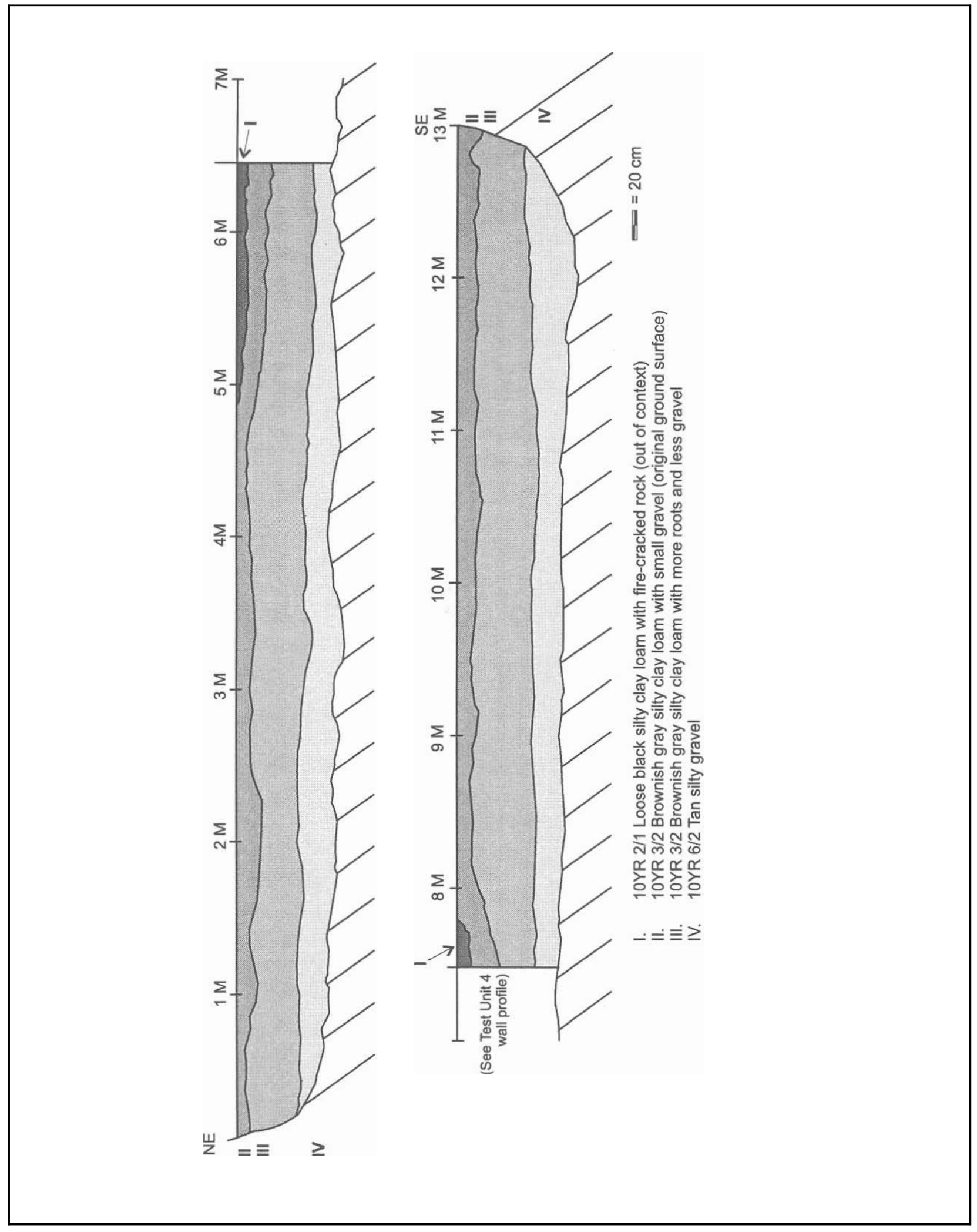

1. Profile of Backhoe Trench 'A'. east wall. 

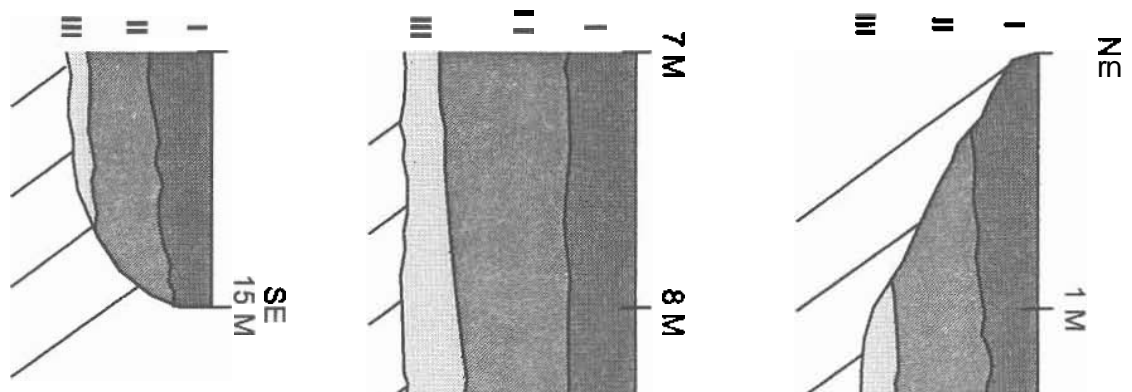

$=-$

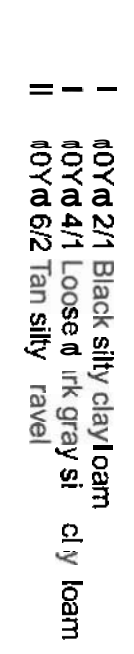

.
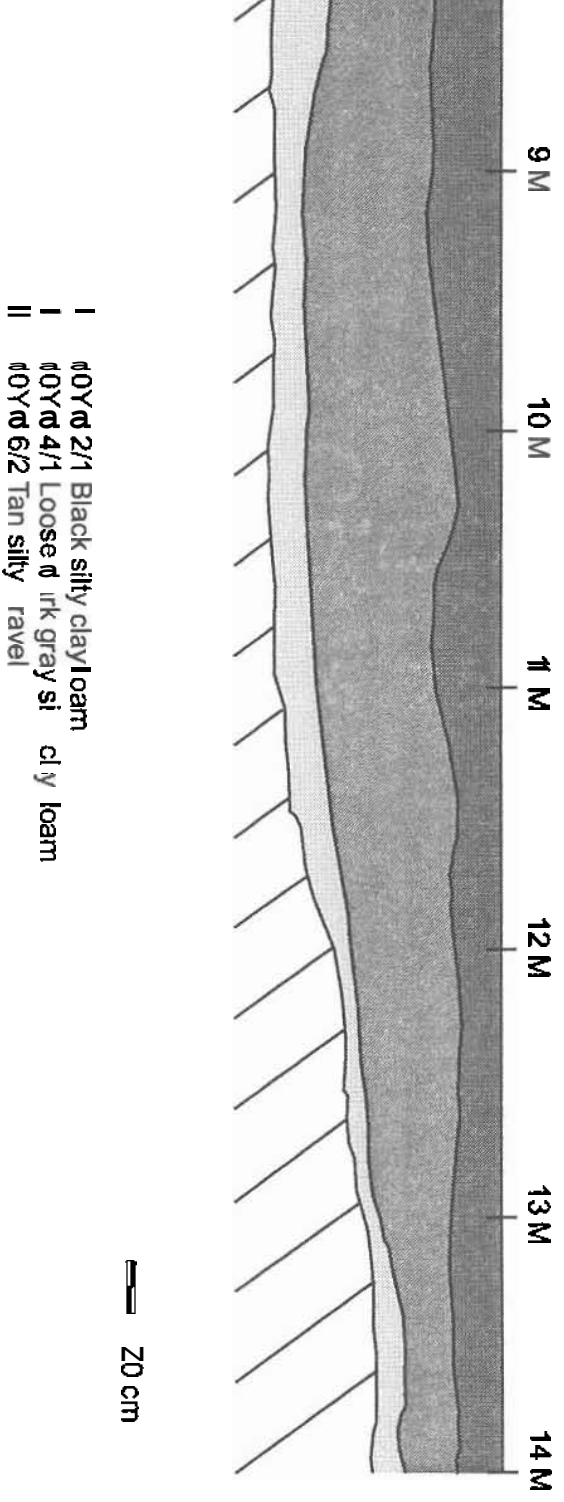

$\leq$

$-\overrightarrow{0}$

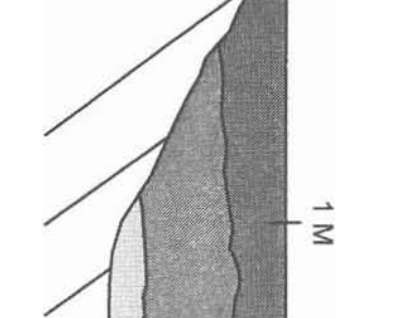

$\stackrel{0}{3}$
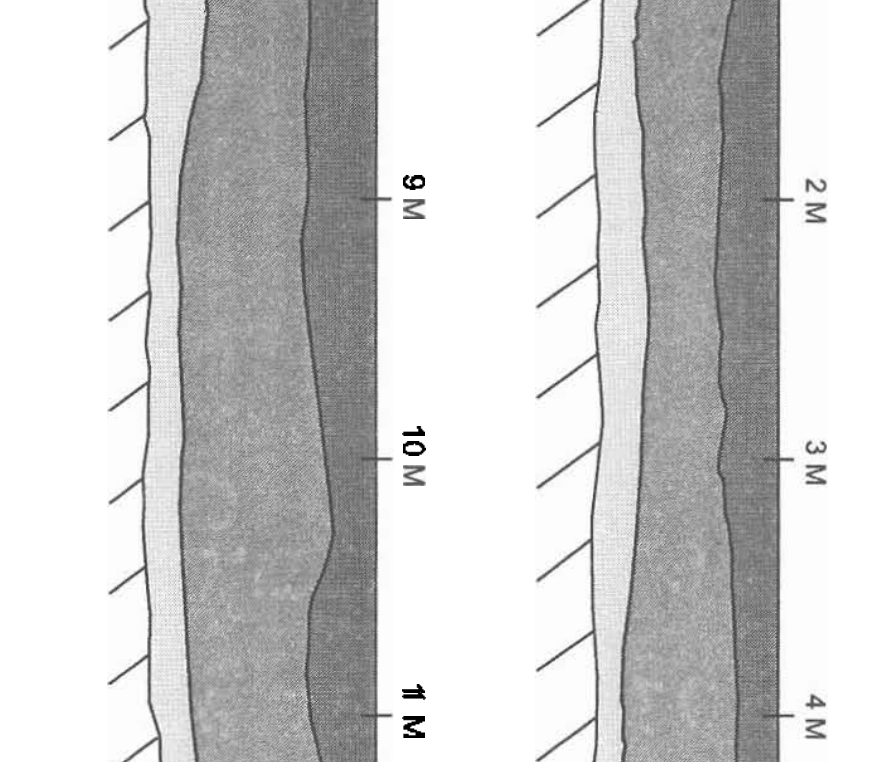

$\overrightarrow{3}$

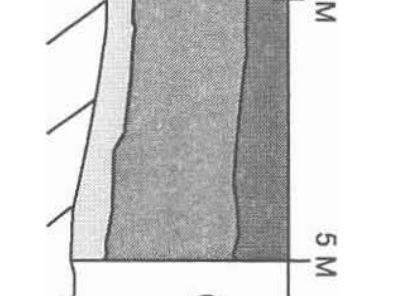

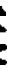

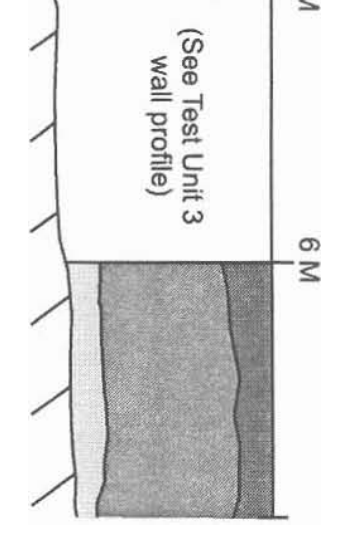

2. Profile of Backhoe Trench 'B'. east wall. 


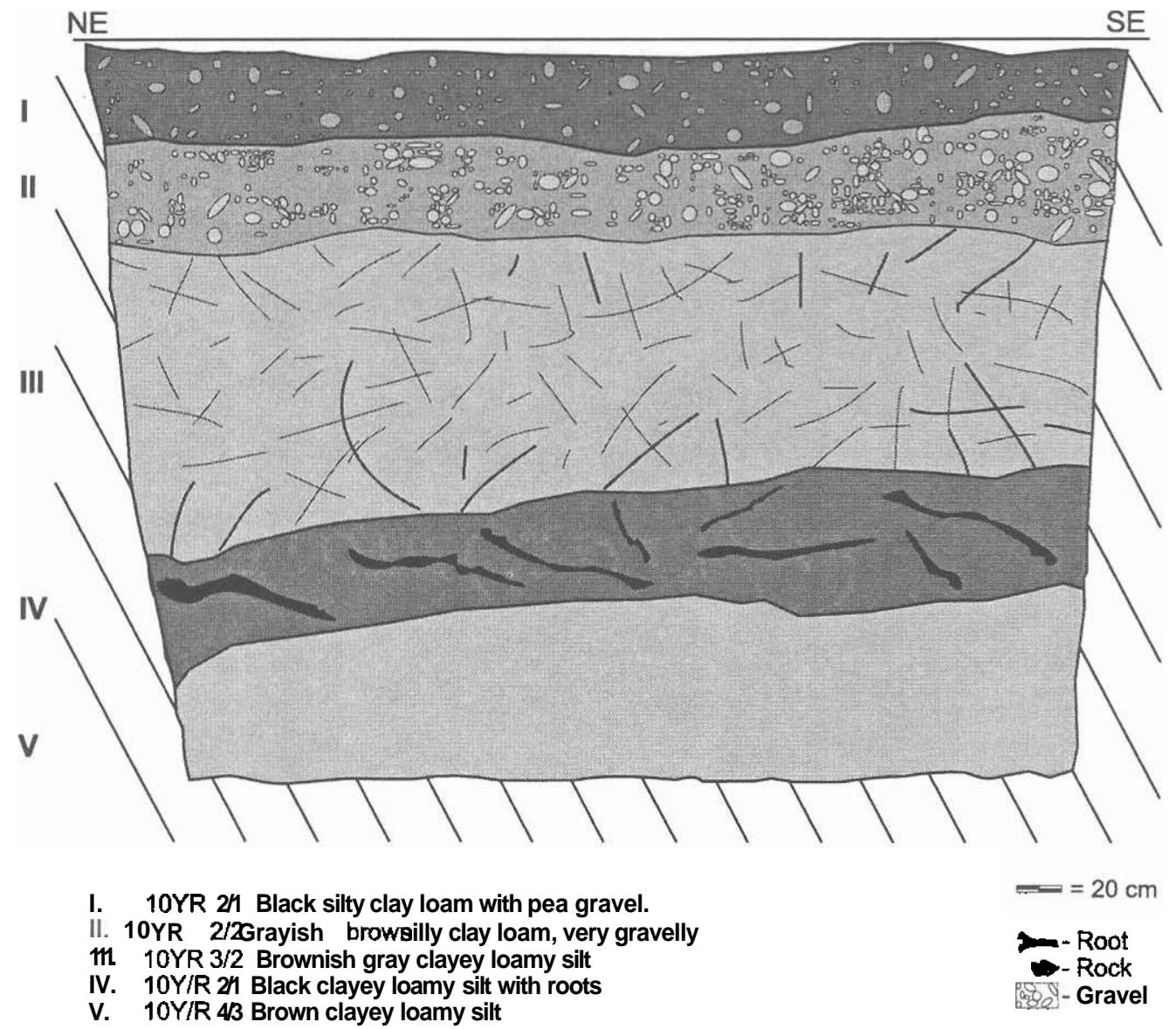

3. East wall profile of Test Unit I 


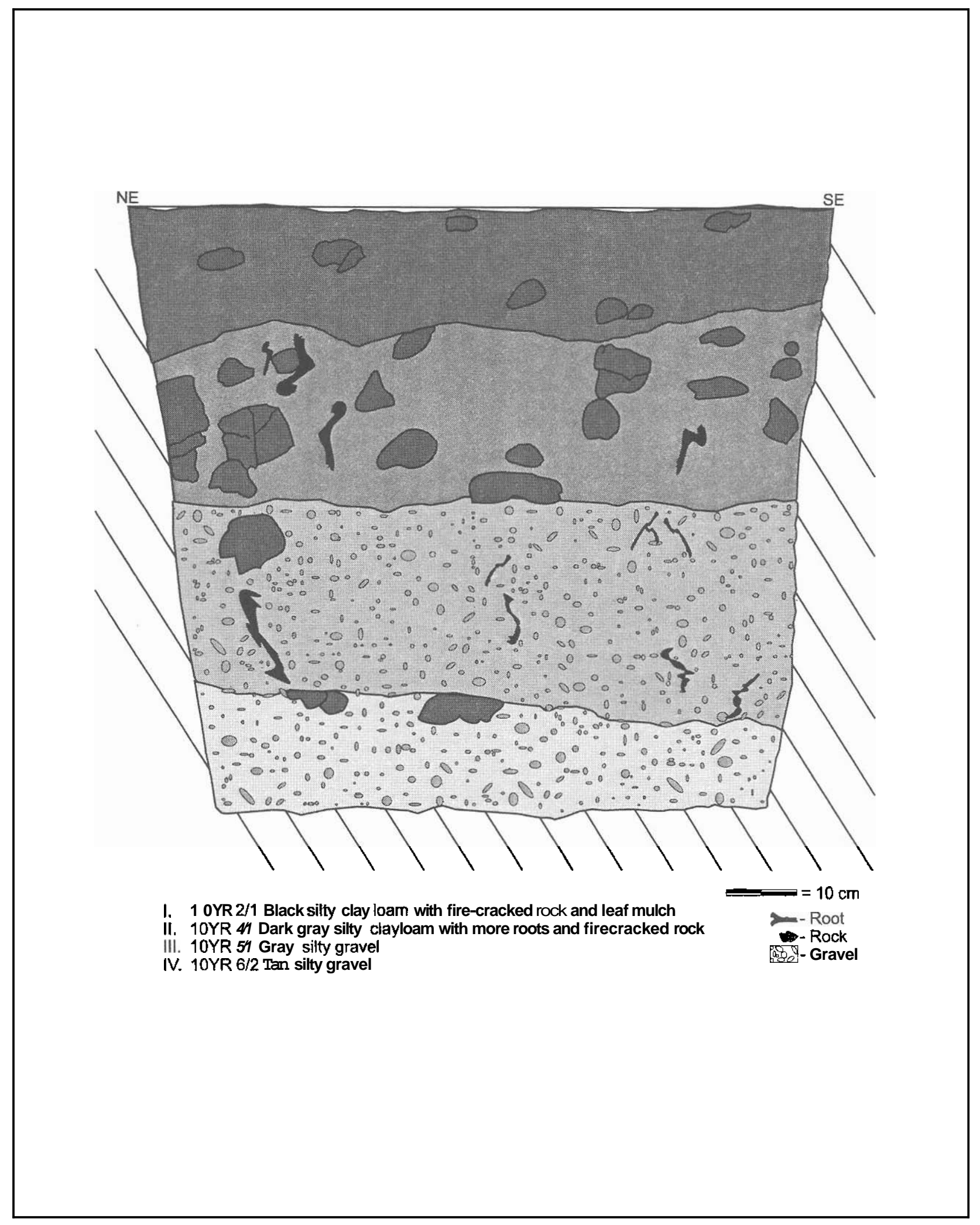

4. East wall profile of Test Unit 2. 


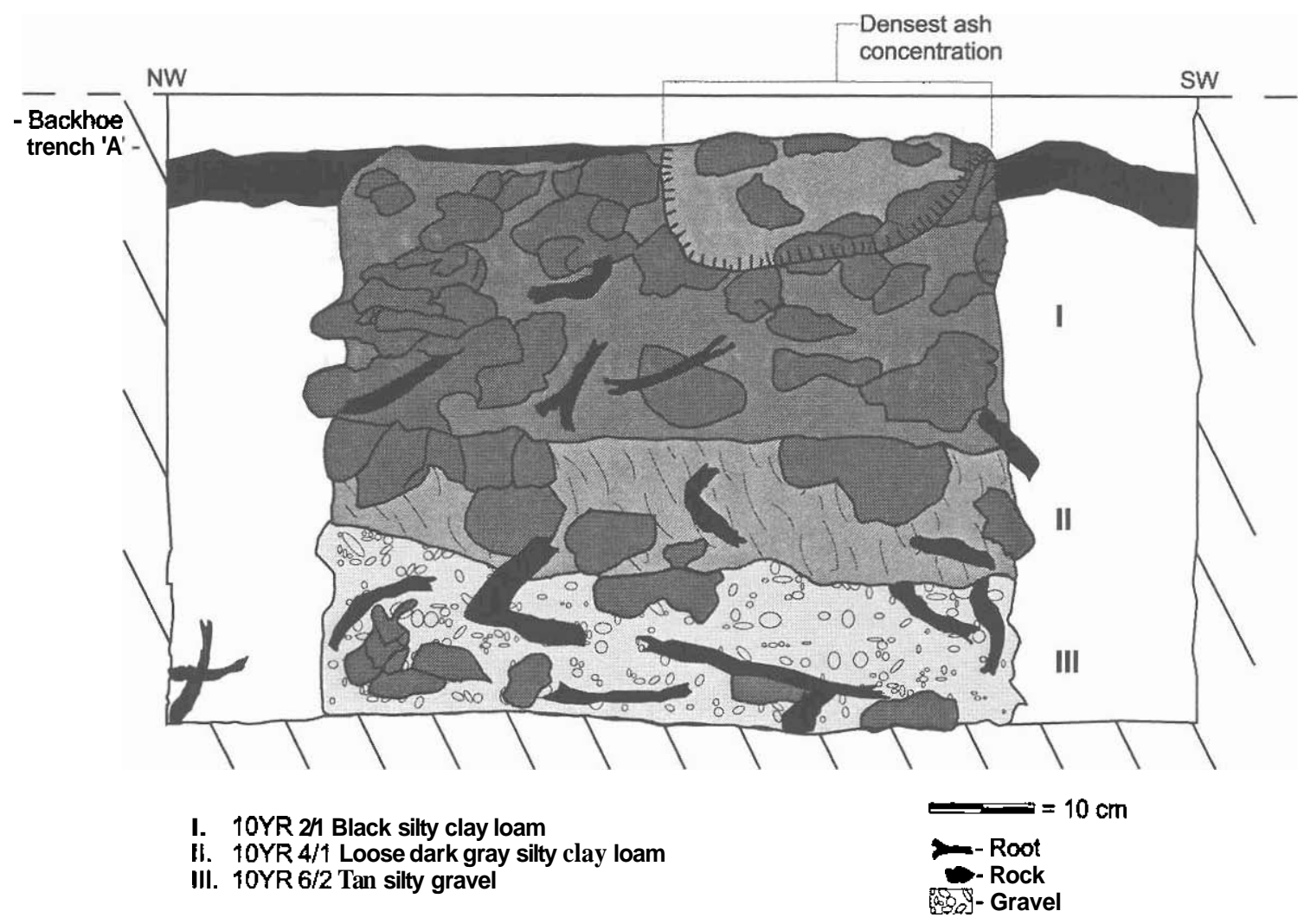

5. West wall profile of Test Unit 3. 


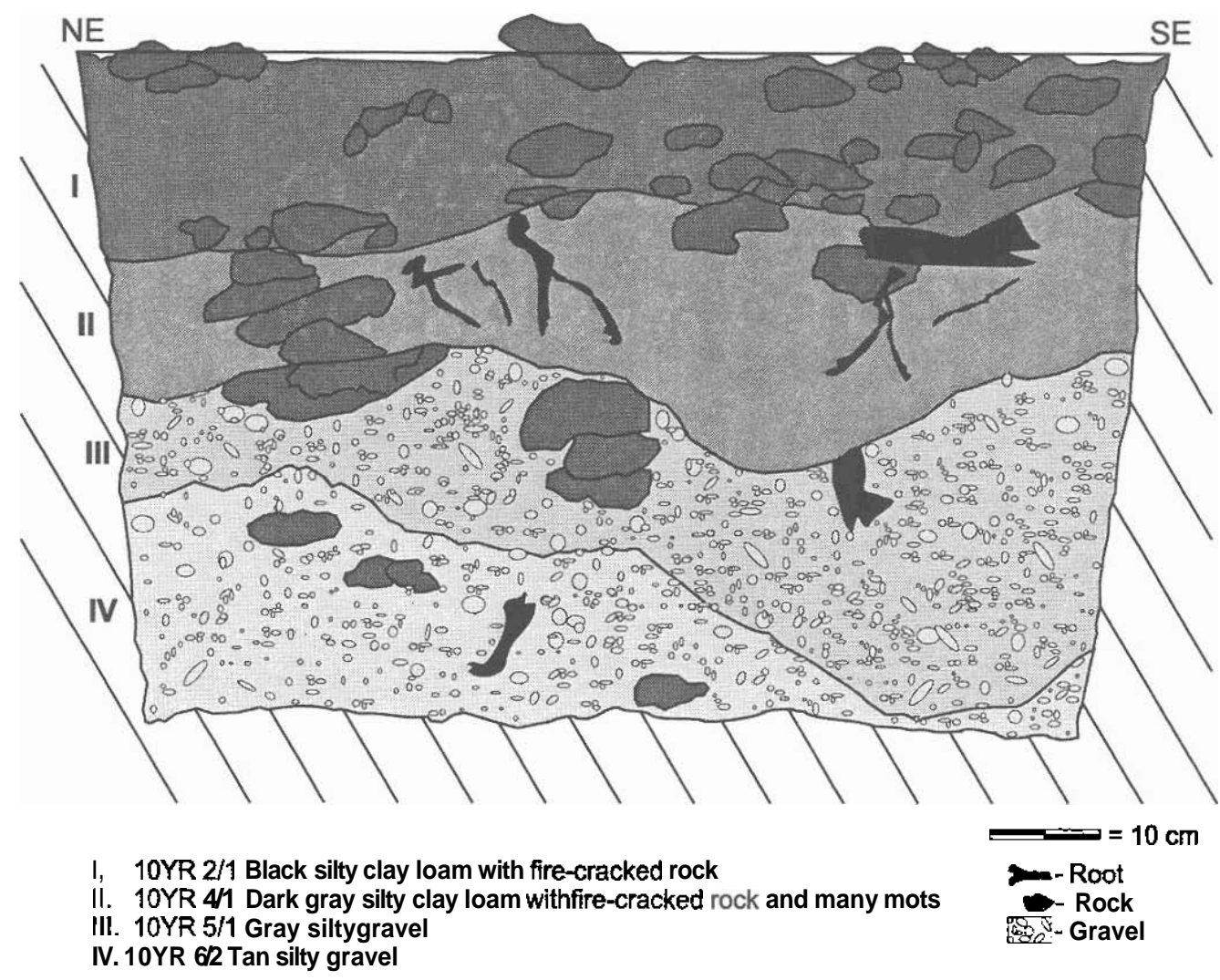

6. East wall profile of Test Unit 3. 


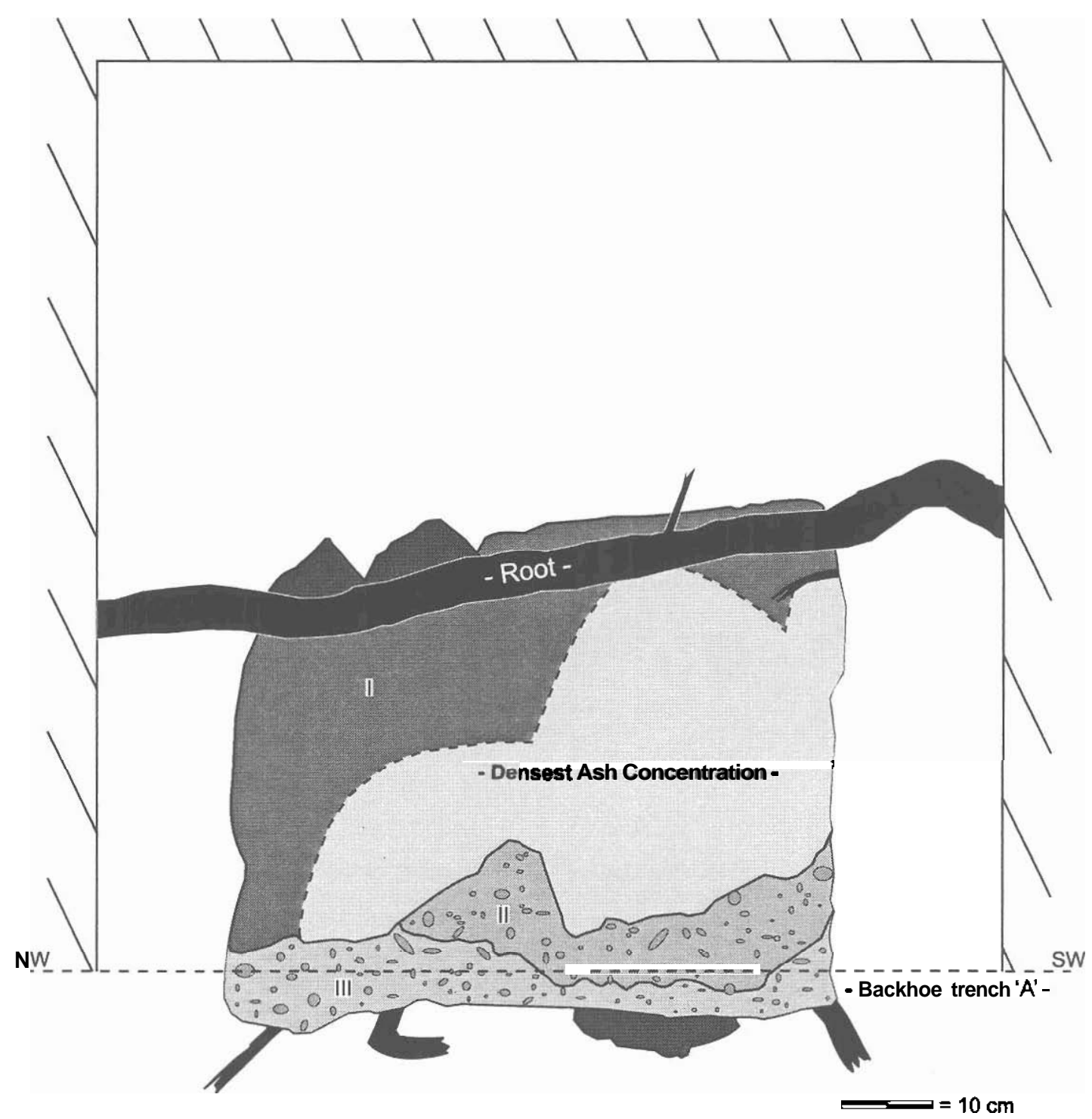

I. 10YR 2/ Black silty c lay loam with fire-cracked rock

II. 10YR $5 / 1$ Gray silty gravel

III. 10YR $6 / 2$ Tan silty gravel

7. Plan view of ash concentration in Test Unit 3. 


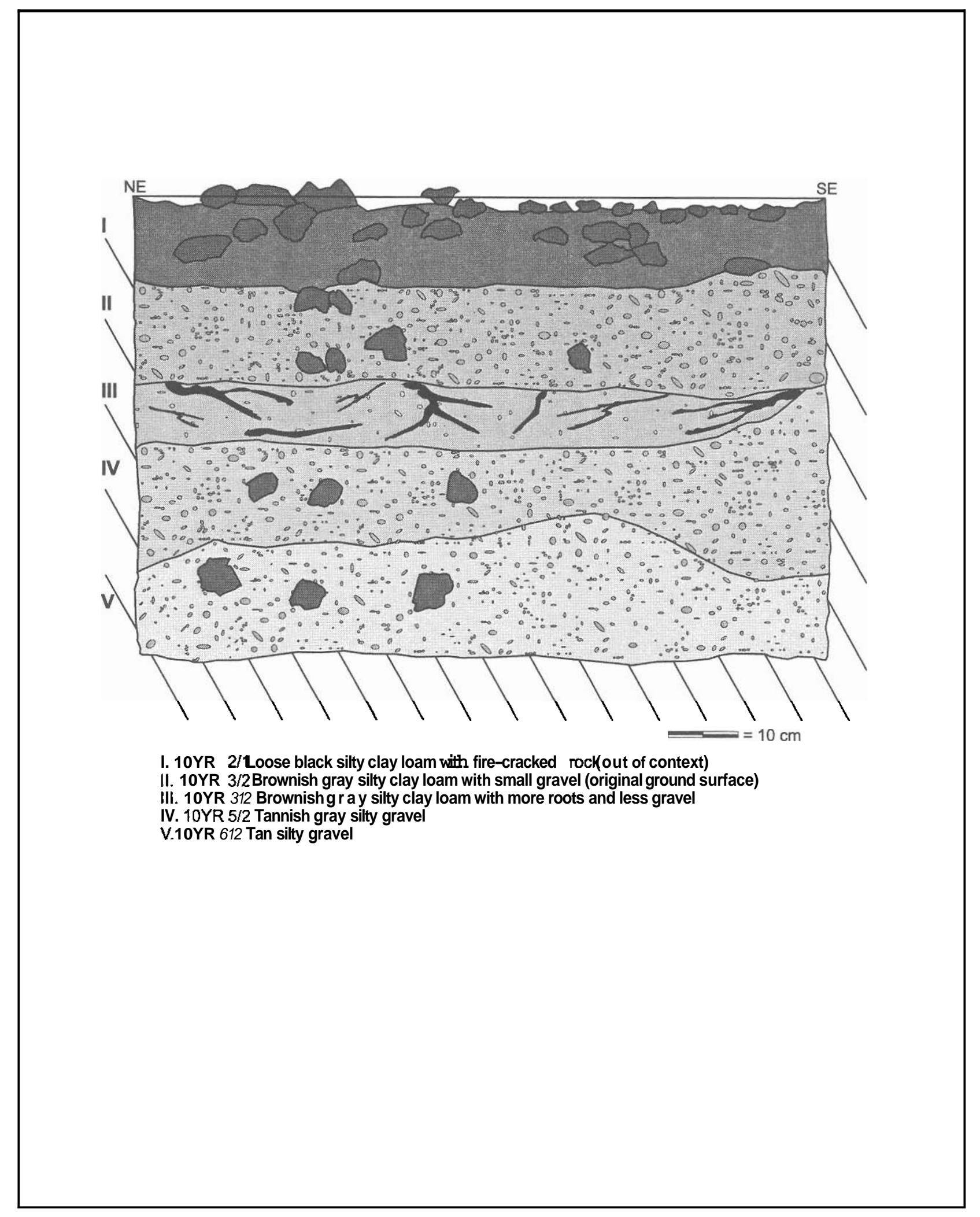

8. East wall profile of Test Unit 4. 


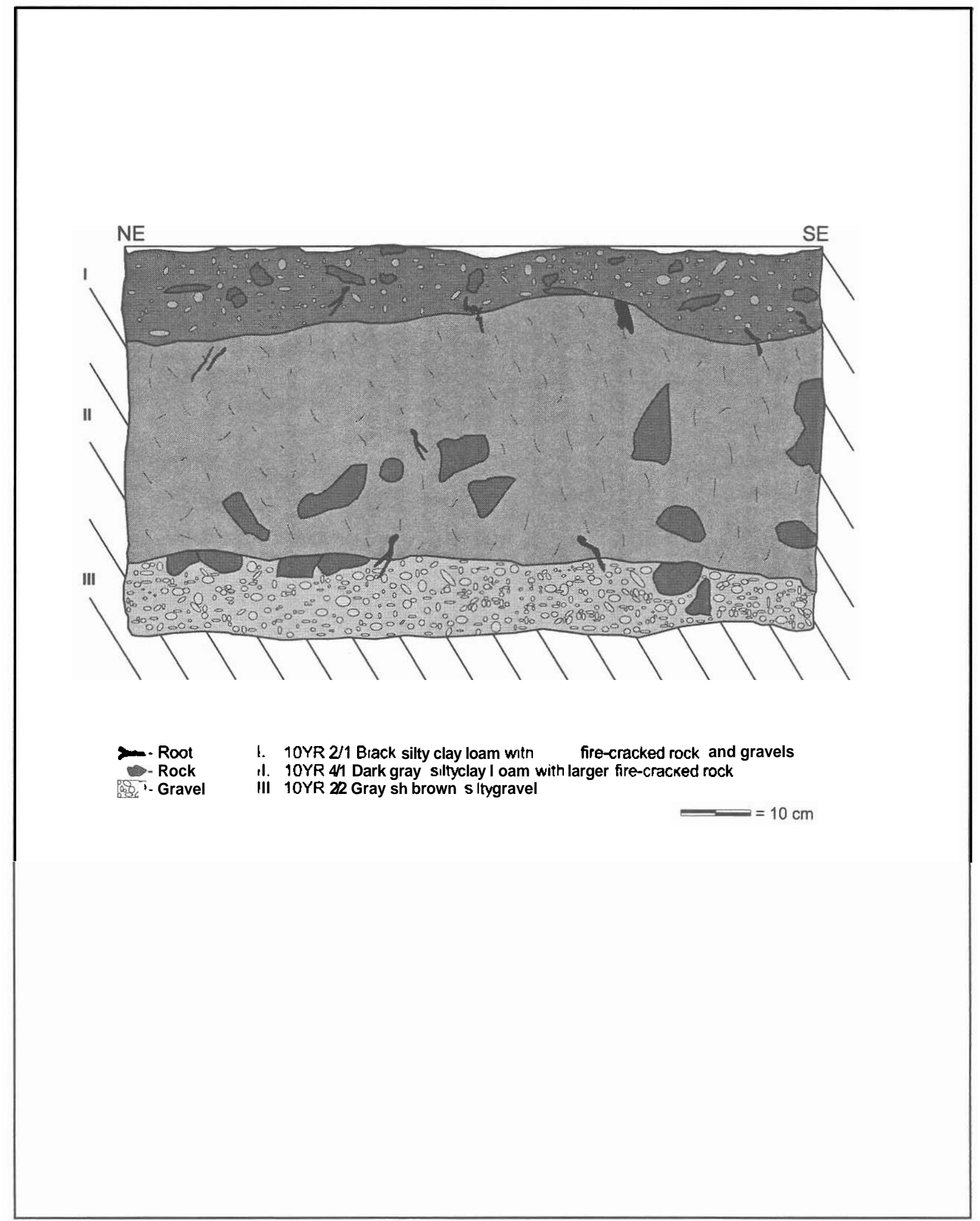

9. East wall profile of Test Unit 5 

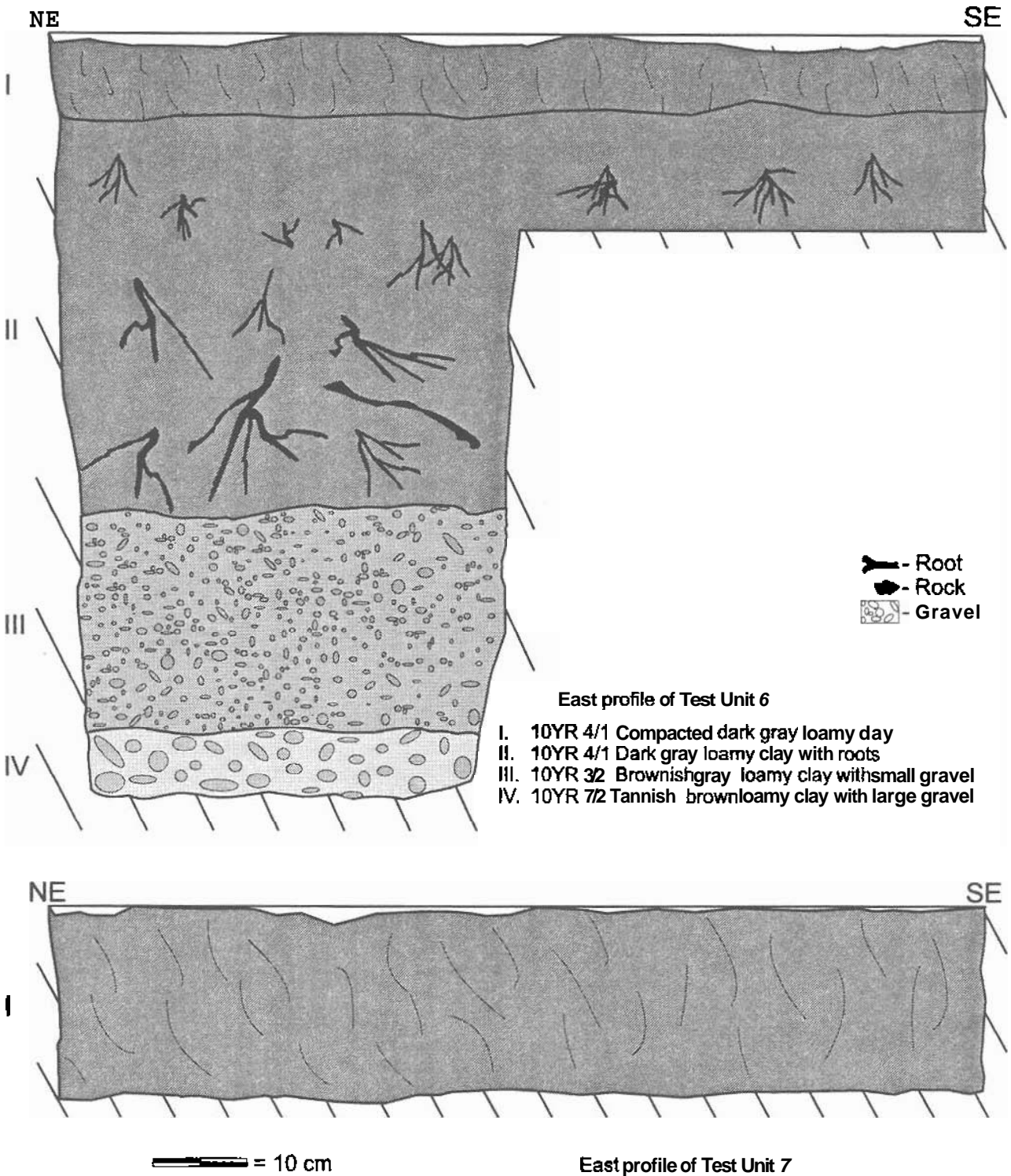

East profile of Test Unit 7

1 10YR 4/1 Dark gray loamy clay

10. East wall profile of Test Units 6 and 7. 


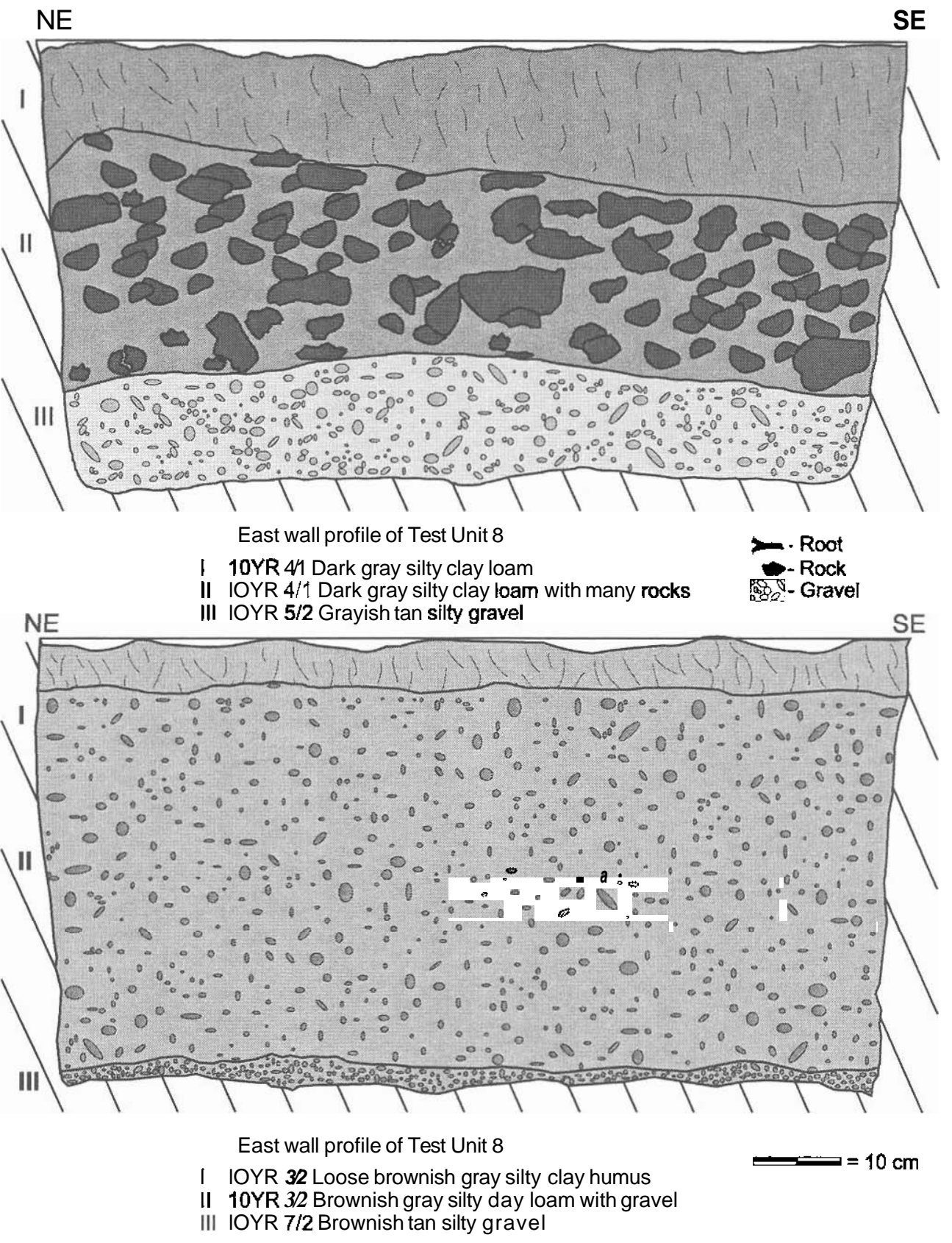

11. East wall profile of Test Units 8 and 9. 
APPENDIX B

Site Photographs 


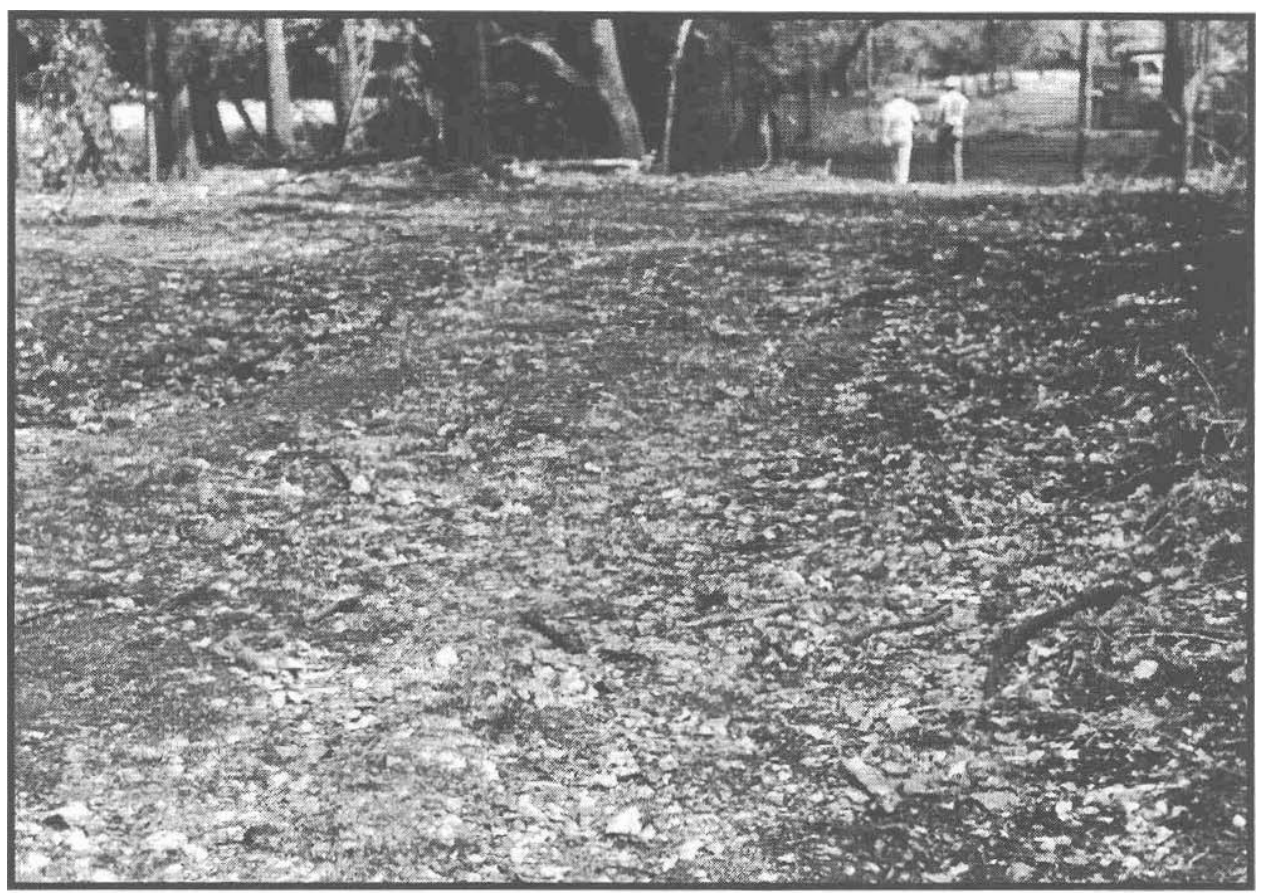

1. Overview of burned rock scatter within right-of-way before trenching.

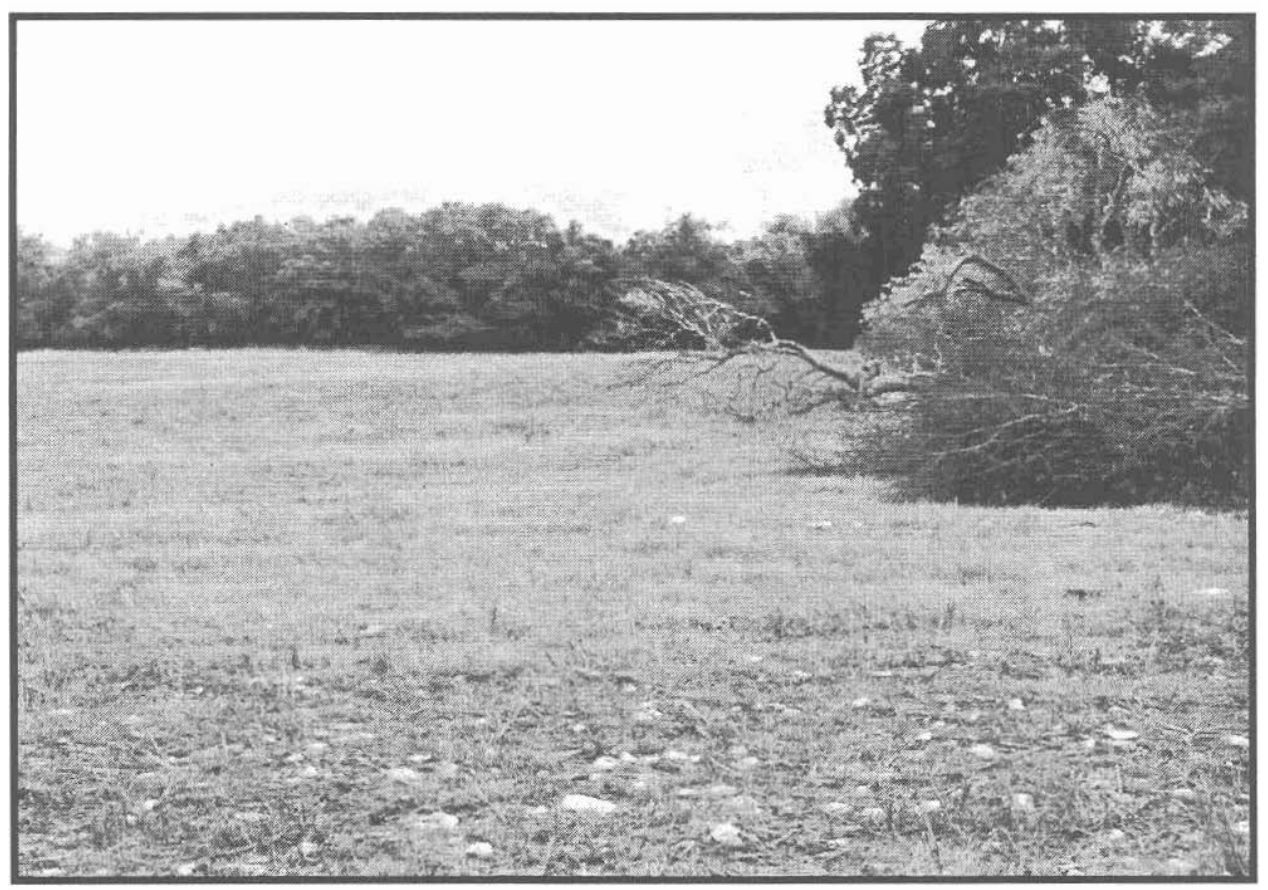

2. Site area of 41 WM543 outside the FM 734 right-of-way. 


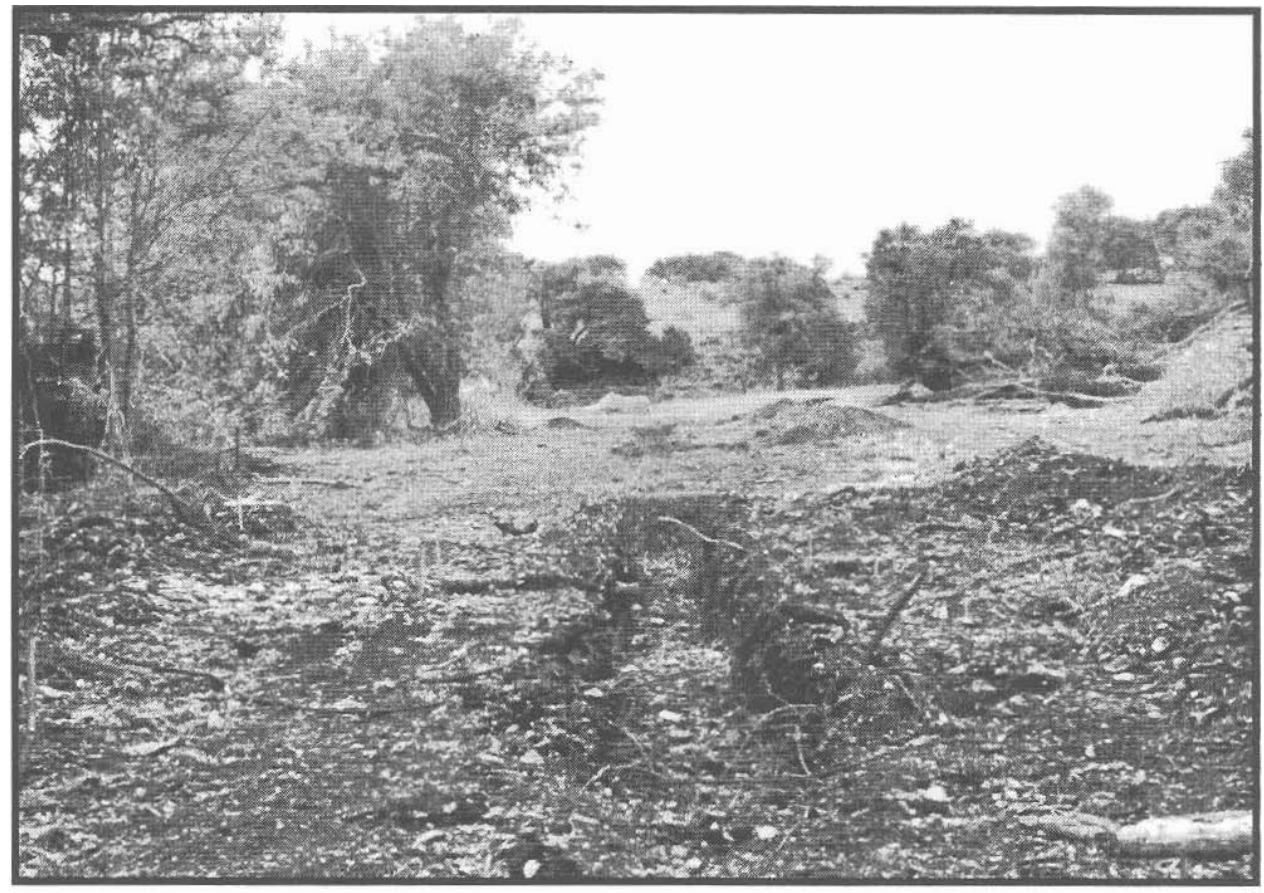

3. Beginning trenching at Backhoe Trench A looking south. 


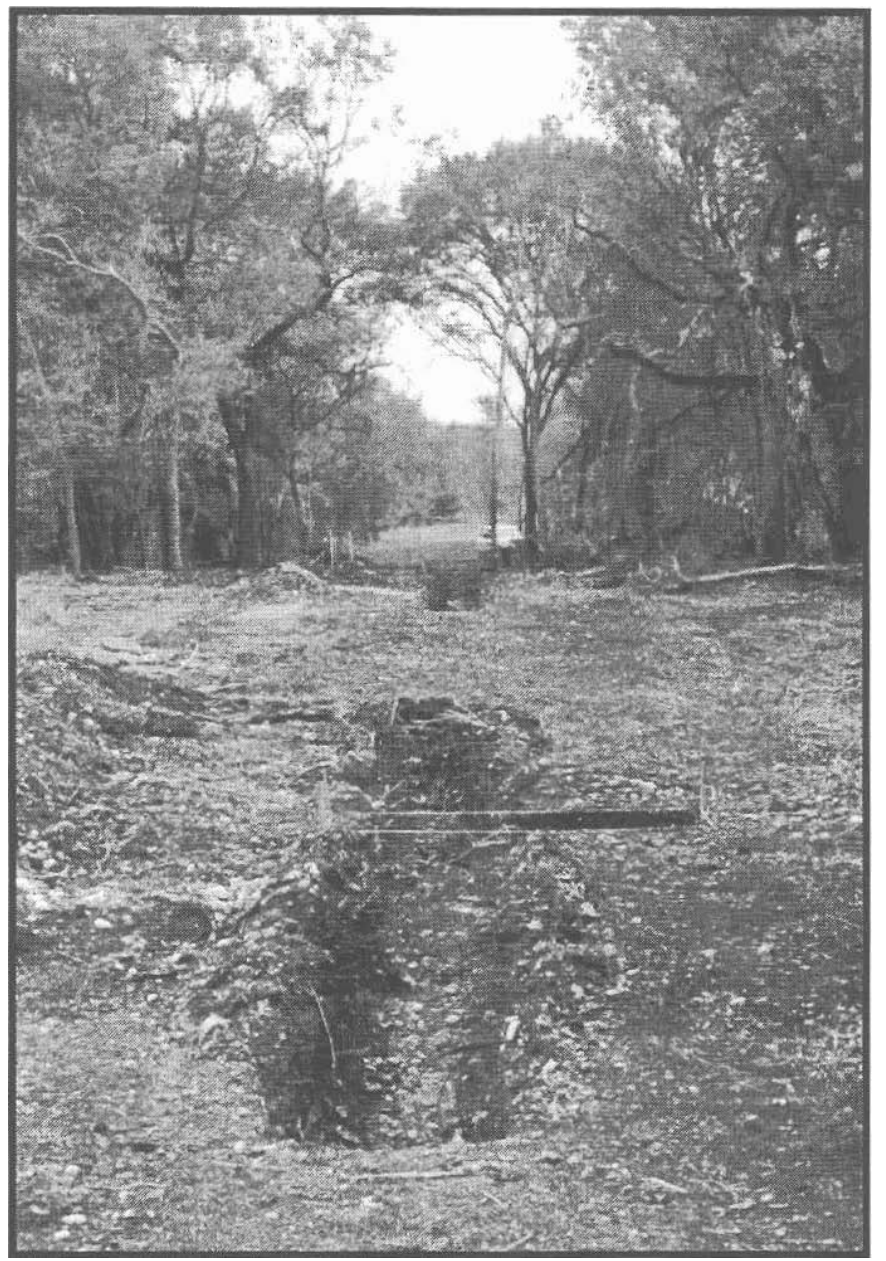

4. Sitearea 41WM543 showing Backhoe T rench B ( foreground) and $A$ (background). looking north. 


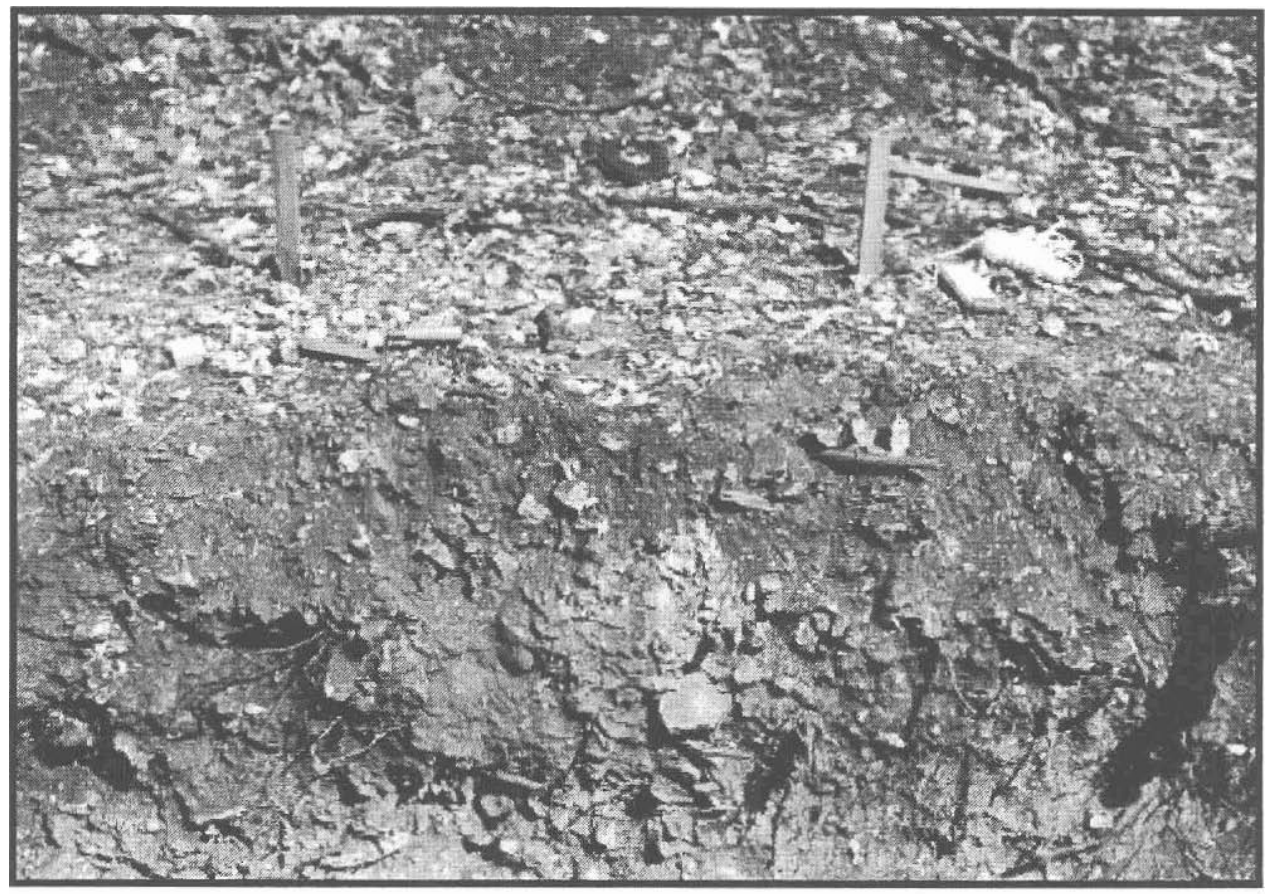

5. East wall profile of I3acklioc Trench A. showing ashy concentrationt.

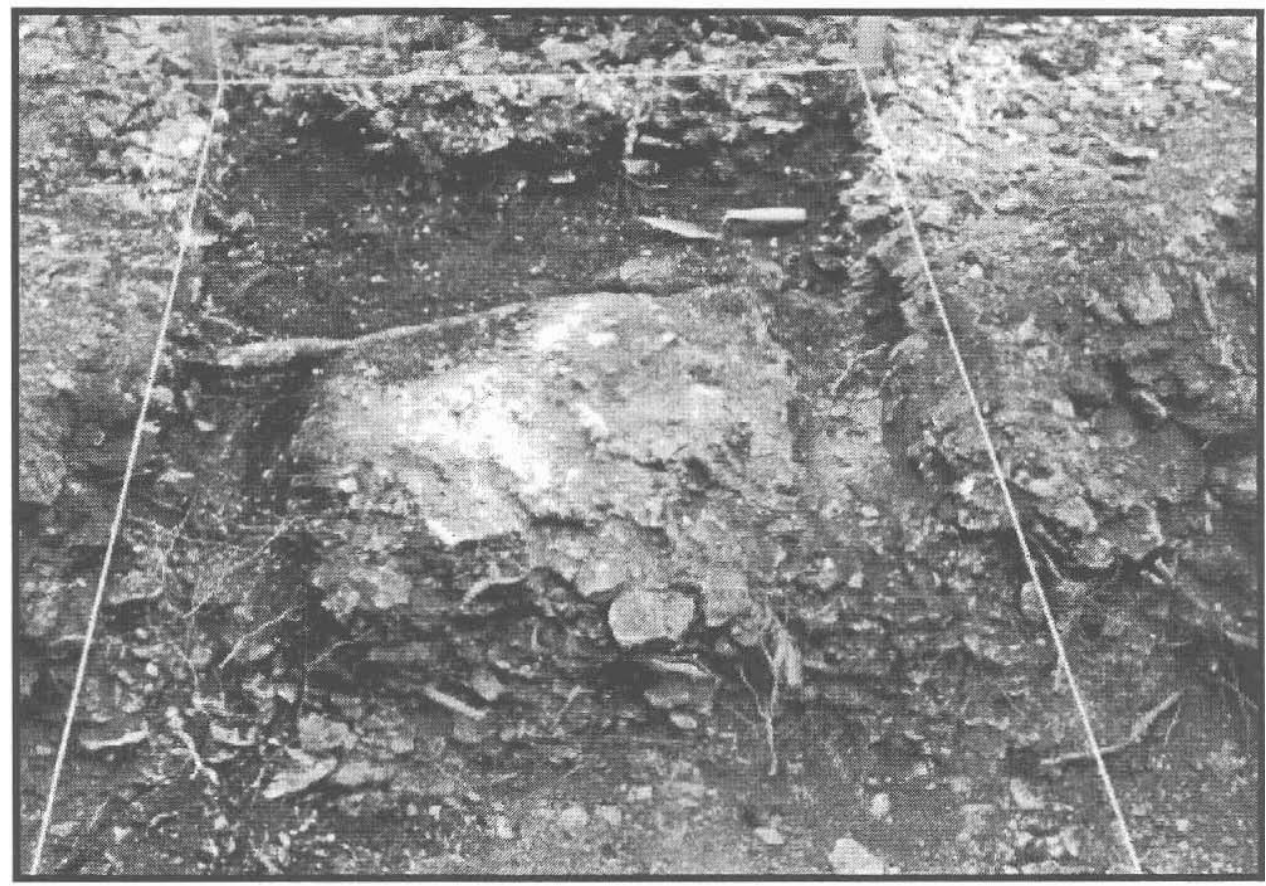

6. Test Unit 3 with ashy concentration pedestalled. 


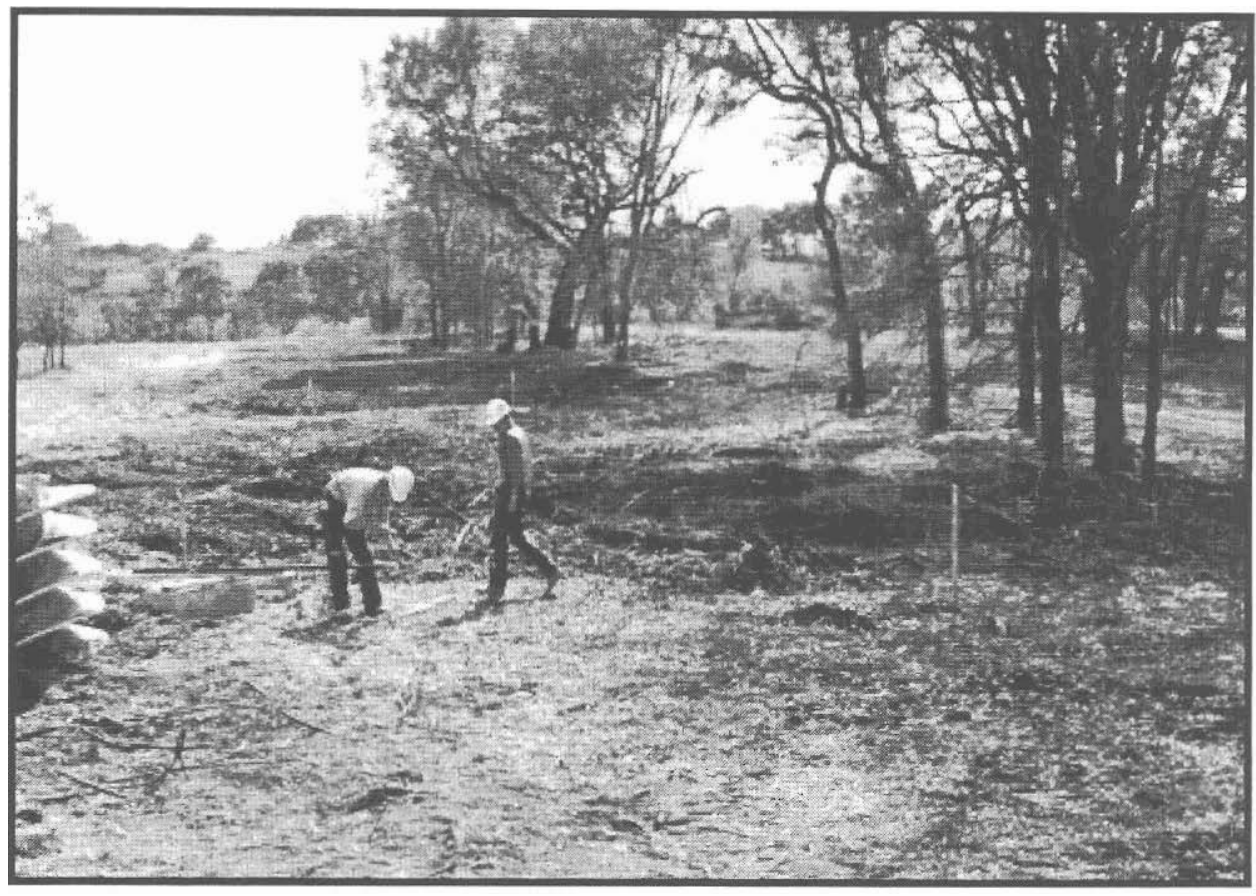

7. Beginning drill shafts looking south.

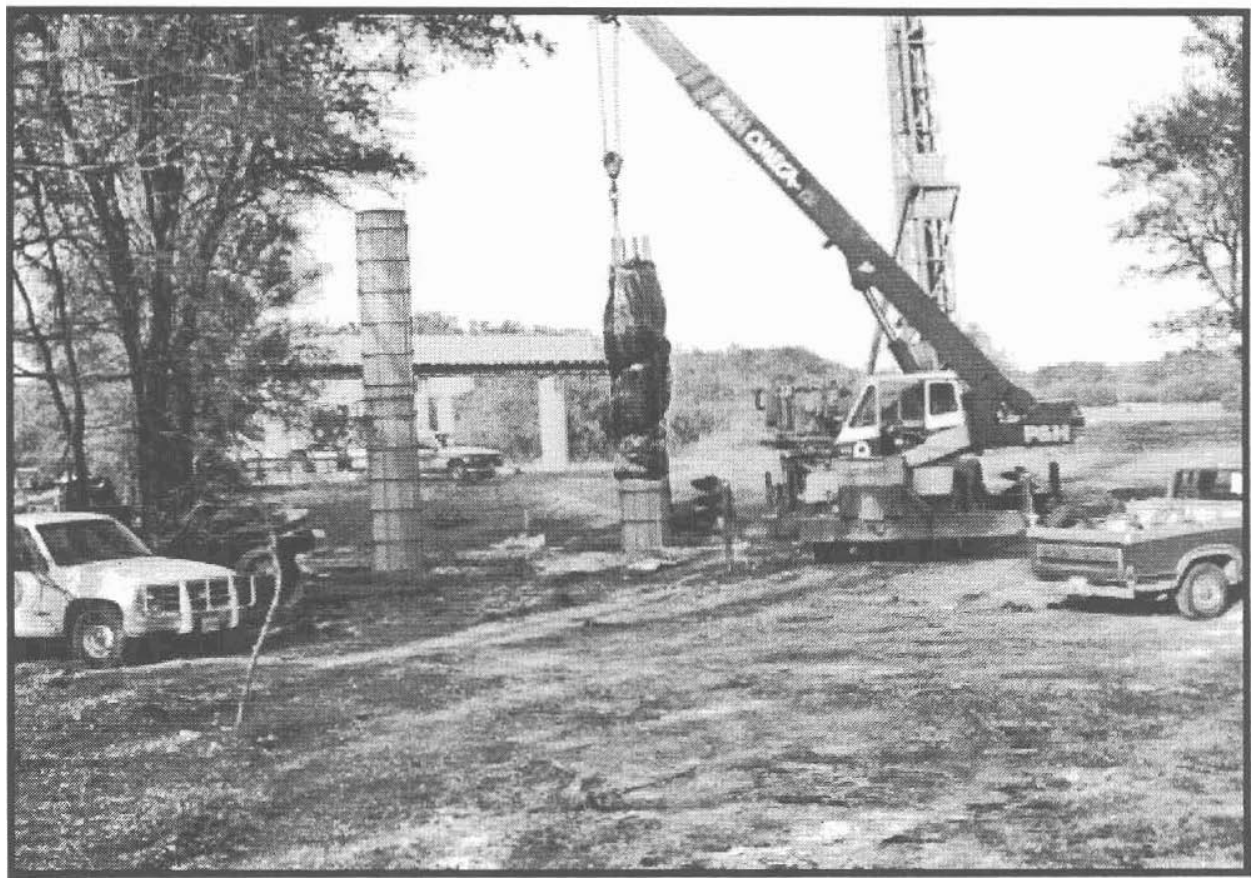

8. Construction of piers for hidge bents. looking notth. 